\title{
A Methodology for Identifying Materials Constraints to Implementation of Solar Energy Technologies
}

July 1978

Prepared for the U.S. Department of Energy under Contract EY-76-C-06-1830

Pacific Northwest Laboratory Operated for the U.S. Department of Energy by

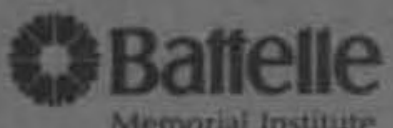


NOTICE

This report was prepared as an account of work sponsored by the Unired trates Government, Neither the United States nor the Deiartinent of Energy, nor any of their employees, nor any of theit cantractors. subconiractors, or their eraployees, makes any warranty. expreas or implindi or assumes any legal lialsilicy of responsibility for the accuracy, completeness or usefuiness of any informution, apparatus, product or process disclosed, or represents that its use would not iniringe privately owned tights.

The views, opinions and canclusions conrained in this report are those of the contractor and do not necessartly represent those of the United States Govetnment or the United States Department of Energy.

\author{
PACIFIC NORTHWEST LABORATORY \\ aperated by \\ BATTELLE \\ for the \\ UNITED STATES DEPARTMENT OF ENERCY \\ Under Contract EY-76-C-06-1830
}

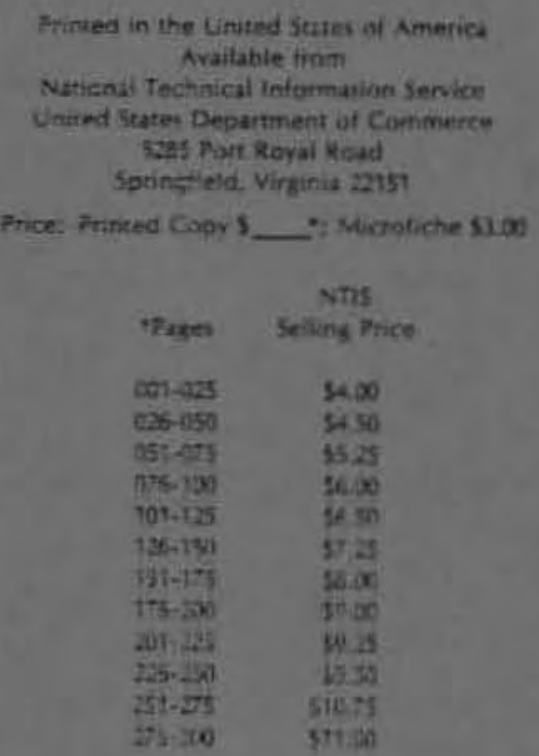


PNL -2711

UC-63

\section{9}

\section{A METHODOLOGY FOR IDENTIFYING MATERIALS CONSTRAINTS TO IMPLEMENTATION OF SOLAR ENERGY TECHNOLOGIES}
J. W. Litchfield
R. L. Watts
W. E. Gurwel1
J. N. Hartley
C. H. Bloomster

Ju1y 1978

Prepared for the U.S. Department of Energy under Contract EY-76-C-06-1830

Pacific Northwest Laboratory

Richland, Washington 99352 


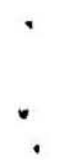

, 
TO DISTRIBUTION:

The need to logically understand the potential impacts of an energy technologies material requirements on the reserves and resources of that material as well as on the processing capability that exists to extract and produce the material is paramount to successful commercialization of a technology. Based upon this recognized need, a methodology has been developed by which one can characterize the technology (describe its material requirements for energy system components, subsystems, or technologies) and based upon forecasts for implementation of the technology determine the materials and processing impacts as a function of time.

This methodology pinpoints bulk and raw material requirements to produce a finished energy supply technology. The method can be used effectively in identifying those materials that may be in short supply and indicates the need for strategies to increase material processing capabilities, the availability of substitute materials and resource exploration. Thus, it can be used as a tool for estimating production requirements as well as planning materials research and development needs.

The attached report describes a computer screening methodology, linked to analytical methods to specify potential impacts. Two examples of photovoltaic systems have been used to explain the workings of the screening/analysis process.

The importance of this methodology with its data base is that it may be applied to any energy technology system or subsystem and used as a planning guide to analyze materials requirements between potentially competing technology options.

F.A. Koomanoff, Director SPS Project office Office of Energy Research Department of Energy 
$\vdots$

. 


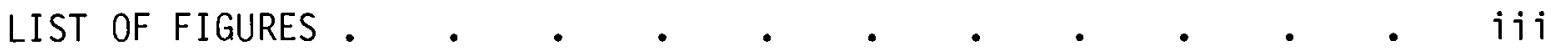

LIST OF TABLES $\quad$ •

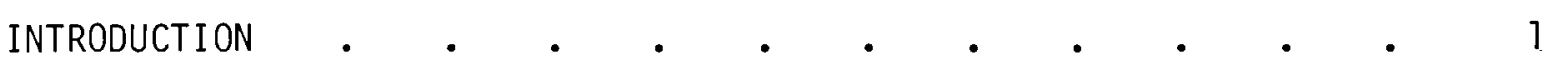

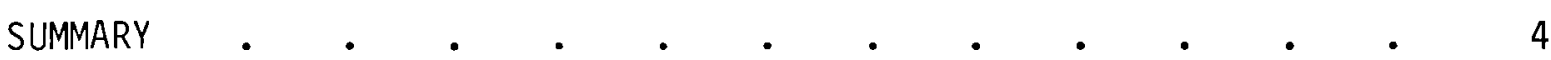

DESCRIPTION OF CRITICAL MATERIALS ASSESSMENT METHODOLOGY • • • 5

DETERMINING SOLAR MATERIALS REQUIREMENTS • • • • • • • • • 6

Solar System Characterization .

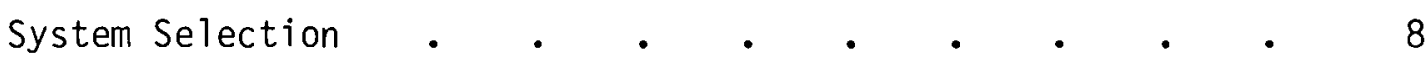

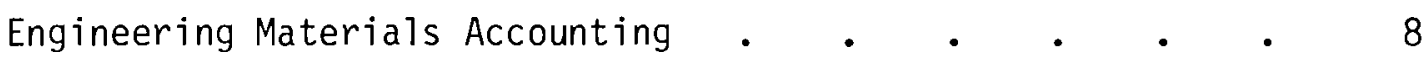

Transformation of Engineering Materials to Bulk Materials . 9

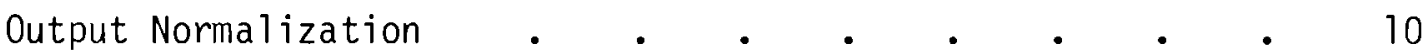

Determining Raw Materials Requirements . • • • . 11

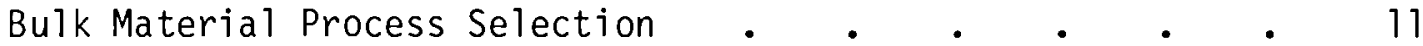

Secondary and Tertiary Materials Characterization $\quad$ • 11

Example Characterization for Copper . . . . . 13

SCREENING SOLAR MATERIALS •

Bulk Materials Screening • • • • • • • • • • 15

Raw Materials Screening • • • • • • • • • 16

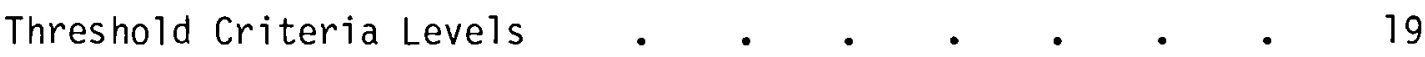

Interactive Computer System for Screening $\quad$ • $\quad . \quad$ • $\quad$ • 24

ASSESSMENT OF POTENTIAL MATERIALS PROBLEMS $\quad$ •

EXAMPLE ANALYSIS OF POTENTIAL MATERIALS PROBLEMS • • • • • • 29

Photovoltaic System Design . • • • • • • • 29

Photovoltaic Development Plans . • • • • • 30

MATERIAL SCREENING AND PROBLEM IDENTIFICATION • • • • • • 30

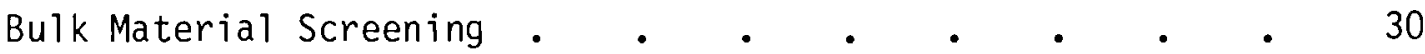

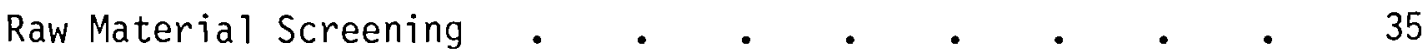

ASSESSMENT OF MATERIALS PROBLEMS $\quad$ •

Aluminum - Bulk Material Concerns . $\quad . \quad$ • . $\quad$ • 39

Aluminum - Raw Material Concerns - Bauxite . . . . 40

Antimony - Bulk and Raw Material Concerns . $\quad \cdot \quad$. 41

Copper - Bulk Material Concerns . • • • • • • • 42 


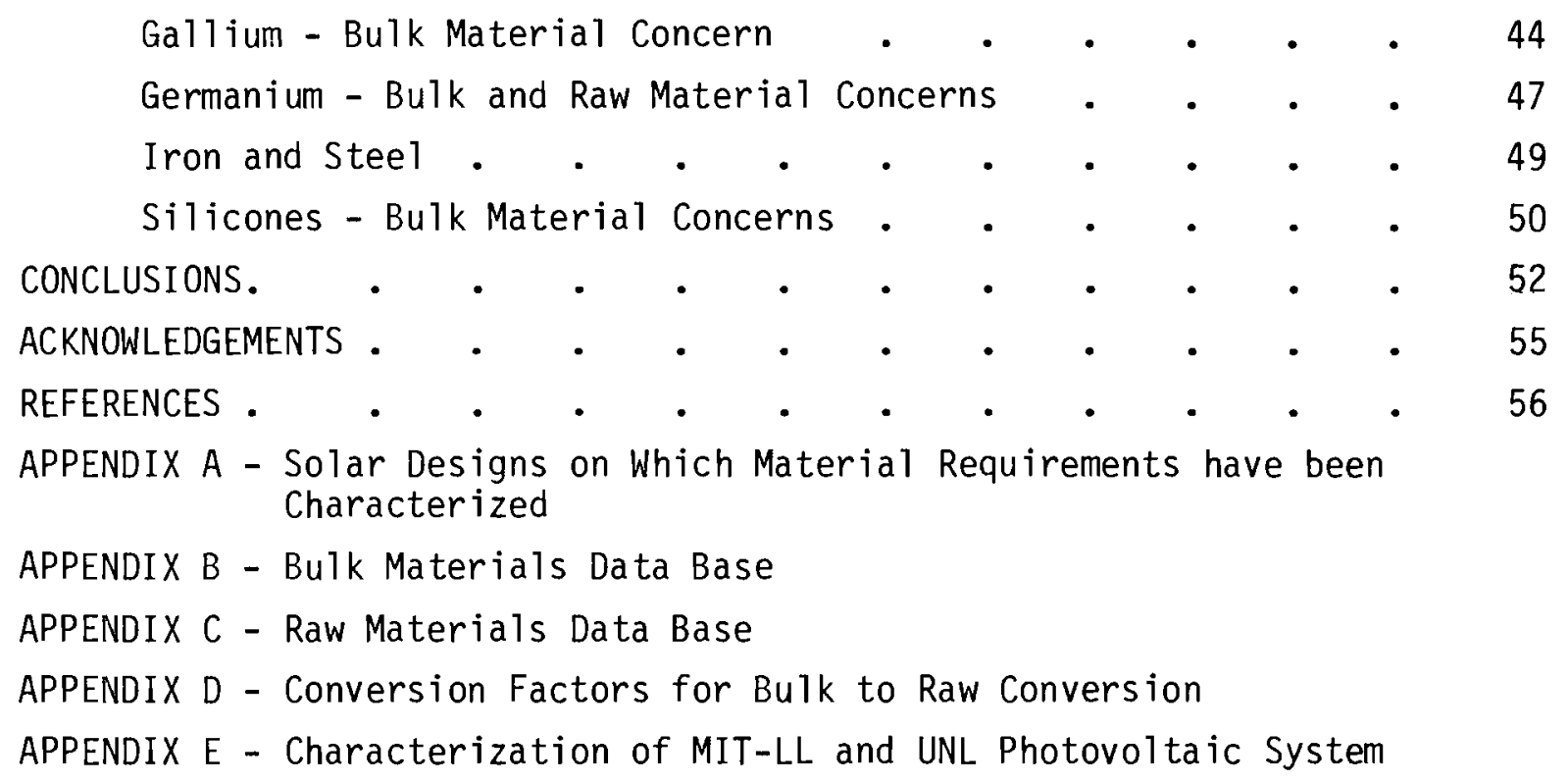




\section{LIST OF FIGURES}

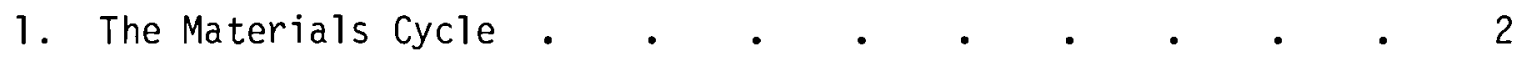

2. Installed Peak Capacity for Photovoltaic Development Plan . 3

3. Flow Chart of Materials Assessment Methodology $\quad$ • $\quad$ e 7

4. Process Characterization . • • • • • • • • . 12

5. Example of Procedures to Determine Raw Material Requirements . 14

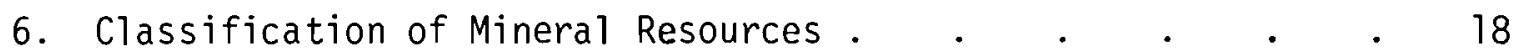

7. Interactive Screering System . . . . . . . . 26

8. Assessment of Potential Materials Problems . . . 28

9. Massachusetts Institute of Technology - Lincoln Laboratory and University of Nebraska at Lincoln Photovoltaic System at Mead,

10. Price History and Future Price Estimates for Bulk Aluminun in

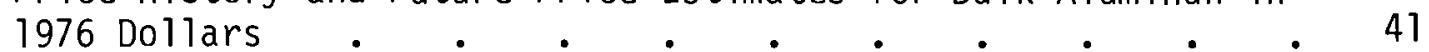

11. Copper Prices and Grade of Copper Ore . . . . . 43

12. Productivity in Copper Industry, 1947-1975 . . . . 43

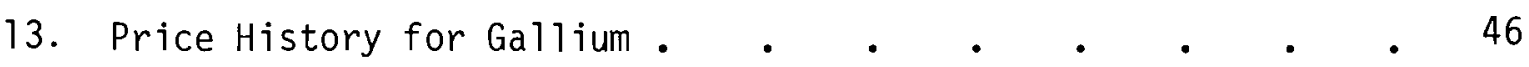

14. Price History and Future Price Outlook for Germanium . 49

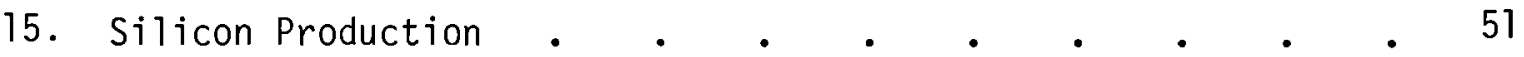

16. Price History and Future Price Forecast for Silicones • 52

\section{LIST OF TABLES}

1. Important Factors for Screening Bulk Materials . 17

2. Important Factors for Screening Raw Materials • • • 20

3. Bulk Material Threshold Criteria . • . . . . . 21

4. Raw Material Threshold Criteria . • • • • . 22

5. Summary of Materials Contained in the MIT-LL and UNL Photovoltaic System at Mead, Nebraska . . . . . . . . . 31

6. Bulk Material Requirements for Silicon N/P Single Crystal - 33

7. Bulk Material Requirements for GaAs-MIS Thin Film Cell • 34

8. Potential Bulk Materials Problems . • • . . . . 35

9. Raw Material Requirements for Silicon N/P Single Crystal. 36

10. Raw Material Requirements for GaAs-MIS Thin Film Cell • • 37 
11. Raw Material Screening Results for the Two Photovoltaic Designs

12. Overview of Significant Materials Problems for the Silicon N/P Single Crystal and GaAs-MIS Designs . • • • • • 


\section{A METHODOLOGY FOR IDENTIFYING MATERIALS CONSTRAINTS TO IMPLEMENTATION OF SOLAR ENERGY TECHNOLOGIES}

\section{INTRODUCTION}

The expanding implementation of solar energy technology will involve the use of large amounts of common construction materials and, in some cases, relatively rare materials. Heavy use of such materials could produce upward pressures on the future cost of solar energy and/or limit the rate at which solar energy devices could be produced and placed in the energy market. Thus, the Environmental Research Assessment Branch, Division of Solar Energy, Department of Energy (DOE) initiated this study with the objective of developing a methodology for identifying those specific materials, processes, and resources that can potentially hinder the implementation of solar technologies. Using this method as a tool for early identification of potential materials problems during the solar research and development process allows for development and implementation of strategies for mitigating these materials problems; e.g., design modifications, industrial research and expansion, and resource exploration.

The materials cycle shown in Figure 1 provides the basis for the materials assessment methodology presented in this report. This conceptual materials cycle illustrates the flow of materials from their natural state in the earth's crust as ores or raw materials toward their use as final products and devices. The three major materials states shown are raw materials, bulk materials, and engineering materials (alloys). Although production increases in certain steps of this materials cycle could be achieved rather quickly (1-2 years), increasing production of bulk and raw materials would require significant lead time (5-20 years). For this reason, the bulk materials necessary to produce engineering materials for constructing solar energy systems and the raw materials necessary to produce the required bulk materials have the greatest potential impact on solar growth.

The materials assessment methodology involves two basic activities. First, a screening process is used to identify the bulk and raw materials 


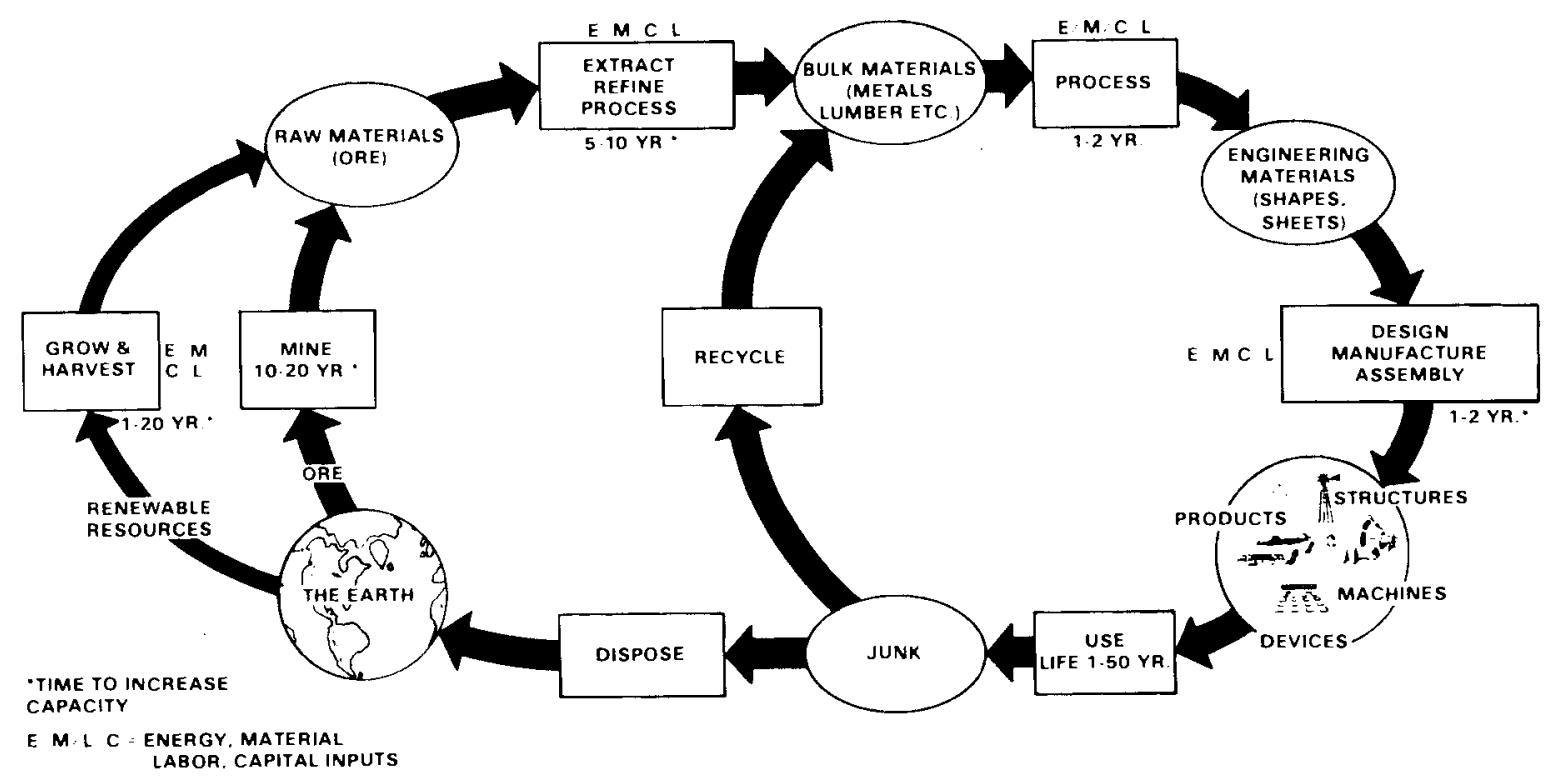

FIGURE 1. The Materials Cycle

that appear to be significant problems. An interactive computer system is used to perform this screening process. Second, a more detailed material assessment is performed on each material identified through screening to determine the severity of the material's problems.

The assessment of future solar materials is performed over the time frame when solar technologies will be emerging to compete with existing energy sources; i.e., the years 1977-2000. The process of estimating the materials needs of solar technologies over this time period involves the combination of a "solar development plan" with estimates of the materials requirements of specific solar designs. The solar development plan involves a forecast, for each design, of the date of commercial introduction and the total amount of peak energy production capacity in the year 2000. These two estimates are used to determine an exponential growth rate based on the natural constant $e$. The form of this equation allows for an ever increasing number of Giga-Watts electric (GWe) installed in each year. This growth function is frequently used to estimate the rate of introduction of new technologies. The solar development plans used for 
the examples discussed later in this report are based on a 50 GWe goal of peak power production in 2000 and an initial commercial introduction date in 1985. The resulting installed peak capacity in each year is shown in Figure 2.

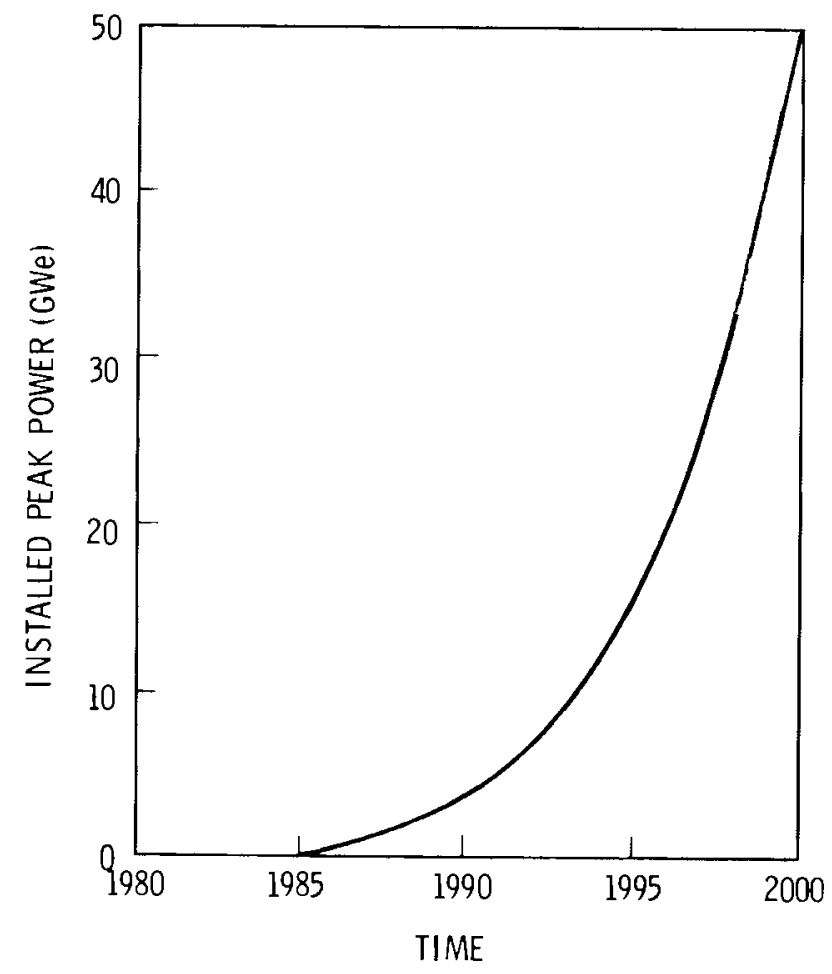

FIGURE 2. Installed Peak Capacity for Photovoltaic Development Plan

Subsequent sections of this report describe a comprehensive materials assessment methodology and demonstrate its application using an example photovoltaic development plan. The methodology is applicable to any of the following solar technologies.

- Solar Heating \& Cooling of Buildings - Solar Thermal Conversion

- Agricultural and Process Heat

- Solar Photovoltaic Conversion

- Ocean Thermal Energy Conversion

- Wind Conversion

- Fuels from Biomass

- Space Satellite Power Systems 
To date, development of the methodology and its associated data base has emphasized solar heating and cooling of buildings, agricultural and process heat, and photovoltaic conversion technologies.

\section{SUMMARY}

A materials assessment methodology for identifying specific critical material requirements that could hinder the implementation of solar energy has been developed and demonstrated. The methodology involves an initial screening process, followed by a more detailed materials assessment. The screening portion of the methodology utilized specific screening factors and associated criteria to help identify potential material problems. The screening factors have been effective in identifying significant material problems worthy of subsequent detailed assessment.

The screening process has been computerized on a user-interactive system which allows the user to select a specific solar development plan between the years 1977-2000, a solar design or mix of designs which will accomplish the solar development plan, and variable decision criteria for each screening factor. In this way, the user can rapidly evaluate the material and resource requirements of various solar development scenarios and, in turn, the potential impact of these requirements on the technical and economic feasibility of alternative designs.

A detailed materials assessment is required on potential materials problems which are identified as a result of the screening process. The detailed assessment considers such materials concerns and constraints as: process and production constraints, reserve and resource limitations, lack of alternative supply sources, geopolitical problems, environmental and energy concerns, time constraints, and economic constraints. Evaluation of these issues can serve to more specifically identify those material problems of greatest concern and significance to a specific solar technology. This information can then be used to develop mitigation strategies for relieving the material problems such as design changes, R\&D programs for material supply, or material management programs by the government. 
The computerized screening process requires an extensive data base, which includes:

- The engineering and bulk material requirements for various solar technologies and systems; and

- Basic data on bulk and raw material availability throughout the world.

Data for 55 bulk and 53 raw materials are currently available on the data base. These materials are required in the example photovoltaic systems. One photovoltaic system and thirteen photovoltaic cells, ten solar heating and cooling systems, and two agricultural and industrial process heat systems have been characterized to define their engineering and bulk material requirements. Only the photovoltaic system with two alternative cells have been fully implemented on the interactive computer system; the other systems are currently being added to the data base. Other solar systems can be characterized and their materials requirements added to the data base allowing for subsequent computerized screening. The methodology can be applied in concept to any solar system which is adequately developed so that it's material requirements can ge characterized.

The materials assessment methodology has been demonstrated for a photovoltaic system utilizing two different cell designs. The screening process is performed for the various bulk and raw materials involved in this photovoltaic system and subsequent detailed assessments are performed for those materials which appear to be significant constraints.

\section{DESCRIPTION OF CRITICAL MATERIALS ASSESSMENT METHODOLOGY}

The technological environment surrounding the development and implementation of solar energy conversion systems is rapidly changing because solar technologies are continually evolving. The materials requirements for the various raw and bulk materials are, therefore, continually changing also. It was concluded that a structured methodology was required to identify materials problems of greatest concern. This methodology must be flexible enough to respond to changes in the solar designs and yet provide 
clear documentation of the process by which potential problem materials are identified.

The quantity of materials needed to implement solar energy conversion systems is dependent upon many factors including:

- Solar Design Characteristics,

- Solar Growth Rates, and

- Material Production Processes.

In addition, the significance of materials needs can only be determined by an evaluation of many related production factors such as:

- Resource Availability,

- Production Capacity,

- Materials Cost, and

- Materials Production Processes.

In response to these concerns, the methodology diagramed in Figure 3 was developed. The methodology combines estimates of the materials requirements with a development plan for a specific solar design. The resulting bulk materials requirements are transformed as a result of materials process analysis to raw materials requirements. These two groups of materials are then screened to assess the major concerns with materials usage and to identify potential materials problems. A detailed assessment of materials problems is then performed to evaluate the severity of each material problem and to identify alternative strategies for managing a materials usage.

\section{DETERMINING SOLAR MATERIALS REQUIREMENTS}

Solar System Characterization - The objective of solar system characterization is to estimate the engineering and bulk materials necessary to construct complete solar conversion systems. In achieving this objective, it is necessary to select "typical" solar designs which are representative 


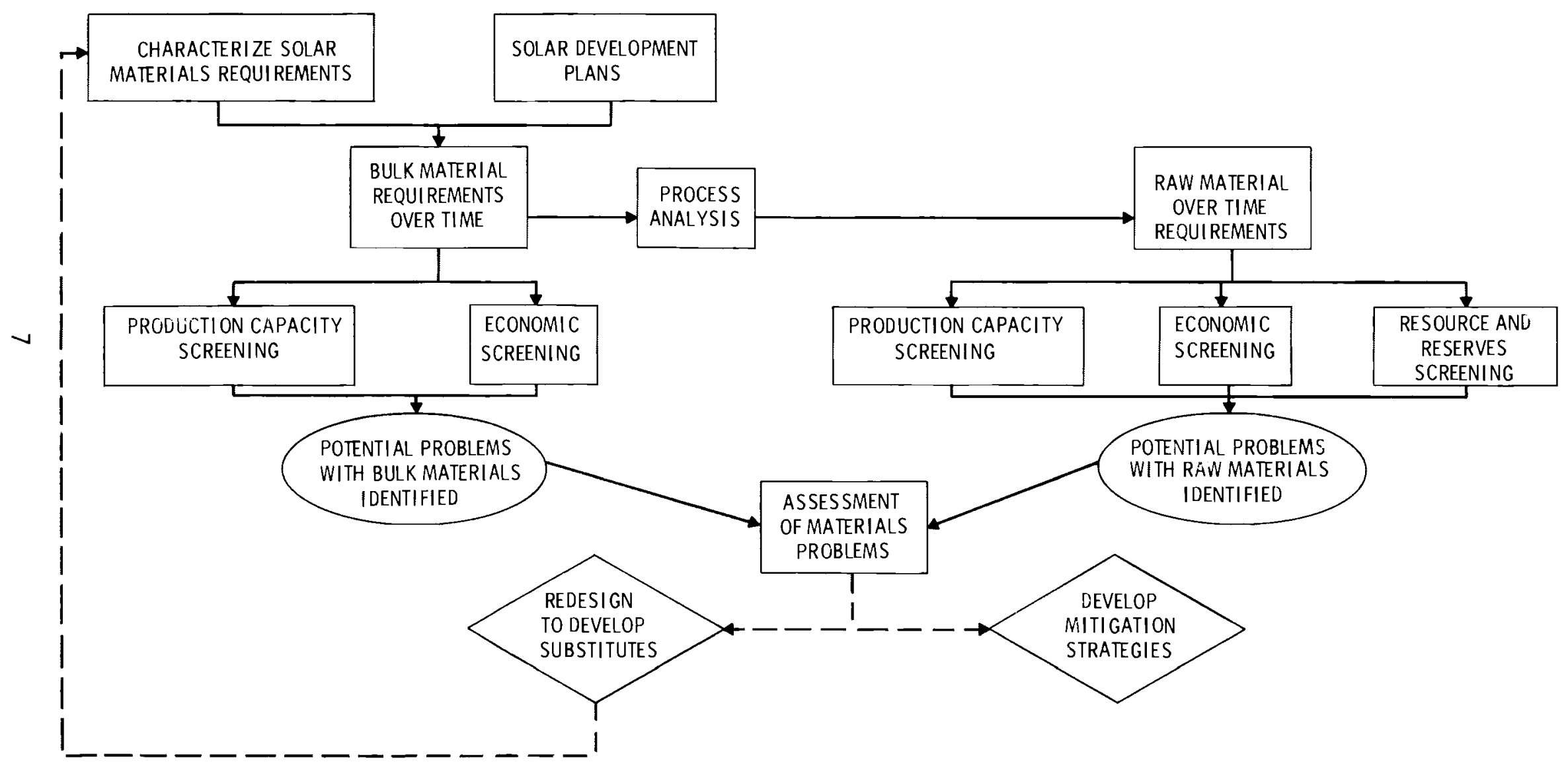

FIGURE 3. Flow Chart of Materials Assessment Methodology 
of each of the solar technologies. Each design is broken down into functional components on which engineering materials needs are estimated. These functional components comprise the energy conversion system and allow for rapidly testing the effects of substituting redesigned components. Example functional components will be discussed in more detail later in this report. Following identification of engineering materials requirements, the engineering materials are transformed into their bulk material components.

System Selection - For each solar energy conversion technology a number of reference systems can be identified. In this study two reference systems were chosen with the aid of DOE staff. Actual system designs are preferable to components of systems to assure compatability between design characteristics of each component. Where possible, actual installations are selected as reference systems. A detailed list of engineering material requirements is then established for the functional components of each system.

Engineering Materials Accounting - Because of the dynamic environment in which solar designs exist, it was necessary to develop a structured approach to materials accounting. The approach chosen involves identification of functional components of all solar systems. Because of the basic similarities among solar systems, two major categories of functional components, Energy System and Plant Support Systems, have been identified. Each of these major categories are comprised of a set of functional components.

The energy system category includes operations that are performed on the input solar energy during its transformation to a more useful form. The plant support system category includes all functions not dealing directly with the manipulation of the power being collected. Examples of the subsystems within energy system operations are:

- Energy Concentrator

- Energy Collector

- Energy Transfer

- Energy Converter
- Energy Storage

- Energy Conditioner

- Energy System Controller 
Examples of plant support subsystems are:

- Personnel Support Facilities

- Plant Utilities

- Plant Operation and Maintenance

- Plant Installation

Further functional detail can be provided by identifying the distinct components of the subsystems that make up the energy and plant support systems. For example, the energy collector is composed of the following functional components:

- Glazing

- Absorber

- Energy Transport

- Insulation

- Reflector
- Frame

- Seals

- Supports

- Miscellaneous

Characterizing materials requirements using these functional components allows for easily updating a solar design to reflect specific design changes in one or more components. The engineering materials requirements to construct each of the components in the solar system are estimated and documented using this materials accounting hierarchy. This provides the basis for determining the engineering material requirements of a specified solar system.

Information on engineering materials requirements is obtained from the component designer or manufacturer and typically is founded on construction drawings with bills of materials. In some cases, component design drawings are not available or the component design is proprietory. In those cases schematics, component descriptions, and sales literature followed by requests for additional information from the manufacturer have been an adequate substitute for the detailed design drawings.

Transformation of Engineering Materials to Bulk Materials - The detailed accounting of the materials contained in the components of a solar system 
is aggregated by material to identify the total amount of each engineering material used. It is necessary that we convert these engineering materials requirements into bulk materials requirements. This is accomplished by a transformation matrix that converts an engineering material into its constitutent bulk materials. The coefficients in this conversion matrix were based on the actual proportions of each bulk material present in each engineering material. For example, electrical grade 60-40 solder actually contains $63 \%$ tin and $37 \%$ lead.

While bulk materials used directly by solar technologies are identified during the solar system characterization as previously described, additional bulk materials may be used as process inputs in the production of other bulk materials required by the solar designs. These secondary bulk materials are identified during the process characterization phase, described later in this report, and are also included in the assessment methodology.

Output Normalization - Each solar system has associated with it a design energy output as estimated by the designers. Materials requirements necessary to achieve a specified energy output are attained by scaling using multiples of the designed system. For instance, the materials requirements for $100 \mathrm{Kw}$ of photovoltaic power are assumed to be four times those for a single $25 \mathrm{Kw}$ photovoltaic system. Estimates of materials requirements developed in this way are sufficiently accurate for purposes of materials problems assessment.

The peak output of most solar systems is given as part of the system design, except for the residential heating, cooling and hot water systems. In these cases, computer codes can be used to determine the peak energy output of each system to be studied.

Since the energy output of solar energy systems is directly dependent on insolation and weather, a normative or typical United States location is assumed. 
Determining Row Materials Requirements - Solar system characterization provides the bulk materials requirements of a solar system, as described in the previous section. Process characterization is required to determine the raw material requirements for producing the bulk materials used by a solar system. The most prevalent process is selected for producing each bulk material and the raw material requirements of this process are estimated.

Bulk Material Process Selection - For each bulk material there may be several alternative production processes. Each process may use different process inputs as either raw materials or bulk materials. Only those processes in current use by industry and producing the majority of the supply of a bulk material are considered in this report.

Once a process for producing a particular bulk material has been selected, the following process inputs are estimated:

- Secondary Bulk Materials

- Raw Materials

- Energy

- Capital

- Labor

The procedure for determining raw material requirements is shown in Figure 4. All important direct inputs needed to produce a bulk material are identified. If the process input is a raw material such as an ore, further expansion is not required. However, if the input is another bulk material, the inputs to produce this bulk material must be estimated. This procedure is carried out until the most important inputs are broken down into their raw materials requirements. The quantities of raw materials used are accumulated and represent the raw materials necessary to acquire the initial bulk material.

Secondary and Tertiary Materials Characterization - The secondary and tertiary material inputs include a mixture of raw materials and bulk materials. The quantity and type of secondary bulk materials going into the production 


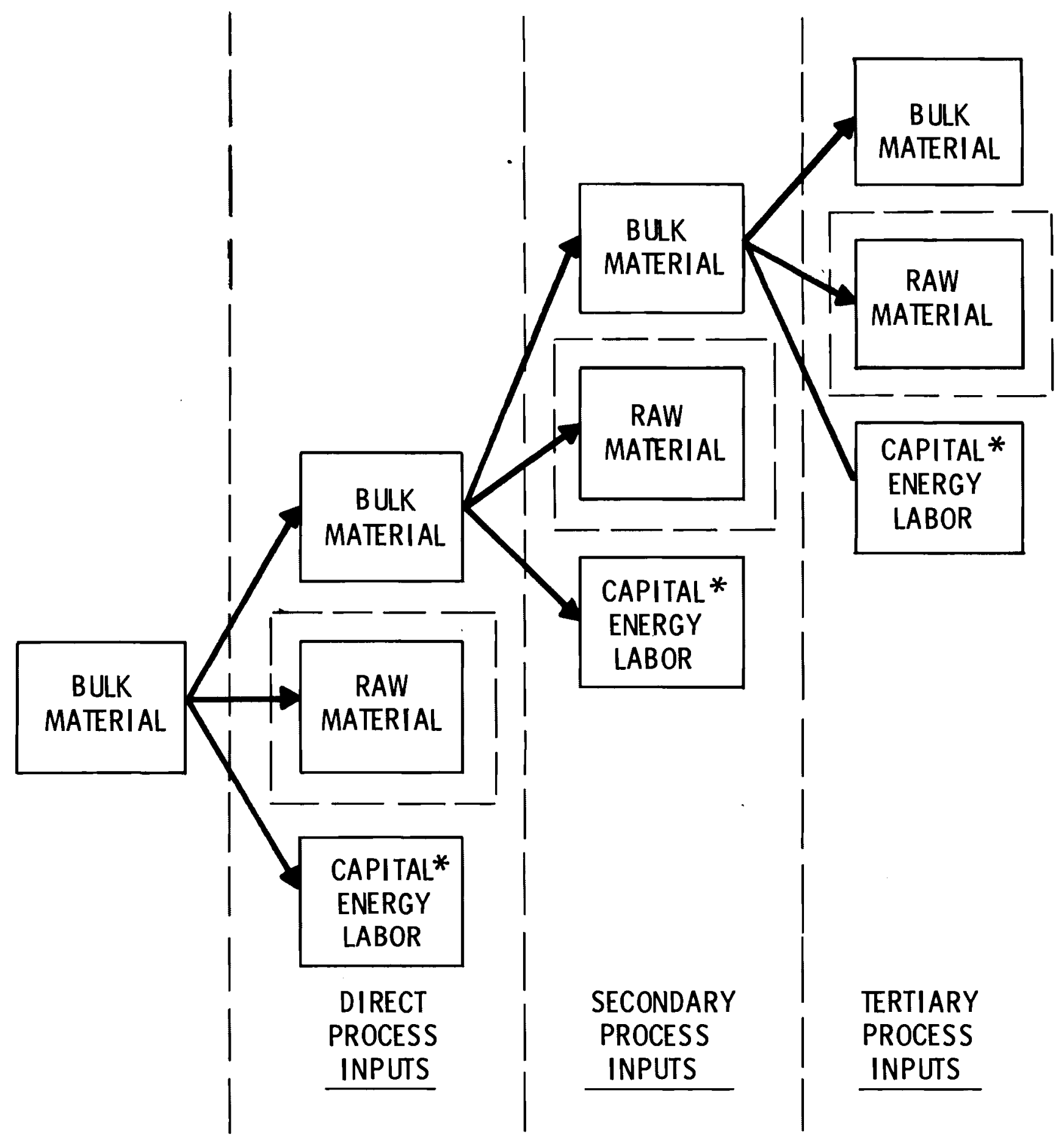

FIGURE 4. Process Characterization

*NOTE: Capital, Energy, and Labor Requirements are Estimated and Used to Identify Process Constraints for Those Materials Impacting on Solar Implementation 
of a metric ton of primary bulk material is estimated. The process of characterizing the secondary and tertiary materials is terminated when the amount of a secondary or tertiary bulk material required is small in comparison to the other materials. The exact limit used to terminate further process characterization is judgmental at best and varies depending on the material.

Excomple Characterization for Copper - To illustrate the procedure for process characterization, the bulk material copper is evaluated. Copper can be recovered by several processes; however, the most used processing system consists of mining, beneficiation, smelting, and refining. The raw materials required to produce copper, including direct, secondary, tertiary, and higher order inputs, are estimated as shown in Figure 5. The end product of this procedure provides appropriate conversion factors to convert bulk materials requirements into raw materials requirements. See Appendix D-1 for the raw materials requirements for producing one metric ton of copper.

\section{SCREENING SOLAR MATERIALS}

The solar system characterization and process characterization, as previously described, are key elements of the material assessment methodology. Specifically, these elements provided the basis for quantitative estimates of the bulk and raw materials necessary to attain a specific solar market penetration scenario using a particular solar technology. In this section we will discuss screening bulk and raw materials to separate potential problem materials from those materials that are unlikely to constrain solar implementation.

A significant number of materials are involved in the design and construction of solar technologies. Because of the large number of materials and the level of effort necessary to accomplish a detailed assessment of each material, it was necessary to develop screening that would focus material research on potential problem materials. 


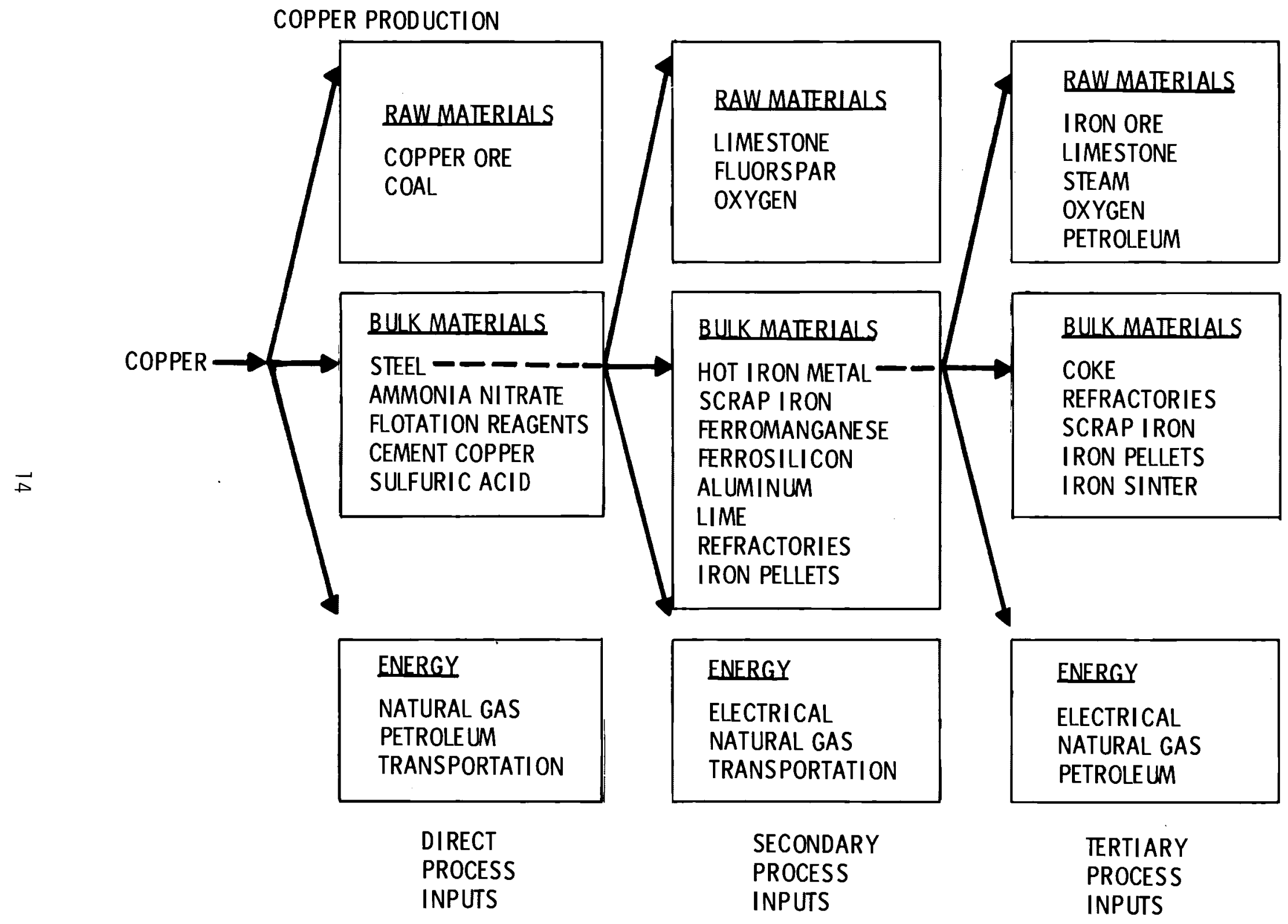

FIGURE 5. Example of Procedure to Determine Raw Material Requirements 
The screening process involves an automated procedure for comparing the identified bulk and raw materials to a series of screening factors. These factors are selected because of their relationship to the general availability and economic cost of materials. Their selection is fundamental to the degree of validity and insight obtained from materials screening. Different factors have been selected for bulk materials and raw materials to identify the broad spectrum of materials problems inherent in using large quantities of these materials.

Bulk Matexials Screening. - Two major concerns exist relative to the use of bulk materials in the development of solar technologies. The first concern is relative to the existing production capacity for bulk materials and the ability of the industries producing bulk materials to increase production sufficiently to provide for forecasted use of solar energy. Secondly, the economic feasibility of utilizing bulk materials in solar designs is of particular importance. Therefore, bulk materials are screened relative to each of these concerns.

A set of five screening factors were developed to identify materials availability problems.

- Percentage of current consumption supplied as a byproduct

- Percent of current consumption that is imported

- Percent world consumption supplied by the largest supplier country outside the U.S.

- Production growth rate necessary to meet forecasted world consumption and solar requirements

- The largest single year market share consumed by solar over the period of the solar development plan

The economic feasibility of using bulk materials in the construction of solar devices is measured in terms of the contribution to the capital cost per unit of peak power output by the solar device. This index of economic feasibility is meant to identify those bulk materials representing a significant cost when compared with the peak power generation of the solar 
systems in which they are used. To avoid the additional complexity and expense of forecasting future materials prices, the assessment of economic feasibility is based on current materials prices. It is apparent that those materials representing significant contributions to the cost of constructing solar technologies, using current materials prices, are likely to be the primary contributors to the cost of installed peak power in the future. The screening factors for bulk materials screening and their associated problem areas are shown in Table 1.

Raw Materials Screening - Following the identification of potential problems relative to using bulk materials in solar designs, it is necessary to assess the potential problems that may exist relative to the consumption of raw materials needed to produce the bulk materials. In using raw materials three major concerns have been identified. They are as follows.

- Production Capacity

- Reserves and Resources

- Economic Feasibility

Four factors have been identified relative to the production capacity concerns in the use of raw materials to produce bulk materials.

- Percent of current consumption that is imported

- Percent of world consumption supplied by the largest supplier country outside of the U.S.

- Production growth rate necessary to meet forecasted world consumption and solar requirements

- Largest single year market share consumed by solar over the period of the solar development plan

These factors are designed to identify potential problems that may exist in expanding production capacity of raw materials in order to meet the materials requirements of solar. It is important to notice that expanding production capacity of raw materials requires significant lead times and involves complex mining and exploration activities. 
TABLE 1. Important Factors for Screening BuTk Materials

\begin{tabular}{|c|c|c|}
\hline $\begin{array}{l}\text { Major } \\
\text { Concern }\end{array}$ & $\begin{array}{l}\text { Important } \\
\text { Factors }\end{array}$ & $\begin{array}{l}\text { Potential } \\
\text { Problems }\end{array}$ \\
\hline \multirow[t]{5}{*}{$\begin{array}{l}\text { Production } \\
\text { Capacity }\end{array}$} & $\begin{array}{l}\text { Percent of Current Consumption } \\
\text { Supp Tied as a By-Product }\end{array}$ & $\begin{array}{l}\text { - Materials Availability Limited } \\
\text { to Primary Material Production } \\
\text { - Increasing Capacity may not be } \\
\text { Technicaliy or Economically } \\
\text { Feasible }\end{array}$ \\
\hline & $\begin{array}{l}\text { Percent of Current Consumption } \\
\text { that is Imported }\end{array}$ & $\begin{array}{l}\text { - Uncertain Long-Term Availability } \\
\text { - Potential for Geopolitical } \\
\text { Problems } \\
\text { - Potential Transportation } \\
\text { Problems }\end{array}$ \\
\hline & $\begin{array}{l}\text { Percent of World Consumption } \\
\text { Supplied by the Largest Supplier } \\
\text { Country Outside of the U.S. }\end{array}$ & $\begin{array}{l}\text { - Potential for Cartels } \\
\text { - Possible Monopolistic or } \\
\text { 01igopolistic Markets } \\
\text { - Price Uncertainty }\end{array}$ \\
\hline & $\begin{array}{l}\text { Production Growth Rate Necessary' } \\
\text { to lleet Forecasted World Con- } \\
\text { sumption and Solar Requirements }\end{array}$ & $\begin{array}{l}\text { - Significant Time Lags to } \\
\text { Increase Production } \\
\text { - Possible Constraints From: } \\
\text { - Capital } \\
\text { - Labor } \\
\text { - Energy } \\
\text { - Raw Materials }\end{array}$ \\
\hline & $\begin{array}{l}\text { The Largest Single Year Market } \\
\text { Share Consumed by Solar Over the } \\
\text { Period of the Solar Development } \\
\text { Plan }\end{array}$ & $\begin{array}{l}\text { - Large Quantities of a Material } \\
\text { Consumed in a Year May Cause } \\
\text { Market Disequilibrium }\end{array}$ \\
\hline $\begin{array}{l}\text { Economic } \\
\text { Feasibility }\end{array}$ & $\begin{array}{l}\text { The Contributions to Capital } \\
\text { Costs per Unit of Peak Power }\end{array}$ & $\begin{array}{l}\text { - A Materials Use May be Uneco- } \\
\text { nomical when Compared with the } \\
\text { Peak Power Generation }\end{array}$ \\
\hline
\end{tabular}


Four factors were also selected to provide an assessment of potential reserves and resource problems.

- Percent of world reserves that will be consumed by the year 2000

- Percent of U.S. reserves that will be consumed by the year 2000

- Percent of world resources that will be consumed by the year 2000

- Percent of U.S. resources that will be consumed by the year 2000

These factors provide a comparison of estimated world and U.S. consumption, including the materials requirements for solar development, with current estimates of U.S. and world reserves and resources. This comparison pro vides an indicator of raw materials availability and can help to identify materials with uncertain or unknown supplies.

In discussing issues relative to reserves and resources it is important to understand the distinction made between these two terms. The relationship between reserves and resources is shown in the Mineral Resource Classification System developed jointly by the U.S. Geological Survey and the U.S. Bureau of Mines (see Figure 6).

\section{TOTAL RESOURCES}

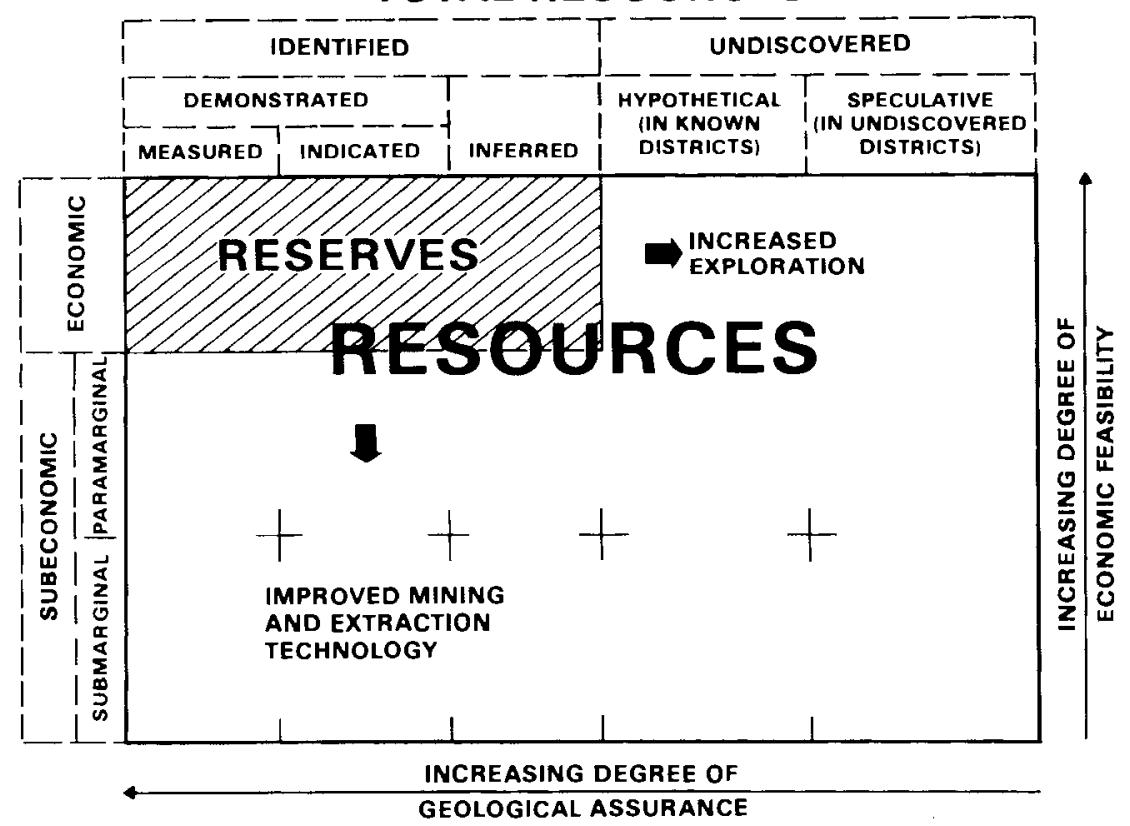

FIGURE 6. Classification of Mineral Resources $(1)$ 
This diagram illustrates changing qualities of resources in terms of increasing geologic assurance and increasing economic feasiblity. In this two-dimensional diagram reserves are represented by the shaded area. In this context reserves are defined to be that portion of the resource that is located in identified deposits and can be economically extracted given current technology and mineral prices. This diagram is a static representation of a dynamic system where the quantity of reserves is continually changing due to changes in extraction and mining technology, fluctuations in market prices, and also the extent ot exploration.

The last major concern, economic feasibility, has associated with it a factor conceptually similar to the assessment of economic feasibility used in screening bulk materials. In this assessment the current cost of each raw material will be compared with the estimated peak power of the solar system to determine the contribution of direct raw materials costs to the cost of installed solar power. This factor will identify those raw materials representing significant contributions to the cost of installed solar power and will help to identify those raw materials generating concerns relative to economic feasibility of solar technologies.

The screening factors for raw materials and their associated problem areas are shown in Table 2.

Threshold Criteria Levels - Each of the factors for screening bulk and raw materials can be measured quantitatively. This quantitative measure allows the use of threshold criteria to readily identify those materials and factors representing potential problems and requiring more detailed assessment.

The process of selecting specific threshold criteria for each factor involves a combination of both subjective judgment and known limitations inherent in using bulk and raw materials. The appropriate threshold criteria on a particular material will depend on the environment. surrounding the production and use of that material. For this reason it appears that the concept of a threshold criteria may be specific for a particular material-factor. For the examples presented later in this report, generic 


\section{TABLE 2. Important Factors for Screening Raw Materials}

\begin{tabular}{|c|c|c|}
\hline $\begin{array}{l}\text { Major } \\
\text { Concerns }\end{array}$ & $\begin{array}{l}\text { Important } \\
\text { Factors }\end{array}$ & $\begin{array}{l}\text { Potential } \\
\text { Problems }\end{array}$ \\
\hline \multirow[t]{4}{*}{$\begin{array}{l}\text { Production } \\
\text { Capacity }\end{array}$} & $\begin{array}{l}\text { Percent of Current Consumption } \\
\text { That is Imported }\end{array}$ & $\begin{array}{l}\text { - Uncertain Long-Term Availability } \\
\text { - Potential for Geopolitical } \\
\text { Problems } \\
\text { - Potential Transportation Problems }\end{array}$ \\
\hline & $\begin{array}{l}\text { Percent of World Consumption } \\
\text { Supplied by the Largest Supplier } \\
\text { Country Outside of the U.S. }\end{array}$ & $\begin{array}{l}\text { - Potential for Cartels } \\
\text { - Possibility for Monopolistic or } \\
\text { Oligopolistic Markets } \\
\text { - Price Uncertainty }\end{array}$ \\
\hline & $\begin{array}{l}\text { Production Growth Rate Necessary } \\
\text { to Meet Forecasted World Consump- } \\
\text { tion and Solar Requirements }\end{array}$ & $\begin{array}{l}\text { - Significant Time Required to } \\
\text { Increase Production } \\
\text { - Possible Constraints from: } \\
\text { Capital, Labor, Energy, \& Raw } \\
\text { Materials }\end{array}$ \\
\hline & $\begin{array}{l}\text { Largest Single Year Market Share } \\
\text { Consumed by Solar over the Period } \\
\text { of the Solar Development Plan }\end{array}$ & $\begin{array}{l}\text { - Possible Market Disequilibrium } \\
\text { and Price Instability }\end{array}$ \\
\hline \multirow[t]{4}{*}{$\begin{array}{l}\text { Reserves }(a) \\
\text { and } \\
\text { Resources }\end{array}$} & $\begin{array}{l}\text { Percent of World Reserves that } \\
\text { wi } 11 \text { be Consumed by the Year } \\
2000\end{array}$ & $\begin{array}{l}\text { - Economically Recoverable World } \\
\text { Reserves may not be Adequate } \\
\text { to Supply the Needs of Solar and } \\
\text { Prices may Increase }\end{array}$ \\
\hline & $\begin{array}{l}\text { Percent of U.S. Reserves that } \\
\text { wi11 be Consumed by the Year } \\
2000\end{array}$ & $\begin{array}{l}\text { - Economically Recoverable U.S. } \\
\text { Reserves may not be Adequate to } \\
\text { Supply the Needs of Solar and } \\
\text { Prices may Increase }\end{array}$ \\
\hline & $\begin{array}{l}\text { Percent of World Resources that } \\
\text { wi11 be Consumed by the Year } \\
2000\end{array}$ & $\begin{array}{l}\text { - Sufficient Raw Materials may not } \\
\text { be Identified, thus Requiring } \\
\text { Exploration }\end{array}$ \\
\hline & $\begin{array}{l}\text { Percent of U.S. Resources that } \\
\text { wi11 be Consumed by the Year } \\
2000\end{array}$ & $\begin{array}{l}\text { - Sufficient Domestic Resources } \\
\text { may not be Available thus } \\
\text { Requiring Increased Imports or } \\
\text { Exploration }\end{array}$ \\
\hline $\begin{array}{l}\text { Economic } \\
\text { Feasibility }\end{array}$ & $\begin{array}{l}\text { The Contribution to Capital } \\
\text { Costs of Raw Materials per Unit } \\
\text { of Peak Power }\end{array}$ & $\begin{array}{l}\text { - Current Raw Material Costs may } \\
\text { be Significant when Compared } \\
\text { with Peak Power Generation }\end{array}$ \\
\hline
\end{tabular}

(a) See Figure 6 for a definition of reserves and resources. 
threshold criteria were derived on each factor and are meant to be applied to all bulk and raw materials used in the examples.

Because of the subjective aspects of threshold criteria, we have designed the process of screening to allow for parametric input of the desired threshold criteria limits. This provides users of this materials screen with the capability to change threshold criteria values and observe the effects on the identification of materials problems.

For the purpose of the examples presented in this report we have established the threshold criteria values shown in Table 3 . For each factor a specific quantitative threshold limit was chosen and the reasons these values were selected are also shown in Table 3 .

TABLE 3. Bulk Material Threshold Criteria

Factor

Percent of normal supply derived as a by-product

Percent of current consumption that is imported.
Value Selected

$50 \%$

$50 \%$

Percent of wor id consumption supplied by the largest suppiier country outside of the U.S.
$35 \%$

Price leadership and the possibilities of cartels and geopolitical problems are 
TABLE 3. (continued)

Factor

Production growth rate necessary to meet forecasted world consumption and solar requirements.

The largest single year market share consumed by solar over the period of the development plan.

The contributions to capital costs per unit of peak power.
Value Selected

$10 \%$

$10 \%$

$\$ 50 /$ KWe
Reason Selected

important when approximately $35 \%$ of current supply originates in a single non-U.S. supplier.

A sustained compound growth rate of $10 \%$ per year is unusual for most bulk material production processes and frequently puts severe pressures on capital, labor, and the environment.

When a single consumer of a material represents $10 \%$ of the world consumption, the possibility exists to significantly influence market prices.

Current capital costs for thermal power stations are reported to be about $\$ 1000 / \mathrm{KWe}$. We have estimated that if bulk material costs, using 1976 prices, are more than $5 \%$ of current capital costs or $\$ 50 / K W e$, the economic feasibility of the material's use is in question.

A comparable set of threshold criteria have been developed for identifying potential raw materials problems. For each factor previously discussed the chosen value and the rational for selecting those values are shown in Table 4.

\section{TABLE 4. Raw Material Threshold Criteria}

\section{Factor}

Percent of current consumption that is imported.
Value Selected

$50 \%$
Reason Selected

When a large percentage of the material originates outside of the U.S., the uncertainty surrounding future materials prices and availability is increased. Fifty percent of current materials 
TABLE 4. (continued)

Factor

Percent of world consumption supplied by the largest supplier country outside of the U.S.

Production growth rate necessary to meet forecasted world consumption and solar requirements.

Largest single year market share consumed by solar over the period of the solar development plan.

Percent of the world reserves that will be consumed by the year 2000 .

Percent of the U.S. reserves that will be consumed by the year 2000 .
$400 \%$

Value Selected

$60 \%$

$7 \%$

$10 \%$

$300 \%$
Reason Selected

consumption resulting from imports may not represent a problem if all imports do not originate in a few countries. However, the $50 \%$ level was selected as a general level of concern.

Raw materials suppliers tend to be larger \&, therefore, control a larger percentage of the market than bulk material suppliers. When a single supplier controls $60 \%$ of world consumption, raw materials availability is a potential problem.

The time required to develop raw material supplies is from $5-20$ years and a $7 \%$ compound growth rate appears to be an appropriate level of concern.

When a single consumer of a material represents $10 \%$ of world consumption, the possibility exists to significantly influence market prices.

A frequently used rule of thumb for appropriate reserve margins is 10 years at current consumption. With respect to using world reserves, we anticipate possible problems if we wish to consume 3 times known reserves over the next 20 years. This represents planned consumption of $300 \%$ of known world reserves.

Because U.S. reserves are much more certain, extensive use of reserves, up to 4 times the currently known reserves, may not be a problem. 
TABLE 4. (continued)

\section{Factor}

Percent of world resources that will be consumed by the year 2000
Value Selected $200 \%$

$300 \%$

Percent of U.S. resources

the year 2000

The contribution to capital costs of raw materials per unit of peak power
Reason Selected

The definition of reosurces includes presently uneconomic deposits and, therefore, consumption of a larger percentage may be a problem. A reasonable estimate appears to be in the range of $200 \%$. Thus, if we plan on consumption of 2 times currently known resources we anticipate raw material availability problems.

U.S. resources have less uncertainty than do world resources. We estimate that up to 3 times currently known deposits can be consumed by 2000 .

$\$ 50 / \mathrm{KWe} \quad$ Bulk materials costs of $\$ 50 / \mathrm{KWe}$ are likely to be a direct problem \&, therefore, a direct cost contribution of $\$ 50 /$ KWe from a raw material will certainly be a problem. Arguments to lower this value appear to have validity, but the actual amount of the reduction in this limit that is reasonable is not known.

These threshold values are meant as general guidelines and should not be taken as absolute decision criteria. Sensitivity analysis will reveal those materials that are close to exceeding one or more threshold levels and the parametric nature of the current threshold values allows for rapidly changing these criteria and observing the effect in terms of potential materials problems identified.

The next section of this report discusses an interactive computer system developed to provide rapid feedback to decision makers concerning the effects of various assumptions.

Interactive Computer System for Screening - An interactive computer system was designed to provide for rapid screening of bulk and raw materials and to allow for easily changin the materials requirements as solar designs are 
developing. This computer system also provides a capability to test the sensitivity of materials problems to assumed plans for commercialization and also to provide a dynamic environment in which the effects of alternative threshold levels can be explored. A functional diagram of the interactive computer system is shown in Figure 7.

The user-supplied input includes the selection of a specific solar design which can be changed to represent a new or improved solar system. A projected solar development plan and the threshold levels are also specified by the user.

The user-supplied inputs are merged with a solar materials data base to provide an assessment of the materials used on each of the screening factors. The major components of this data base include the following.

- Solar design data, including engineering and bulk material requirements for specific solar systems (see Appendices $A$ and $E$ for solar systems which have been characterized to date).

- A bulk materials data base with information on bulk materials usage (see Appendix B).

- A raw materials data base with information on raw materials usage (see Appendix C).

- A conversion matrix resulting from process analysis that provides factors for bulk to raw materials conversion (see Appendix D).

This materials data is combined with a solar development plan to determine materials requirements over time and to evaluate each material on each factor. Potential material problems are identified by application of the user-supplied threshold criteria levels. It is important to examine different levels of threshold values; since actual performance values for each materials on each factor is reported, the senstivity of a particular threshold value is apparent.

These results provide users with a rapid screening of potential bulk and raw material problems and an identification of the material requirements necessary in order to support the solar development plan. Based on this output, a detailed assessment of potential problem materials is initiated to determine the severity of each potential problem identified and to develop strategies 


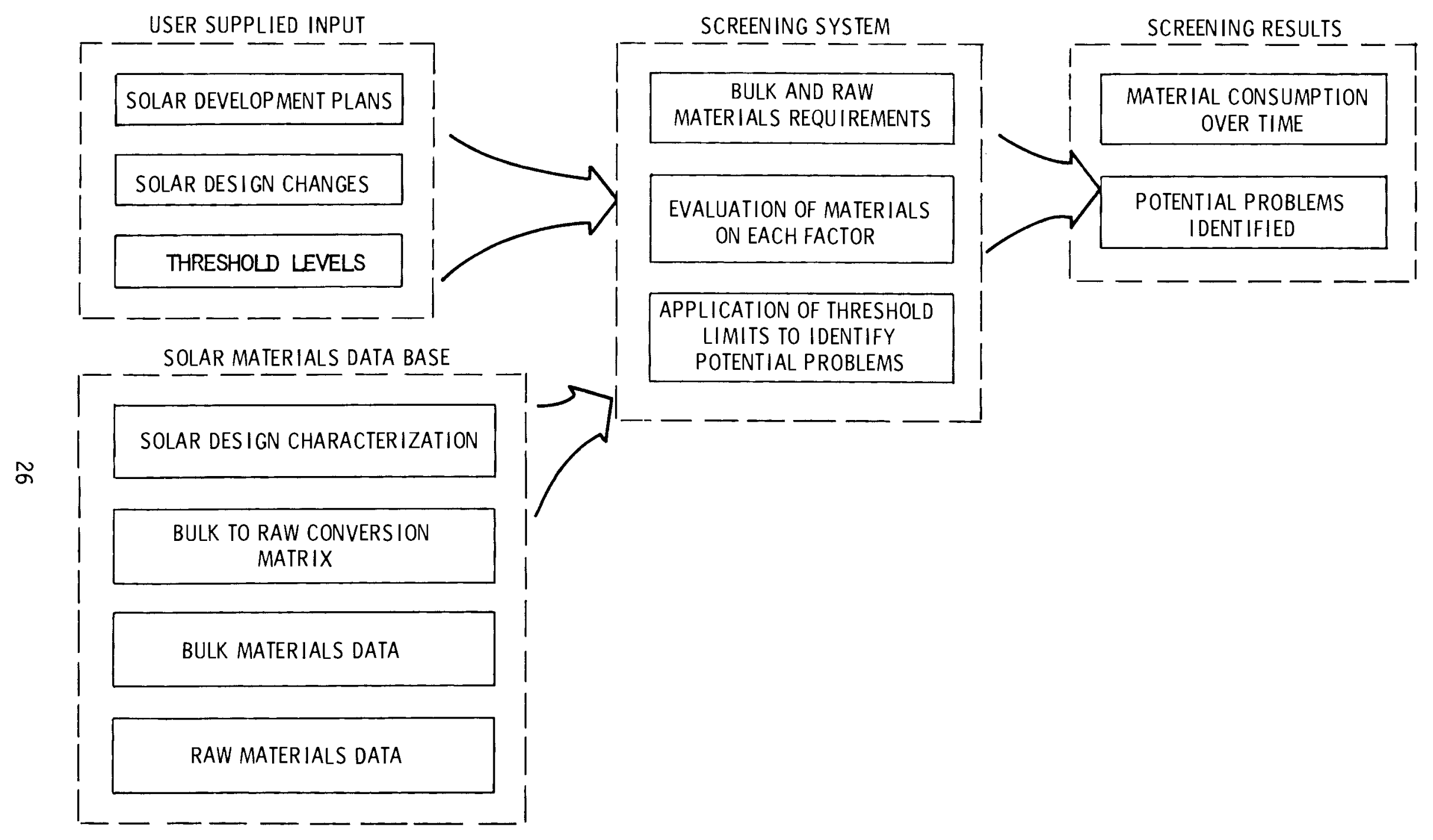

FIGURE 7. Interactive Screening System 
for mitigating potential material problems in the implementation of solar technology.

\section{ASSESSMENT OF POTENTIAL MATERIALS PROBLEMS}

Many possible materials problems are identified as a result of screening. Some of the important problems are as follows.

- Process and production contraints

- Reserve and resource limitations

- Lack of alternative supply sources

- Geopolitical problems

- Environmental and energy concerns

- Time constraints

- Economic constraints

Each of the above problem areas can have a significant impact on the technical and economic feasibility of a solar design. Some of these problem areas are specific to bulk or raw materials while others can afflict both forms of materials.

An assessment of bulk materials problems includes an analys is of current U.S. and world production capacity, future cost trends, level of imports and stockpiles, and the potential that exists for substitution and recycle. In assessing raw materials problems it is necessary to analyze geologic availability in addition to the areas of concern analyzed for bulk materials. For this reason, problem assessment is divided into two categories: (1) those problems relating to bulk materials and (2) those relating to raw materials.

The factors used to identify potential materials problems are shown in Figure 8.as a series of questions involving the level of each factor when compared to the threshold criteria. A potential problem is identified if any of these questions is answered in the affirmative. The assessment of each of the potential problems involves a review of each of the concerns listed in the boxes under each question. 


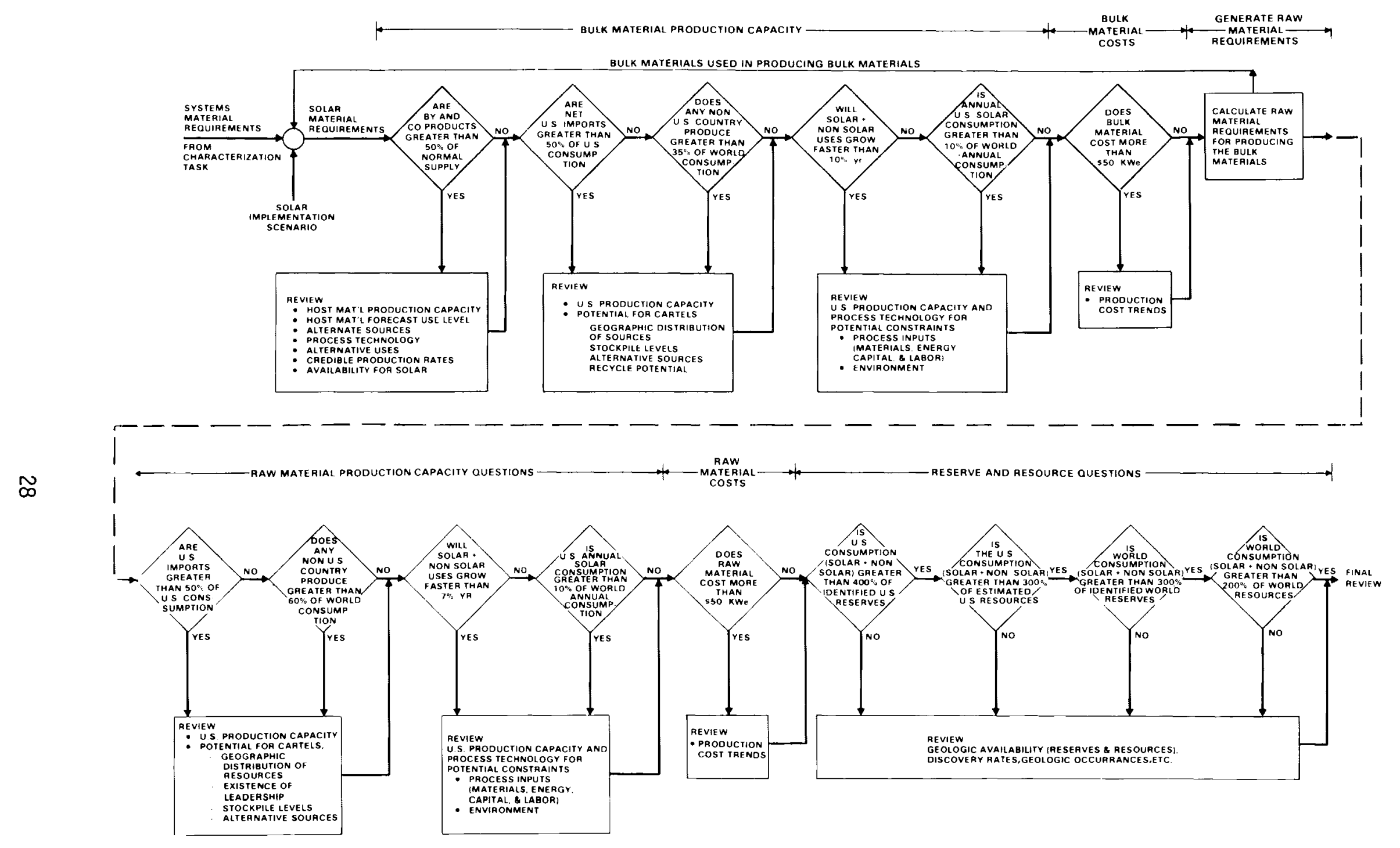

FIGURE 8. Assessment of Potential Materials Problems 


\section{EXAMPLE ANALYSIS OF POTENTIAL MATERIALS PROBLEMS}

The assessment methodology is demonstrated in this section for a photovoltaic system. Two alternative photovoltaic cells will be used in the system built by the Massachusetts Institute of Technology-Lincoln Laboratory. This system (see Figure 9) produces power to pump irrigation water to 80 acres of corn and soybeans at the University of Nebraska Field Laboratory near Mead. The unit's peak power output of $25 \mathrm{KW}$ makes it the largest photovoltaic power system in existence today.

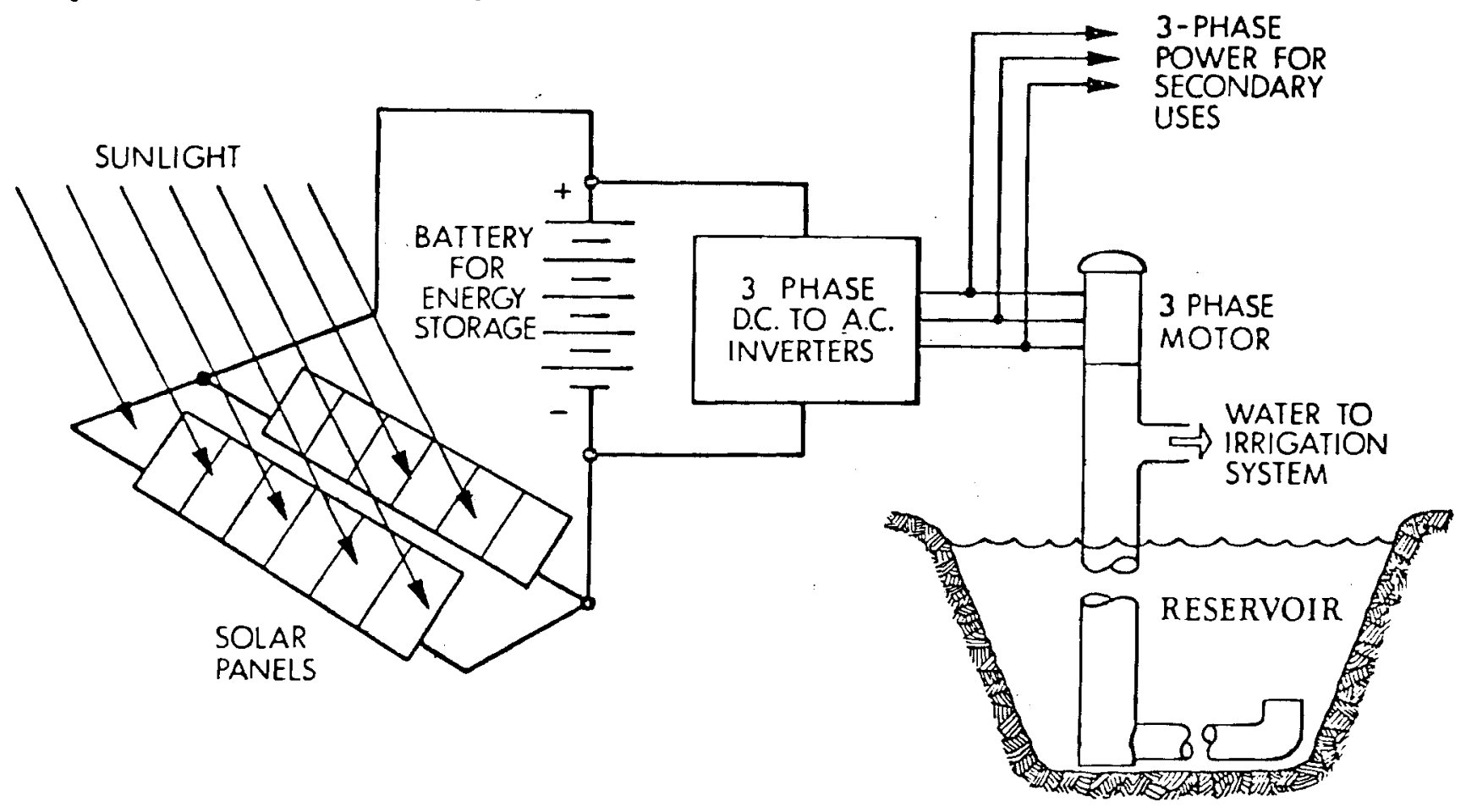

FIGURE 9. Massachusetts Institute of Technology-Lincoln Laboratory and University of Nebraska at Lincoln Photovoltaic System at Mead, Nebraska (SOURCE: MIT-Lincoln Laboratory)

Photovoltaie System Design - A total of 28 flat panels, each 8 feet by 25 feet, comprise the solar cell array. The array output (6.2 amps at 150 volts per panel) is fed to two buildings. One houses the system control equipment and inverters to convert the direct current (DC) produced by the solar cells into alternating current (AC) at 220 volts to power the irrigation pump motor and other loads. The other building houses 38 large lead-acid storage batteries capable of storing $85 \mathrm{KW}-\mathrm{hrs}$ 。 
The system is a prototype of future photovoltaic systems with two exceptions. The solar panel supports were designed to be tilted and may be more massive than the fixed supports envisioned in future systems. Also the technology of photovoltaic cells is advancing towards cells which are thinner and more efficient.

The materials requirements for 13 alternative photovoltaic cell designs have been assessed (see Appendix A). Two of these cell designs are being used in this report as an example assessment of the materials requirements and potential problems for a photovoltaic system.

One example uses silicon $\mathrm{n} / \mathrm{p}$ single crystal cells thinner than those currently in production. The cell efficiency assumed is $10.4 \%$, which is identical to the cells actually installed in the system at Mead, Nebraska. The engineering and bulk materials required to build $25 \mathrm{KW}$ of peak power output are shown in Table 5.

Photovoltaic Development Plans - For this example, the solar development plan begins in 1985 and increases at an exponential rate achieving an installed on-line capacity of 50 GWe by 2000 .

Achieving this goal of 50 GWe by 2000 for photovoltaics will probably require the development and commercialization of several photovoltaic designs. For the purposes of this example we have assumed that either of the cell designs may achieve the goal. In the future, it will be necessary to examine more complex solar development plans involving several designs. The current assessment methodology can accommodate solar development plans involving several solar technologies and designs.

\section{MATERIAL SCREENING AND PROBLEM IDENTIFICATION}

Bulk Material Screening - The two example designs, silicon n/p single crystal and the GaAs-MIS, will be screened to first identify those bulk materials that represent potnetial problems and then to identify those raw materials that may hinder the development of these designs. 
TABLE 5. Summary of Materials Contained in the MIT-LL. and UNL Photovoltaic System at Mead, Nebraska

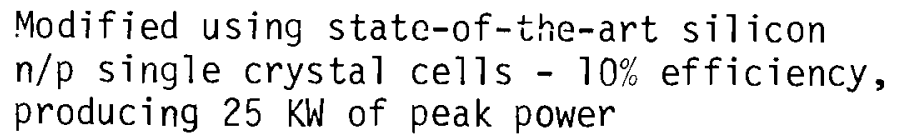

\begin{tabular}{|c|c|c|c|}
\hline $\begin{array}{l}\text { Enyincering } \\
\text { "Alloy" as llscd } \\
\text { in This Systeme. }\end{array}$ & $\begin{array}{l}\text { Quantity } \\
\text { Metric Yors }\end{array}$ & $\begin{array}{l}\text { Bult Materisi Cons:ituents } \\
\text { of Enyincering "Ailoy" }\end{array}$ & $\begin{array}{l}\text { Quantity } \\
\text { Metric Ions } \\
\end{array}$ \\
\hline Concrete & 101. & $\begin{array}{l}\text { Cectucil } \\
\text { Sand and Gravel } \\
\text { Stone }\end{array}$ & $\begin{array}{l}14.1 \\
29.3 \\
57.6\end{array}$ \\
\hline Carbon Steel & 5.89 & $\begin{array}{l}\text { Iron } \\
\text { Munganese }\end{array}$ & $\begin{array}{l}5.65 \\
0.04\end{array}$ \\
\hline Silicon Steel & 0.417 & $\begin{array}{l}\text { Iron } \\
\text { Silicon }\end{array}$ & $\begin{array}{l}0.404 \\
0.013\end{array}$ \\
\hline 6061 A) uminum & 13.9 & $\begin{array}{l}\text { Aluminum } \\
\text { Magresium } \\
\text { Silicon } \\
\text { Ferrochrone } \\
\text { Copes: }\end{array}$ & $\begin{array}{l}13.6 \\
0.139 \\
0.033 \\
0.049 \\
0.035\end{array}$ \\
\hline Polyvinyl Chloride & 0.024 & Polyvinyl Chloride & 0.024 \\
\hline Alurisinumi & 2.23 & Aluminum & 2.23 \\
\hline Copper & 1.07 & COpfer & 1.07 \\
\hline Plywood & 0.503 & $\begin{array}{l}\text { Sof twood } \\
\text { Adhesive-Pheriol fermald. }\end{array}$ & $\begin{array}{l}0.493 \\
0.010\end{array}$ \\
\hline Lead-0.3 Calciura & 1.44 & $\begin{array}{l}\text { Lead } \\
\text { Calciual }\end{array}$ & $4.32 \times 10^{1.44}$ \\
\hline Lead-5: Antiniony & 1.20 & $\begin{array}{l}\text { lead } \\
\text { Antionny }\end{array}$ & $\begin{array}{l}1.14 \\
0.06\end{array}$ \\
\hline Sulfuric Acid & 0.726 & Sulfuric Acid & 0.726 \\
\hline silicone & 1.86 & silicone & 1.86 \\
\hline Silicon & $2.91 \times 10^{-2}$ & silicon & $2.91 \times 10^{-2}$ \\
\hline Phosphorous & $2.59 \times 10^{-7}$ & Phosphorous & $2.59 \times 10^{-7}$ \\
\hline Boron & $2.26 \times 10^{-9}$ & Boren & $2.26 \times 10^{-9}$ \\
\hline Titaniun & $2.26 \times 10^{-6}$ & Titaniun & $2.26 \times 10^{-6}$ \\
\hline Palladiunit & $2.93 \times 10^{-6}$ & Palladiun & $2.93 \times 10^{-6}$ \\
\hline Silver & $6.55 \times 10^{-4}$ & silver & $6.55 \times 10^{-4}$ \\
\hline Tantalum & $1.68 \times 10^{-4}$ & Tor:talum & $1.68 \times 10^{-4}$ \\
\hline Teflon & $3.26 \times 10^{-3}$ & Iefion & $3.26 \times 10^{-3}$ \\
\hline Stainiess Stecl & 1.24 & $\begin{array}{l}\text { Iror. } \\
\text { Ferrochrome } \\
\text { kickel }\end{array}$ & $\begin{array}{l}0.878 \\
0.322 \\
0.057\end{array}$ \\
\hline $\begin{array}{l}\text { Plastics and } \\
\text { loninates }\end{array}$ & $9.76 \times 10^{-3}$ & Plastics and Larifrates & $9.76 \times 10^{-3}$ \\
\hline Rubber & $2.49 \times 10^{-2}$ & RutEer & $2.49 \times 10^{-2}$ \\
\hline $60-40$ Solder & $2.36 \times 10^{-2}$ & $\operatorname{lin}_{\text {Lead }}$ & $\begin{array}{l}1.49 \times 10^{-2} \\
0.87 \times 10^{-2}\end{array}$ \\
\hline FRP Polyes:er & 1.08 & $\begin{array}{l}\text { Polyester } \\
\text { Fiberglass }\end{array}$ & $\begin{array}{l}0.57 \\
0.57\end{array}$ \\
\hline Soda Lime Glass & $0.68 \times 10^{-3}$ & Sod: Line Glass & $0.68 \times 10^{-3}$ \\
\hline Fiberglass 1001 & 0.898 & Fiberglass & 0.838 \\
\hline Acrylic & 0.053 & Acrylic & 0.053 \\
\hline Pheriolic & 0.015 & Phenolic & 0.015 \\
\hline Epoxy & $9.07 \times 10^{-4}$ & Epoxy & $9.07 \times 10^{-4}$ \\
\hline Polypropylene & 0.207 & Polypropylene & 0.207 \\
\hline Varnish & $6.80 \times 10^{-3}$ & $\begin{array}{l}\text { Alkjd Resin } \\
\text { Tunj oil } \\
\text { Linseed oil }\end{array}$ & $\begin{array}{c}6.80 \times 10^{-3} \\
10.2 \times 10^{-3} \\
3.4 \times 10^{-3}\end{array}$ \\
\hline Zinc & $0.68 \times 10^{-3}$ & Ziris & $0.68 \times 10^{-3}$ \\
\hline $\begin{array}{l}\text { Electrical } \\
\text { Porcelain }\end{array}$ & $0.34 \times 10^{-3}$ & Porcelain & $0.34 \times 10^{-3}$ \\
\hline $\begin{array}{c}\text { Epoxy/Glass } \\
\text { Laminate }\end{array}$ & $0.24 \times 10^{-3}$ & $\begin{array}{l}\text { Epoxy } \\
\text { Fiberglass }\end{array}$ & $\begin{array}{l}0.084 \times 10^{-3} \\
0.156 \times 10^{-3}\end{array}$ \\
\hline Hylon & $0.5 \times 10^{-3}$ & Nylon & $0.5 \times 10^{-3}$ \\
\hline Micarta & $9.16 \times 10^{-4}$ & $\begin{array}{l}\text { Phenolic } \\
\text { Cotion Fibers } \\
\text { Kreft Fibers }\end{array}$ & $\begin{array}{l}4.58 \times 10^{-4} \\
3.21 \times 10^{-4} \\
1.37 \times 10^{-4}\end{array}$ \\
\hline Polyester & $4.08 \times 10^{-3}$ & Polyester & $4.08 \times 10^{-3}$ \\
\hline
\end{tabular}


By applying the same development plan to both of these photovoltaic systems, one can identify those materials that represent significant problems if the DOE goal of 50 GWe in the year 2000 is achieved by commercialization of either silicon $\mathrm{n} / \mathrm{p}$ single crystal or the GaAs-MIS. While this is an unrealistic scenario for achieving the photovoltaic goal, it is useful for demonstrating the power of this methodology as a tool to provide early warning of materials problems and to impact on future solar R\&D programs.

Sample output from the computer system analysis is shown in Table 6 for the silicon $n / p$ single crystal example. Bulk material requirements and an evaluation of each bulk material on each of the important factors relative to bulk materials usage is also shown. The specified threshold levels at the top of each column are used to identify potential material problems. Used as decision criteria the threshold values identify problems with an asterisk (*).

The GaAs-MIS example results are shown in Table 7. Many of the materials that represent potential problems to the silicon $n / p$ cells are identified as potential problems in the GaAs-MIS design.

By inspection of each of the materials on which potential problems have been identified (Tables 6 and 7), we have made a preliminary grouping of materials into three categories. The first category contains those materials whose technical availability or economic feasibility appear to have significant impact on commercial implementation of the solar designs. The second category contains those materials on which potential problems have been identified; however, as a result of a brief review, these problems do not appear to be of sufficient severity to impact significantly on the implementation of solar designs. The final group contains those materials on which no apparent problems have been identified.

The results of grouping these materials problems are shown in Table 8. Each of the materials in Group "A" represent potential problems of sufficient severity that additional, more detailed assessment is necessary in order to determine the significance of the problems identified and to recommend strategies for mitigating these problems. Stainless steel has 
TABLE 6. Bulk Material Requirements for Silicon N/P Single Crystal SOLFR SEENARIO

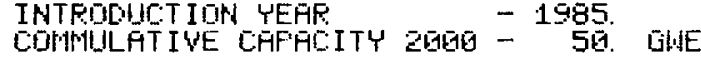

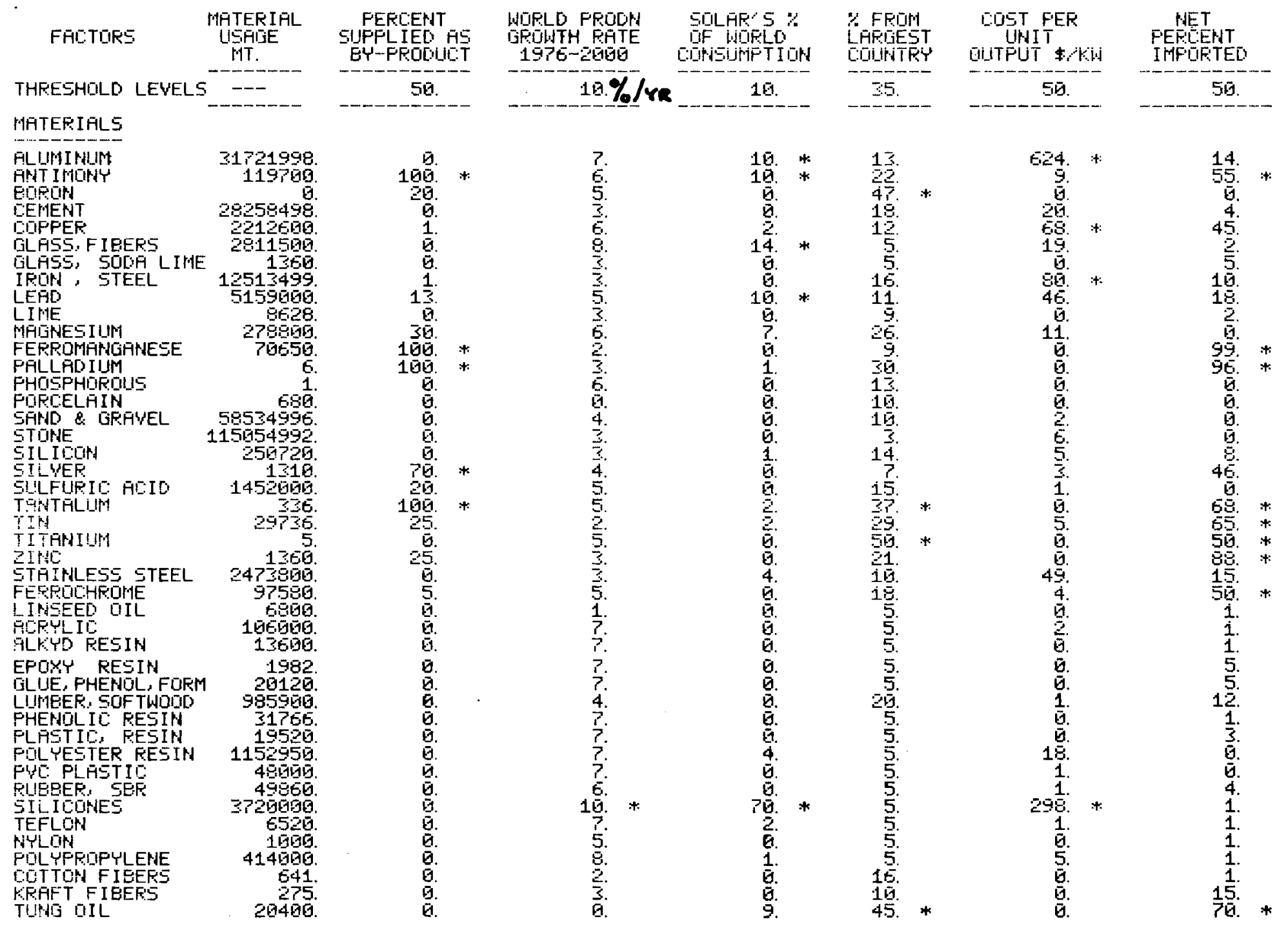


TABLE 7. Bulk Material Requirements for GaAs-MIS Thin Film Cell

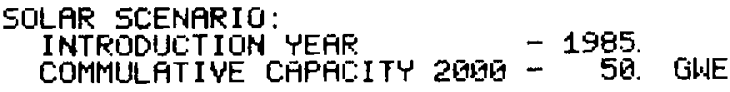

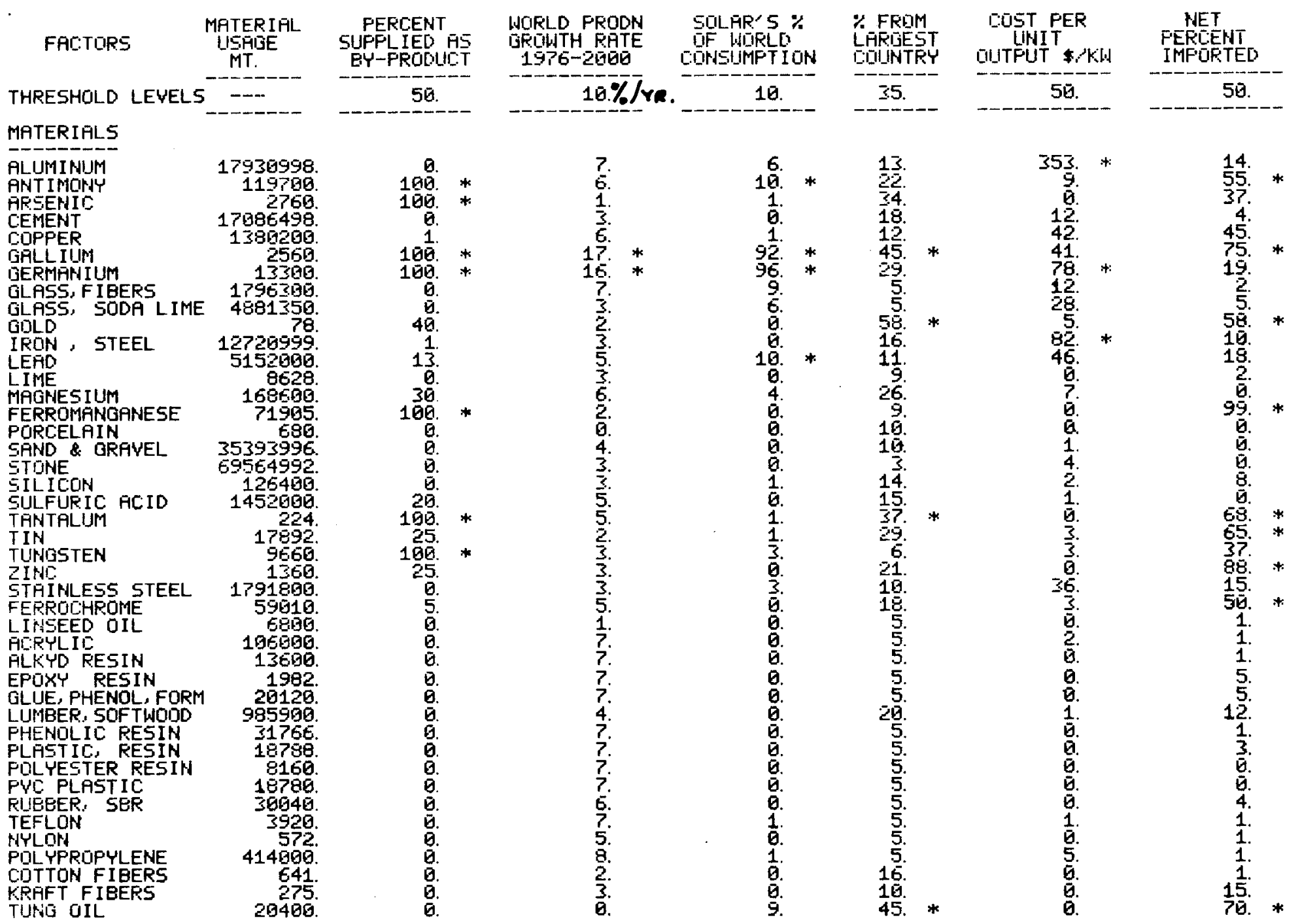


TABLE 8. Potential Bulk Materials Problems

\begin{tabular}{|c|c|c|}
\hline $\begin{array}{c}\text { Group "A" } \\
\text { Potentially } \\
\text { Severe Problems } \\
\end{array}$ & $\begin{array}{l}\text { Group "B" } \\
\text { Problems } \\
\text { Identified }\end{array}$ & $\begin{array}{l}\text { Group "C" } \\
\text { No Problems } \\
\text { Identified }\end{array}$ \\
\hline $\begin{array}{l}\text { Aluminum } \\
\text { Antimony } \\
\text { Copper } \\
\text { Gallium } \\
\text { Germanium } \\
\text { Iron \& Steel } \\
\text { Silicones }\end{array}$ & $\begin{array}{l}\text { Arsenic } \\
\text { Boron } \\
\text { Ferrochrome } \\
\text { Ferromanganese } \\
\text { Gold } \\
\text { Glassfiber } \\
\text { Lead } \\
\text { Palladium } \\
\text { Silver } \\
\text { Tantalum } \\
\text { Tin } \\
\text { Titanium } \\
\text { Tungsten } \\
\text { Tung Oi1 } \\
\text { *Stainless Steel }\end{array}$ & $\begin{array}{l}\text { Those materials } \\
\text { listed in Tables } \\
6 \text { and } 7 \text { not listed } \\
\text { in Group "A" or " } B \text { " } \\
\text { at the left }\end{array}$ \\
\hline
\end{tabular}

been included as a Group "B" material because it nearly exceeds the threshold criteria on several important factors although it does not exceed the threshold on any screening factor.

Row Materials Screening - For all bulk materials used in the construction of silicon $n / p$ and GaAs-MIS systems the raw materials needed to produce these bulk materials are determined from process analysis. Sample output from screening these raw materials is shown in Tables 9 and 10, along with the estimated materials usage to construct 50 GWe of either design.

Table 9 presents the results of screening raw materials used in the silicon $\mathrm{n} / \mathrm{p}$ single crystal system. Significant quantities of raw materials are required to construct 50 GWe of this system. Antimony ore and bauxite are possibly significant problems from a reserves and resources perspective. A rather large quantity of salt $(120 \mathrm{million}$ MT) is required to produce the required aluminum. This could represent an important contribution to the installed cost of constructing the design. 
TABLE 9. Raw Material Requirements for Silicon N/P Single Crystal

SOLAR SCENARIO

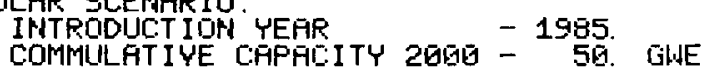

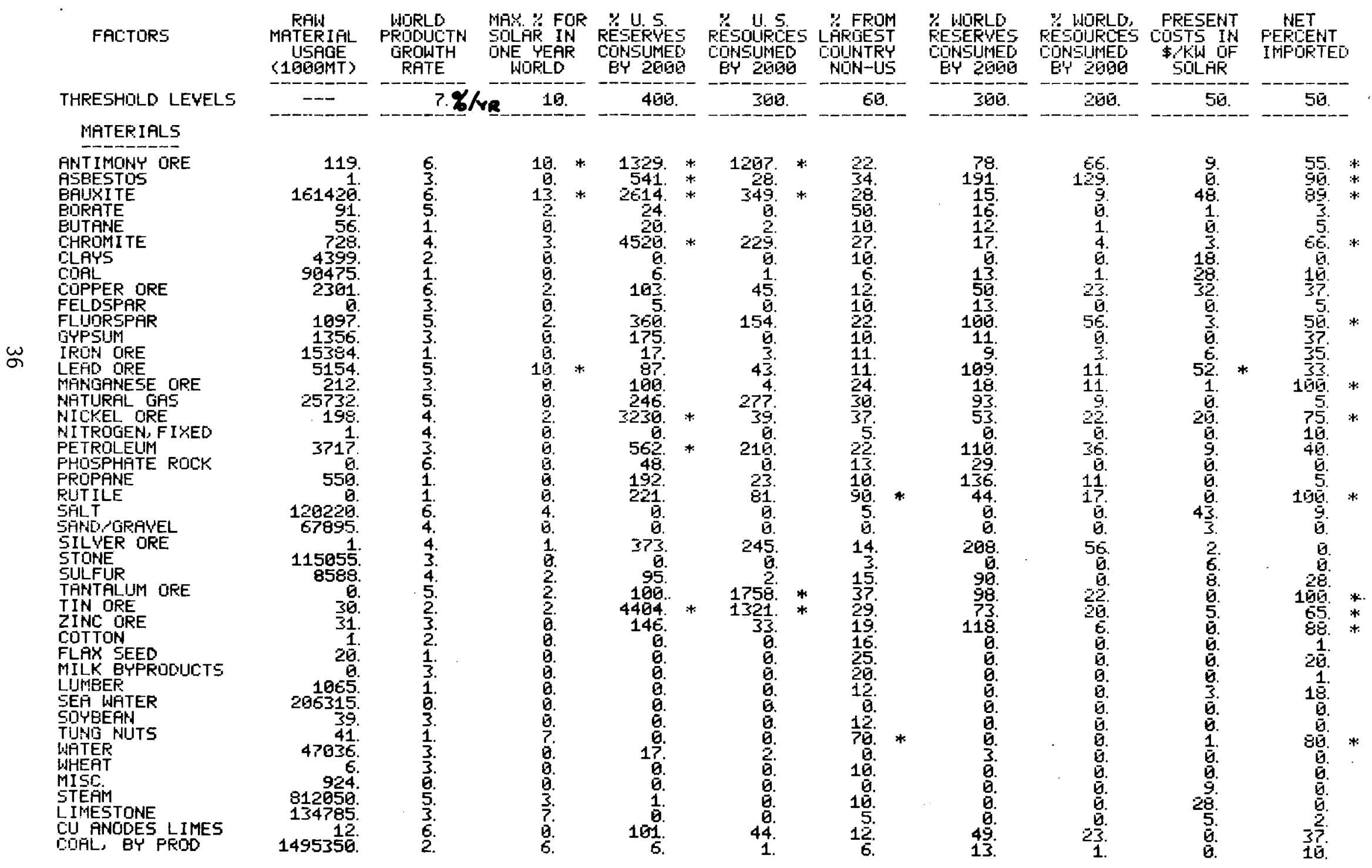


TABLE 10. Raw Material Requirements for GaAs-MIS Thin Film Cell

SOLFR SCENARIÓ:

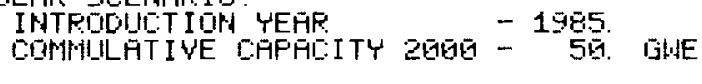

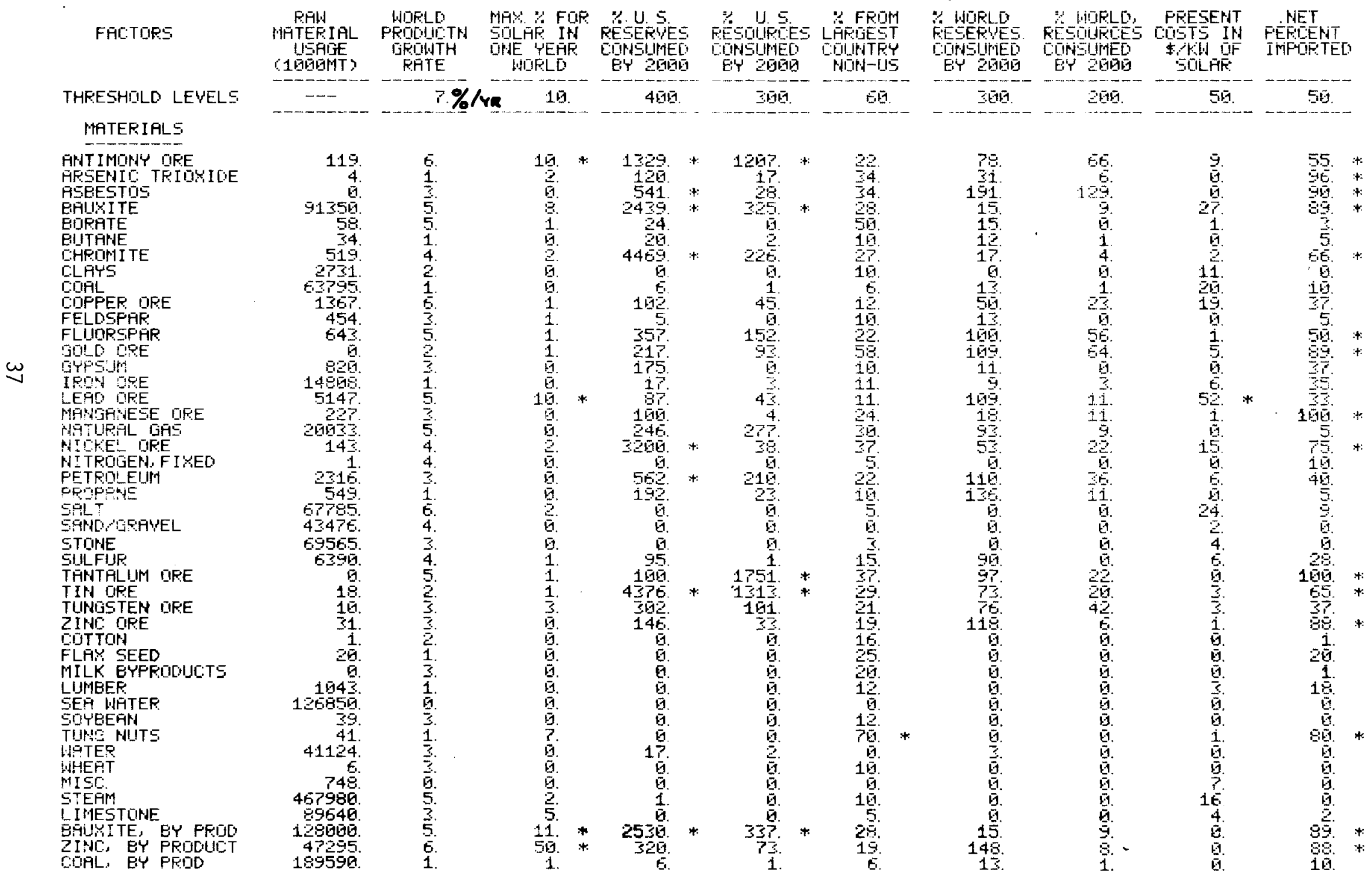


The raw material requirements to construct 50 GWe of the GaAs-MIS system are shown in Table 10. Most of these requirements are lower than those for the silicon system; however, bauxite and zinc byproducts represent bauxite and zinc ore production required to produce gallium and germanium and may represent problems in the development of this system if they exceed bauxite requirements for the primary material, aluminum.

A summary of potential raw materials problems identified in Tables 9 and 10 is shown in Table 11. Each of the materials in Group "A" represent potentially severe problems and will be discussed in more detail in the following section.

TABLE 11. Raw Material Screening Results for the Two Photovoltaic Designs

\begin{tabular}{|c|c|c|}
\hline $\begin{array}{c}\text { Group "A" } \\
\text { Potentially } \\
\text { Severe Problems } \\
\end{array}$ & $\begin{array}{l}\text { Group "B" } \\
\text { Problems } \\
\text { Identified }\end{array}$ & $\begin{array}{l}\text { Group "C" } \\
\text { No Problems } \\
\text { Identified } \\
\end{array}$ \\
\hline $\begin{array}{l}\text { Antimony Ore } \\
\text { Bauxite } \\
\text { Bauxite Byproduct } \\
\text { (Gallium Source) } \\
\text { Zinc Ore Byproduct } \\
\text { (Germani }\end{array}$ & $\begin{array}{l}\text { Arsenic Trioxide } \\
\text { Asbestos } \\
\text { Chromite } \\
\text { Fluorspar } \\
\text { Gold Ore } \\
\text { Lead Ore } \\
\text { Manganese Ore } \\
\text { Natural Gas } \\
\text { Nickel } \\
\text { Petroleum } \\
\text { Rutile } \\
\text { Tantalum Ore } \\
\text { Tin Ore } \\
\text { Tung Nuts } \\
\text { Zinc Ore }\end{array}$ & $\begin{array}{l}\text { Those materials listed } \\
\text { in Tables } 9 \text { and } 10 \text { not } \\
\text { listed in Group "A" or } \\
\text { "B" to the left. }\end{array}$ \\
\hline
\end{tabular}

\section{ASSESSMENT OF MATERIALS PROBLEMS}

The screening process rapidly identifies potential bulk and raw materials problems that may hinder the implementation of the example photovoltaic designs. Once materials problems are identified, a more detailed 
materials assessment provides an analysis of the most serious concerns anci establishes alternative strategies available for mitigating or managing these materials problems.

The following discussion provides a detailed assessment of each bulk and raw material placed in Group "A" in Tables 8 and 11.

Aluminum Bulk Material Concems - The screening process (Tables 6 and 7) identified two potential problems with aluminum bulk materials necessary to produce 50 GWe of peak power capacity using either of the reference solar cell designs. The first problem is associated with the high consumption of aluminum in the reference designs. The second and related problem is the high cost of aluminum per kilowatt of peak capacity. There are two possibilities for mitigating there problems. They are as follows.

- Redesign these photovoltaic systems to minimize the use of aluminum.

- Find new and innovative ways to reduce the real cost of aluminum.

Reducing the usage of aluminum in these solar systems offers the best possibility for eliminating the aluminum bulk materials problems. The reference designs were intended principally as a technical demonstration and not as a commercial prototype. For this reason, it is highly likely that the aluminum content can be significantly reduced in future designs in one or more ways:

- using thinner or smaller structural members,

- developing higher efficiency cells requiring fewer support members,

- developing cells with better packing factors, requiring fewer support members, and

- substituting other materials for aluminum.

Through design improvements or material substitutions the aluminum requirements for commercial photovoltaic systems could be substantialiy 
reduced over these experimental designs. Therefore, potential problems with respect to high bulk aluminum consumption are likely to be eliminated.

The criteria for selecting aluminum in the reference designs are unknown at this time. However, much of the aluminum is used in supporting frames for the photovoltaic cells, and it appears that other structural materials could be readily substituted. For this reason, we recommend that additional development of these photovoltaic designs be directed toward the identification and development of less costly substitute materials for a luminum.

The more serious problem is the high cost of aluminum per kilowatt of capacity, $\$ 624 / \mathrm{KW}$ and $\$ 355 / \mathrm{KW}$ from Tables 6 and 7 . Even assuming greatly reduced usage in the commercial designs, the cost of aluminum components will probably be a significant fraction of the photovoltaic system cost.

The possibility of reducing the real cost of aluminum does not appear promising. Aluminum prices in constant dollars have shown significant cost reductions in the past (Figure 10). Figure 10 shows three projections of the probable future constant dollar costs of aluminum. The most likely projection is for a $50 \%$ price increase caused primarily by substantially higher energy and environmental control costs. The pessimistic estimate assumes a cartel scenario which restricts bauxite production forcing the substitution of higher cost domestic clays, thus adding further to the price pressures caused by energy and environmental control costs. The optimistic estimate assumes technology development will offset cost increases in energy and environmental control. However, because of the maturity of the aluminum industry, it would not be prudent to base a solar design strategy on expectations of major price reductions resulting from technology improvements in aluminum production.

Aluninum - Row Material Concerns - Bauxite - Tables 9 and 10 identify several potential problems relative to bauxite supply; the major concern relates to the lack of domestic sources of bauxite. Because of the reliance on imports for bauxite, the potential exists for cartels or foreign 


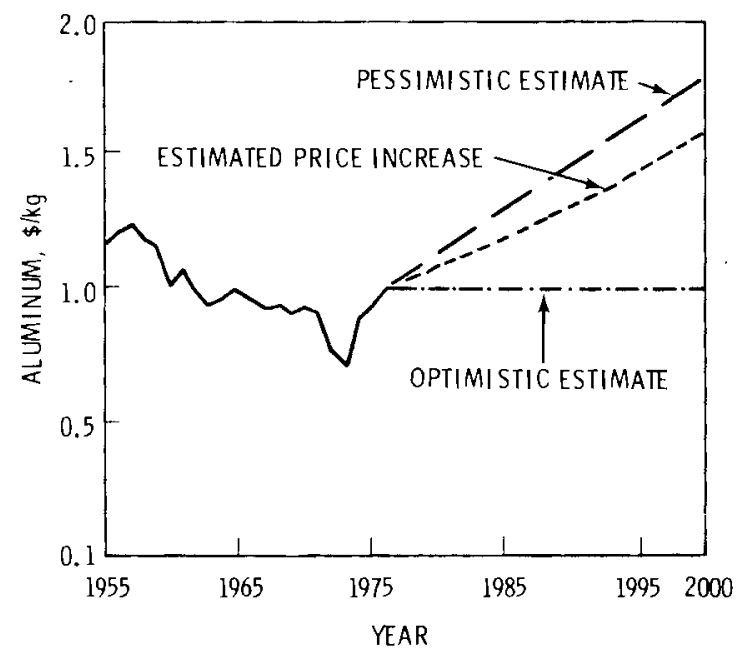

FIGURE 10. Price History and Future Price Estimates for Bulk Aluminum in 1976 Dollars

political actions to disrupt the normal supply of bauxite. A similar situation exists for foreign supplies of petroleum, thus bringing the OPEC cartel into existance. However, cartel formation appears unlikely for bauxite, as compared to petroleum, because: (1) bauxite deposits are plentiful and dispersed around the world, and (2) domestic clays can be used to produce aluminum at a modest increase in cost. Large domestic deposits of these clays have been identified. These two factors tend to discourage the formation of constraints for the world bauxite market.

The probable reduction in the usage of aluminum in commercial photovoltaic systems, resulting from improved designs and materials substitution, should eliminate the other concerns identified in Tables 9 and 10. Although the projected consumption of U.S. bauxite reserves is very high, back up resources, the domestic clays cited above, are plentiful; therefore, bauxite as a raw material should not be a significant problem.

Antimony - Bulk and Row Material Concerns - Although the screening process flags both bulk antimony and antimony ore as potential concerns, our detailed assessment concludes that antimony is not likely to be a significant problem to the development of photovoltaic systems. Antimony was flagged because it is almost completely obtained as a byproduct or co-product of 
lead production, and $55 \%$ is currently imported. However, it is unlikely that external action could effectively manipulate prices or control supply of antimony because: (1) antimony sources are dispersed (only $22 \%$ of current antimony production originates in the largest supplying country outside the U.S.), (2) the cost contribution of antimony in these designs is modest so that significant price variation could be tolerated, and (3) substitute materials for antimony in these designs are available and have proved satisfactory.

Copper - Bulk Material Concerns - The only potential problem identified for copper is its cost in the silicon cell (Table 6). In the silicon $\mathrm{n} / \mathrm{p}$ single crystal design the cost contribution of copper is $\$ 68 / \mathrm{KW}$ of capacity, the fourth highest cost material. This is $\$ 18 / \mathrm{KW}$ above the threshold level for cost concern. Three possible ways of reducing the cost contribution of copper in this design are:

1. Develop new and lower priced copper supplies.

2. Design for less copper use.

3. Substitute other materials for copper.

Copper price trends in constant dollars are shown in Figure 11 along with the decreasing copper ore grade over the 1 ast 25 years. Copper prices have historically increased about $2 \%$ per year while the ore grade utilized in copper production has steadily decreased at about $2 \%$ per year. Technological improvements in the production and mining processes for copper have reduced the direct man-hours per ton from about 25 to 17 in 1975 (see Figure 12). Without these technological improvements, it is likely that the price of copper would have risen at a rate greater than $2 \%$ per year. If the real price of copper continues to increase at about $2 \%$ per year, the constant dollar price for copper in the year 2000 will be about $50 \%$ higher than current copper prices. Copper prices are related to, and limited by, the price of functionally competitive materials. Aluminum is the primary competition, but, as we discussed previously, aluminum is likely to experience significant cost increases in the future. For this reason, competition is unlikely to constrain future price increases for copper. Declining ore grades, coupled with increased cost of 


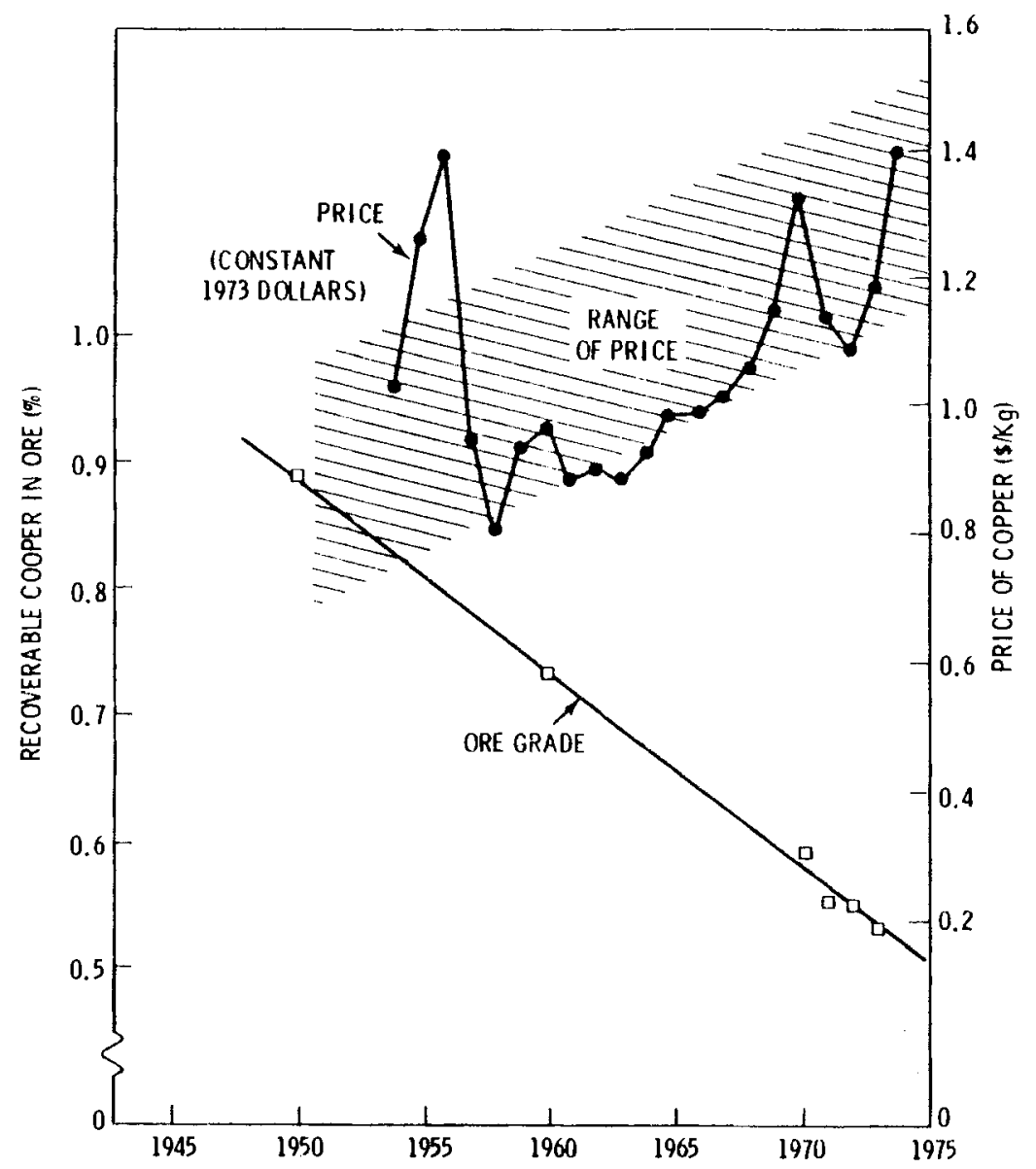

FIGURE 11. Copper Prices and Grade of Copper Ore

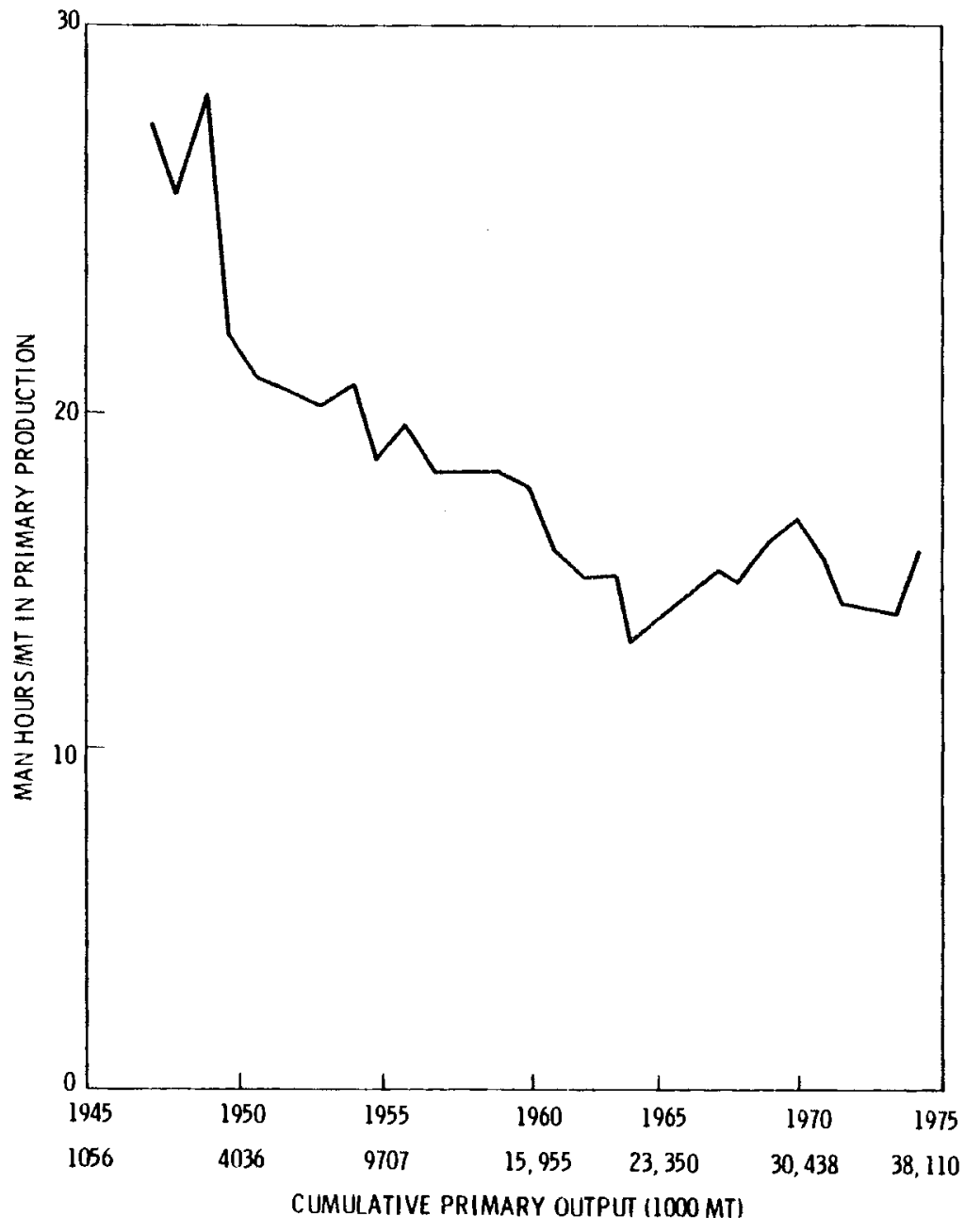

FIGURE 12. Productivity in the Copper Industry, 1947-1975

SOURCE: H.J. Schroeder, Copper Chapter in Mineral Facts and Problems, USBM Bulletin 667, pp. $293-310,197 \overline{6}$. 
energy and environmental controls (as with aluminum), are expected to cause upward pressure on production costs and prices.

Designs which use less copper are possible if: (1) higher efficiency photovoltaic cells or concentrating designs are developed, (2) better geometric packing factors for arranging these cells are developed, or (3) transformation and/or voltage step-up designs which enable the use of smaller wires are developed. Implementing these alternatives could considerably reduce the quantity of copper used in these solar photovoltaic designs.

Aluminum is the only practical substitute for copper in these designs. Since the cost of aluminum is expected to increase faster than copper, the substitution of aluminum for copper will probabiy not lead to a cost reduction. Therefore, of the three alternatives only designs using less copper offer the potential to reduce the costs attributable to copper.

Galizum - Bulk Matemal Concems - The screening process identified gallium in the Gallium Arsenide (GaAs) System as a potential problem material in meeting the goal of 50 GWe in the year 2000 (Table 7). Gallium is almost entirely derived as a byproduct. In order to meet the needs for gallium in the GaAs design, as well as other forecasted uses of gallium, a $17 \%$ compound growth rate in production is necessary. Photovoltaic uses alone would require $92 \%$ of the world gallium production. Of current world production, $45 \%$ is supplied by one foreign country and imports of gallium are $75 \%$ of the domestic requirements. Because these photovoltaic systems would consume nearly all of the gallium production and because of the potential for cartels or foreign political actions to restrict supplies, serious supply price and capacity disruptions could develop. Since gallium is essential to the reference design, there is concern both to the stability of the price and supply. Under current prices, gallium contributes $\$ 41 / \mathrm{KW}$ to the capital cost of the system (Table 7).

Gallium is presently recovered as a byproduct of zinc and aluminum production. A potential constraint arises if solar's needs exceed the amount available as a byproduct of producing these two materials. 
We have estimated that gallium for the development of the incremental peak capacity in the year 2000 requires approximately 28.4 million metric tons of bauxite. This represents about $11 \%$ of the forecasted bauxite production in the year 2000. Therefore, sufficient gallium should be available from expanded bauxite production alone to satisfy the needs of this photovoltaic system. Gallium, above the level available from aluminum and zinc production, would have to be acquired in one of two ways.

- A directly minable source would have to be located and developed, or

- Adequate supplies of mother ores must be processed annually to provide the needed byproduct gallium.

A directly minable source of gallium may be available from domestic clays. However, sufficient demand would have to exist to attract the necessary capital to develop these resources. Some clays contain about 50 grams of gallium per ton. Assuming $1 / 3$ recovery of the gallium, it would be necessary to process about 50,000 tons of clay to get one ton of gallium. Gallium prices are currently $\$ 800,000 /$ metric ton, and current U.S. annual consumption is about 8 metric tons. Since extracting gallium from clays is expected to be more costly than byproduct recovery, this would only be undertaken if foreign sources of byproduct gallium were restricted. However, because of our dependence on foreign supplies it may be necessary to initiate R\&D support directed toward lower cost gallium recovery from domestic clays if the GaAs system is pursued.

A major concern exists with respect to the cumulative production growth rate required for gallium. The annual U.S. consumption, at present, is in the range of 8 metric tons per year. A capacity of 50 GWe would require about 2,560 metric tons of gallium. Rapid expansion of gallium production is required by the development of this photovoltaic system, and significant materials management will be required in order to achieve a reasonably stable price.

Gallium production processes are extremely capital intensive. A stable long-term demand would be required to induce the needed capital investments. Early investments in R\&D, along with long-term guaranteed 
purchases, may be necessary in order to reduce the costs of gallium production and to provide incentives for capital investment to expand production capacity.

Considerable opportunity exists for process improvement since gallium is currently produced in a batch mode. In Figure 13, we can trace the price history of gallium. This depicts the development of an industry where prices have been dramatically reduced as production increased. The dashed lines on Figure 13 indicates considerable potential for further technology development. Developing continuous gallium production processes along with a scale-up on capacity, should reduce the capital costs and unit prices of gallium. This will not be achieved without additional R\&D support directed toward lower cost gallium byproduct recovery technology.

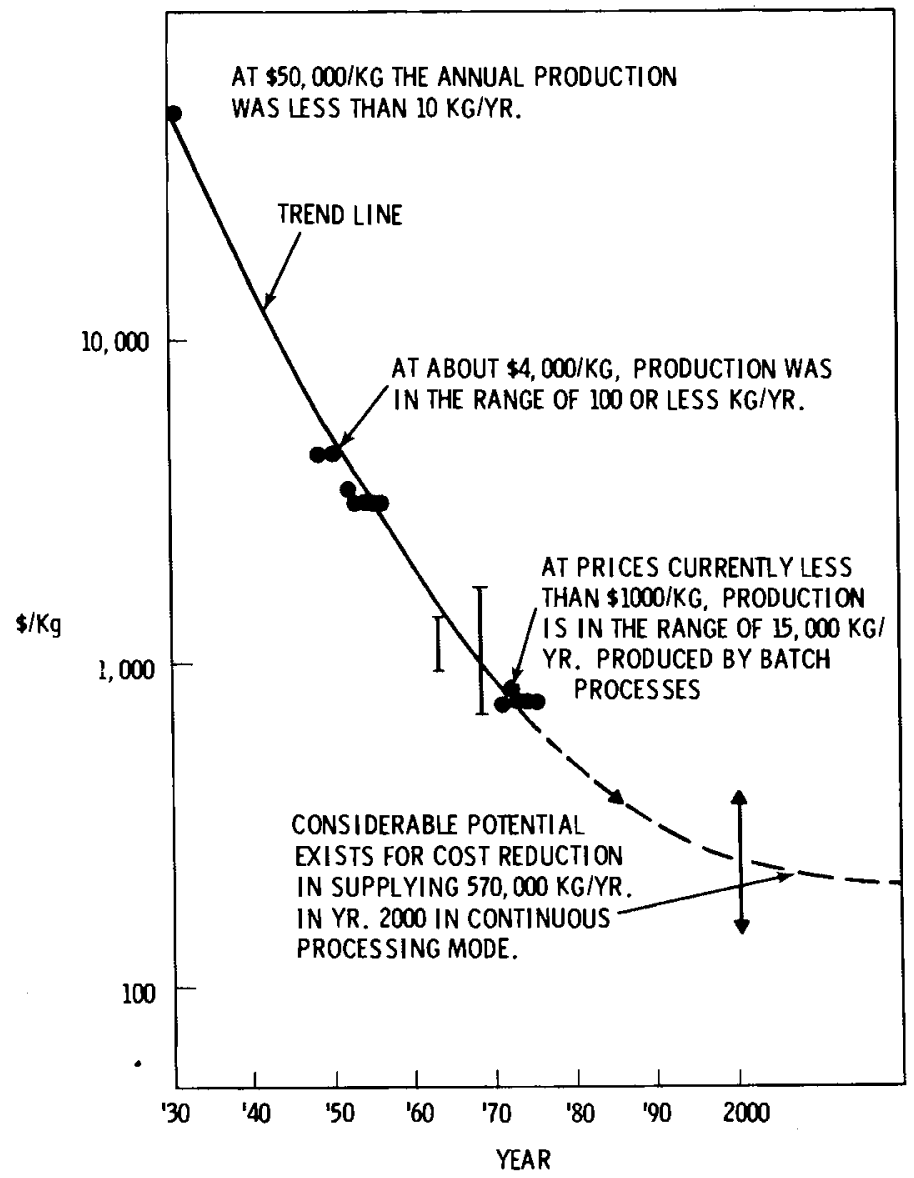

FIGURE 13. Price History for Gallium 
Future gallium prices appear to be particularly uncertain since most of the gallium consumed in the U.S. is imported and world supplies of gallium originate largely in one country. The potential for price manipulation is particularly significant with gallium. Most gallium is currently recovered during the process of converting bauxite to alumina. The current trend is for conversion to be accomplished at the bauxite mines overseas. Therefore, the future sources of gallium are likely to be under greater foreign control than at present. In addition, because of the large capital investment required for gallium recovery, it is likely that only the largest bauxite producers will install a gallium recovery process. Each of these factors will tend to concentrate gallium production among a few producers which in turn may adversely impact the future price stability and supply for gallium.

While sufficient gallium exists in aluminum production processes to meet the needs of the GaAs system, significant improvements are necessary in gallium recovery processes and large increases are necessary in gallium production capacity. In addition, price uncertainty exists with respect to foreign control of gallium recovery processes currently held by only a few large bauxite producers. Three strategies exist for mitigating future gallium problems if the GaAs system is seriously pursued.

- Support R\&D to develop improved gallium recovery processes

- Provide long-range incentives and guarantees to inspire the capital investment necessary to rapidly increase production capacity

- Develop improved cell designs that minimize gallium requirements

Germanium Buzk and Raw Matevial Concerns - Germanium, potentially a critical material in the GaAs photovoltaic system (see Table 7), generates the following concerns:

- $100 \%$ supplied as a byproduct of zinc production

- Compound growth rate of 16\%/year

- Almost total dominance of the market by solar (96\%)

- High cost contribution of $\$ 78 / \mathrm{KWe}$ 
Table 10 reveals that solar requirements for "zince byproduct" (sludges needed as raw materials in germanium production) are very large compared to expected future production rates.

Germanium is presently recovered primarily from the sludges of zinc smelting and refining. A potential constraint arises if solar needs exceed the economically available byproduct output. In this case, germanium needs would have to be met by:

1. finding a directly minable ore,

2. exploiting a new byproduct source, and/or

3. designing for the use of less germanium.

There is no known primary ore which has a potential for economic recovery of germanium; therefore, germanium will probably remain a byproduct of other processes. The most likely source for additional germanium is from coal combustion residues (ashes, clinkers, etc.).

Present prices for germanium are based on processing higher grade sludges from zinc recovery. We expect that meeting the goal for photovoltaics with the GaAs system would require processing lower grade sludges. Therefore, if faced with a significantly increased demand, future germanium prices are expected to increase. A price history and our projection of future cost trends for germanium is shown in Figure 14. Our most optimistic estimate is based on offsetting the higher costs of germanium recovery from lower grade byproducts by the "learning curve" effects associated with increased production quantities. Additional R\&D could produce a technology advance in germanium production but this cannot be assured.

At the present time research is already going on to find a replacement for the germanium layer in the GaAs-MIS device. This would appear to be the best approach to mitigating germanium problems. Thinner germanium layers would also help; however, the layer thickness assumed in the reference design is already thinner than cells being produced in the laboratory.

To help resolve potential germanium supply problems, we recommend: (1) a modest R\&D program to determine the feasibility of a lower cost 


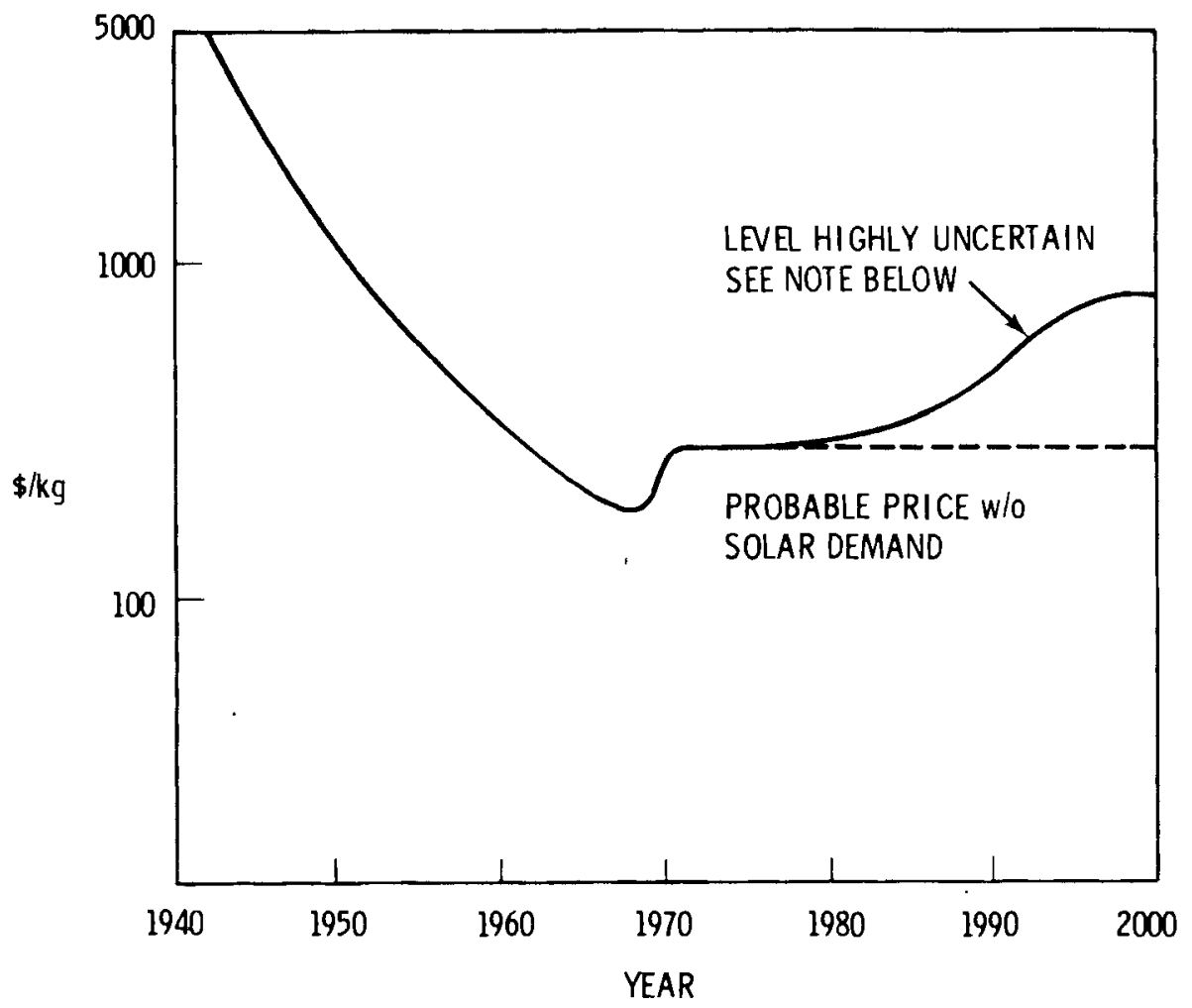

FIGURE 14. Price History and Future Price Outlook for Germanium (Data from U.S. Geological Survey Profesisonal Paper 820, p. 239.36)

NOTE: "If the price of germanium were to increase significantly, recovery of the metal from certain coal ashes would become economically feasible." (Commodity Data Summaries, 1977, Bureau of Mines, U.S. Dept. of Interior)

process for deriving germanium from coal combustion residues, and (2) concurrent R\&D efforts to eliminate or reduce the thickness of the germanium film in GaAs-MIS devices. Should the GaAs-MIS device begin to look especially promising compared to other photovoltaic alternatives, and should $R \& D$ efforts to reduce or eliminate the germanium layer look unpromising, then a much larger R\&D program to derive a low cost process to produce germanium from coal residue would be necessary.

Iron and Steel - The only concern for iron and steel is the $\$ 80 / \mathrm{KWe}$ to $\$ 82 / \mathrm{KWe}$ material cost in the systems examined. Production in the iron and steel industry is massive when compared to these designs' requirements (at 50 GWe capacity solar uses less than $1 \%$ of total steel production). 
Because of this, the price of iron and steel will depend totally on nonsolar supply and demand factors. The key question then is "Whether a significant probability exists for future price decreases in steel?" To be significant for these examples, a price decrease of $50 \%$ would be required. In the long run, this is highly unlikely because of the domestic environmental control costs, decreasing reserves of high grade ores, and the technological maturity of the industry.

Therefore, we believe that the only practical strategy is to reduce the amount of steel in the design. Since the reference design is an engineering prototype and not a commercial design, it is highly likely this can be accomplished.

Silicones - Bulk Material Concems - The primary concern with silicones is their high cost $\$ 298 / \mathrm{KWe}$ in the silicon $\mathrm{n} / \mathrm{p}$ single crystal designs (Table 6). Other concerns of lesser importance are the 10\% growth rate requirement in production capacity and the $70 \%$ of world consumption required to meet photovoltaic uses.

Silicones are manufactured from abundantly available raw materials. There are four domestic producers; they operate seven silicone production facilities at widely scattered locations throughout the U.S. Silicones are made into a wide variety of end products. Production of these products has been increasing at the rate of 15\%/year (Figure 15). Therefore, the $10 \%$ growth rate required to meet solar needs should be readily achievable.

The concentration of consumption in the solar market, however, might constrain expansion since more risk is involved in supplying a narrow market, particularly a new one in which technology changes rapidly. For this reason, we recommend undertaking periodic studies to determine the long range demand for silicones. These studies would assess the economic and technical feasibility of the solar design concepts, assess the potential market penetration, and evaluate alternative materials to silicones. If the long range demand for silicones can be reasonably assured on economic and technical grounds, then industry could be inspired to voluntarily expand capacity to meet demand. 


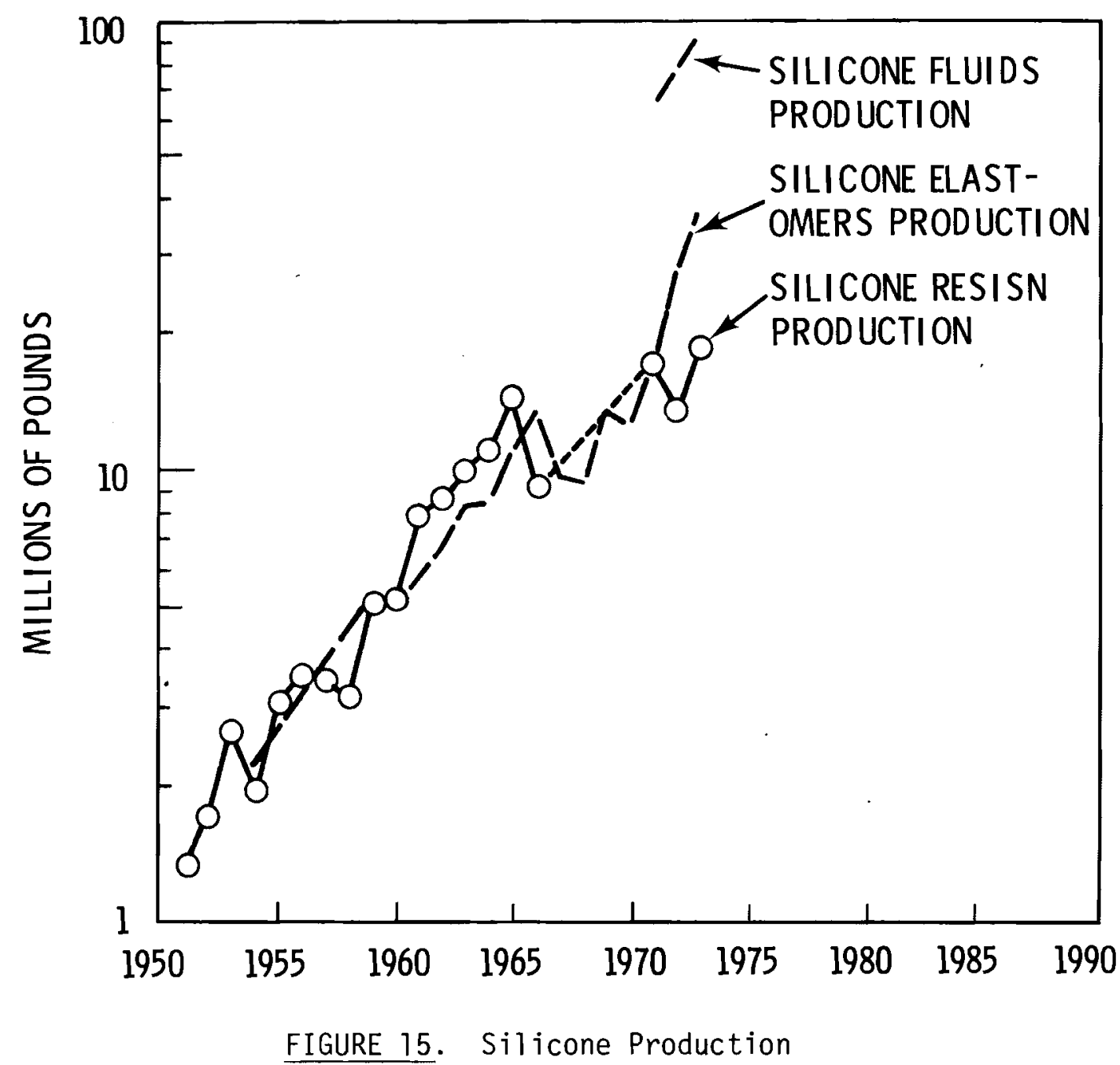

The high cost for silicones should decrease with time as technology improvements and economies of scale are achieved in the manufacture of silicones. Prices for silicone products have dropped substantially since the early 1950's when silicones were first produced commercially (Figure 16.) We project continuing price declines, but at a slower rate because the industry is maturing and because the cost of energy required in the manufacturing process is increasing. However, even with a price decline, silicones will continue to be a major cost element in this photovoltaic system design. 


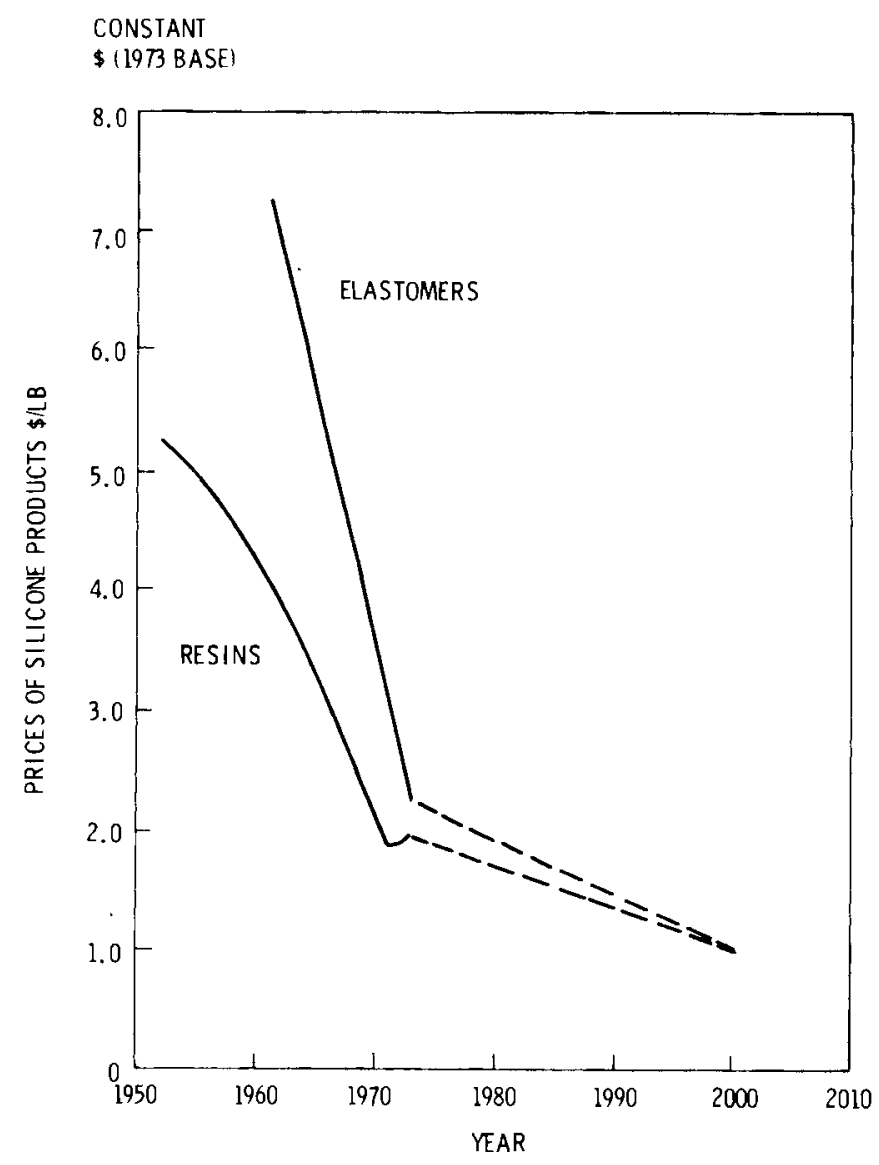

FIGURE 16. Price History and Future Price Forecast for Silicones

\section{CONCLUSIONS}

This methodology provides decision makers with a rapid and efficient determination of potential materials problems implicit in the implementation of a solar development plan. The results can be used to evaluate alternative designs, establish realistic goals, and design research programs to develop solutions to materials problems.

The usefulness of this methodology in identifying potential materials problems has been demonstrated. Future efforts will be directed toward additional data collection and analysis of materials problems for other solar designs.

An overview of key materials that could influence implementation of these two example photovoltaic systems are summarized in Table 12. 
TABLE 12. Overview of Significant Materials Problems for the Silicon N/P Single Crystal and GaAs-MIS Designs

\begin{tabular}{|c|c|c|}
\hline Materials & $\begin{array}{c}\text { Problems with } \\
\text { Photovoltaic Use } \\
\end{array}$ & Mitigation Strategies \\
\hline Aluminum & $\begin{array}{l}\text { - Large amounts of } \\
\text { Al consumed } \\
\text { - High cost per } \\
\text { peak KWe }\end{array}$ & $\begin{array}{l}\text { - Develop more Al effecient } \\
\text { designs } \\
\text { - Develop suitable substitutes } \\
\text { for Al }\end{array}$ \\
\hline Bauxite & $\begin{array}{l}\text { - Few domestic } \\
\text { sources }\end{array}$ & $\begin{array}{l}\text { - Because of the dispersed nature } \\
\text { of world supplies and the avail. } \\
\text { ability of domestic clays, this } \\
\text { does not appear to be a problem }\end{array}$ \\
\hline $\begin{array}{l}\text { Antimony and } \\
\text { Antimony Ore }\end{array}$ & $\begin{array}{l}\text { - High \% supplied } \\
\text { as a by-product } \\
\text { - } 55 \% \text { is currently } \\
\text { imported. }\end{array}$ & $\begin{array}{l}\text { - Antimony sources are widely } \\
\text { distributed and substitutes } \\
\text { have been identified. Not a } \\
\text { serious problem. }\end{array}$ \\
\hline $\begin{array}{l}\text { Copper and } \\
\text { Copper Ore }\end{array}$ & $\begin{array}{l}\text { - High cost in the } \\
\text { silicon cell } \\
\text { design }\end{array}$ & $\begin{array}{l}\text { - Develop designs with: } \\
\text { (1) higher efficiency, } \\
\text { (2) better geometric packing } \\
\text { factors, } \\
\text { (3) voltage step-up to mini- } \\
\text { mize copper wiring. }\end{array}$ \\
\hline Gallium & $\begin{array}{l}\text { - Derived as a by- } \\
\text { product of zinc \& } \\
\text { aluminum production } \\
\text { - Significant growth } \\
\text { in production capa- } \\
\text { city needed to meet } \\
\text { needs of solar. } \\
\text { - Nearly } 1 / 2 \text { of al1 } \\
\text { Ga is. supplied by } \\
\text { one country outside } \\
\text { the U.S. } \\
\text { - Current imports are } \\
75 \% \text { of domestic con- } \\
\text { sumption }\end{array}$ & $\begin{array}{l}\text { - Support R\&D into improved } \\
\text { processes for Ga recovery. } \\
\text { - Provide long-range incentives } \\
\text { and guarantees to inspire capi- } \\
\text { tal investment. } \\
\text { - Develop cell designs that mini- } \\
\text { mize Ga requirements. }\end{array}$ \\
\hline
\end{tabular}




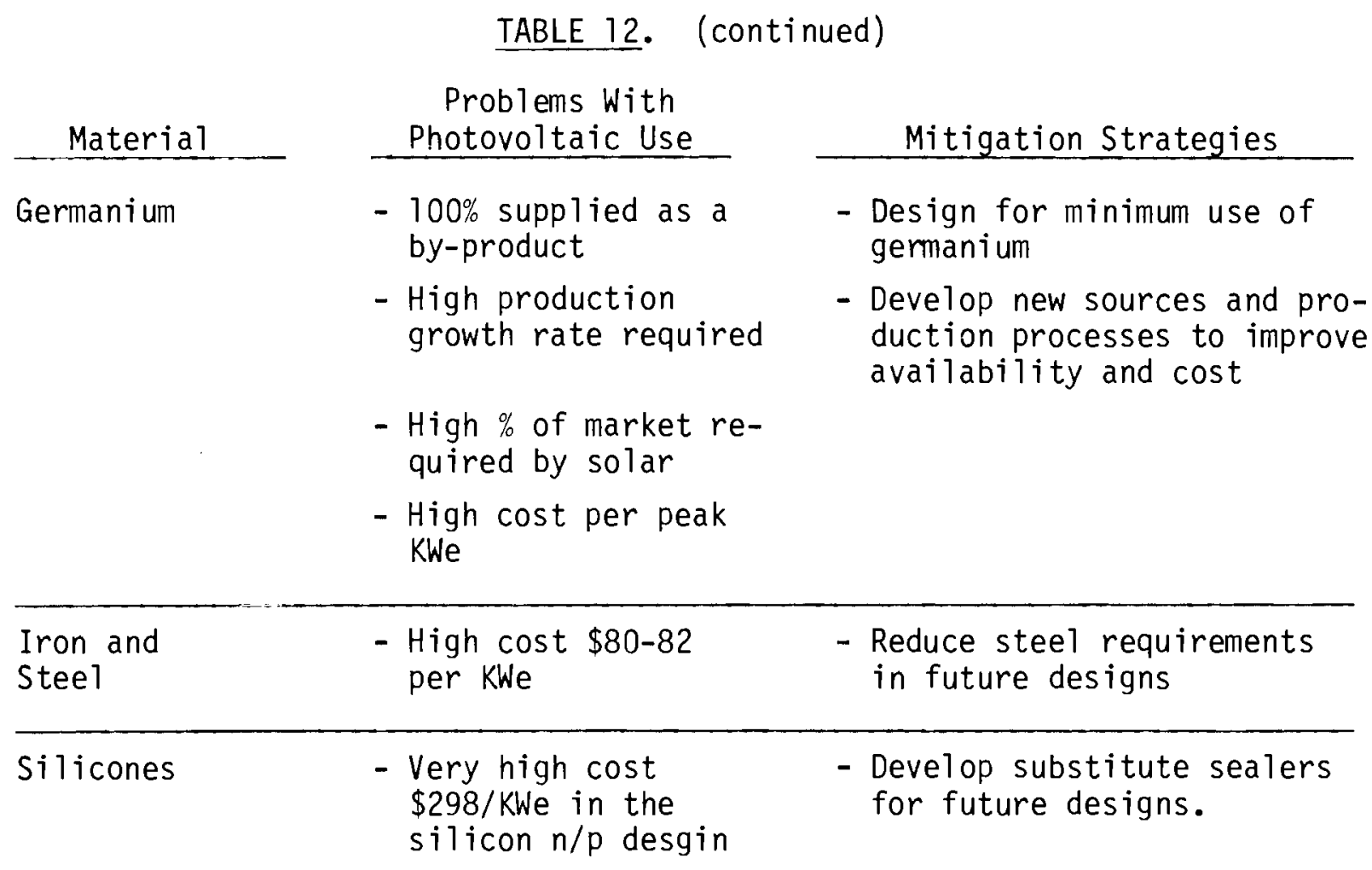




\section{ACKNOWLEDGMENTS}

In the conduct of this study contributions were made by a large number of people and organizations. Without their help, this report could not have been written.

Contributing organizations are: Massachusetts Institute of Technology's Lincoln Laboratory, Charles River Associates, and C\&D Battery.

Contributing from Battelle-Columbus Laboratories is W. L. Swager.

The following Battelle-Northwest Laboratories personnel contributed:

T. B. Correy, D. K. Davis, D. E. Deonigi, T. P. Harrington, J. S. Hartman,

E. R. Hill, D. E. Hufferd, K. E. Keene, W. T. Pawlewicz, R. P. Smith, and

J. 0 . Vining.

A special contribution was made by N. E. Carter of Battelle-Northwest. He provided valuable insights in developing the methodology and in writing this report. 


\section{REFERENCES}

1. Commodity Data Summaries 1977. Bureau of Mines, U.S. Department of Interior, Washington, D.C., 1977.

2. Mineral Facts and Problems (Bicentennial Edition). Bureau of Mines Bulletin 667, U.S. Department of Interior, Washington, D.C., 1975.

3. Chemical Marketing Reporter (Weekly)-Monday. Schnell Publishing Company, New York, NY.

4. Chemical Process Industries (4th Edition). R. Norris Shreve and Joseph A. Brink, Jr., McGraw-Hill Book Company, New York, NY, 1977.

5. Minerals Yearbook 1972: Volume 1-Metals, Minerals, and Fuels. Prepared by staff of the Bureau of mines, U.S. Department of Interior, Washington, D.C., 1972.

6. An Overview of Economic Legal, and Water Availability Factors Affecting the Demand for Dry and Wet/Dry Cooling for Thermal Power Plants. P. L. Hendrickson, BNWL-2268, Prepared for ERDA at Battelle, Pacific Northwest Laboratories, Richland, Washington, June 1977.

7. Agricultural Statistics 1972. Prepared under the direction of the Yearbook Statistical Committee: Melvin L. Koehn, Chairman. U.S. Department of Agriculture, Washington, D.C., 1972.

8. Statistical Yearbook 1973 (25th Issue). Department of Economic and Social Affairs (Statistical Office), United Nations, New York, NY, 1974.

9. Soybean: Production, Marketing and Use. Sponsored by Tennessee Valley Authority, American Soybean Association, National Soybean Crop Improvement Council, and Land-Grant Universities of Seven Valley States.

10. The World Food Situation and Prospects to 1985. Foreign Agricultural Economic Report No. 98, Economic Research Service, U.S. Department of Agriculture, Washington, D. C., December 1974.

11. E. S. Rittner, "Improved Theory of the Silicon $p-n$ Junction Solar Cel1." J. Energy. I:9, January 1977.

12. R. G. Forney, "Low-Cost Silicon Solar Array Project," Proceedings of ERDA Semiannual Solar Photovoltaic Program Review Meeting, Orono, ME, I:416, August 1976. 
13. L. W. James and R. L. Moon, "GaAs Concentrator Solar Ce11." Appl. Phys. Letters. 26:467, 1975.

14. L. W. James and R. L. Moon, "GaAs Concentrator Solar Cells," Record of 11 th IEEE Photovoltaic Specialists Conference, Scottsdale, AZ, $\mathrm{I}: 402$, August 1976 .

15. P. Voh1, D. M. Perkins, S. G. Ellis, R. R. Addiss, W. Hui and G. Noll. "GaAs Thin-Film Solar Cells." IEEE Transactions on Electron Devices. ED-14:26, 1967.

16. J. M. Woodall and H. J. Hovel, "Outlooks for GaAs Terrestrial Photovoltatics." J. Vac. Sci. Technol. 12(5), 1975.

17. Energy Use Patterns in Metallurgical and Non-Metallic Mineral Processing Phases 4, 5, and 6-Energy Data and Flowsheets, High Priority Commodities. Battelle Columbus Laboratories, Columbus, Ohio, June 27 , 1975.

18. R. N. Shreve, Chemical Process Industries, 3rd edition, McGraw-Hill, New York, New York, 1967.

19. Kirk-0thmer Encyclopedia of Chemical Technology, 2nd edition, John Wiley and Son, New York, New York, 1963.

20. C. L. Mante11, Electrochemical Engineering, McGraw-Hi11, New York, New York, 1960.

21. A. H. Leigh, "Precious Metal Refining Practices," presented at the International Symposium on Hydrometallurgy, Chicago, Illino is February 25, 1973.

22. R. N. Boyd and R. T. Morrison, Organic Chemistry, 2nd edition, Allyn and Bacon, Boston, Massachusetts, 1966.

23. M. Sittig, Organic Chemical Process Encyclopedia. Noyes Development Corporation, Park Ridge, New Jersey, 1967.

24. 0. W. Ellis, Copper and Copper Alloys. ASM, Cleveland, Ohio, 1947.

25. R. J. Miller, "Prospect for Further Processing of Selected Mineral Reserves in Developing Countries," Columbus, Ohio, May 30, 1972.

26. Lead and Zinc, Volume 1, AIME, New York, New York, 1970.

27. G. T. Miller, "Electrolytic Production oforon," Journal of the Electrochemical Society, 106(9):815, September, 1959.

28. J. L. Bray, Non-Ferrous Production Metallurgy. John Wiley and Sons, New York, New York, 1947. 
29. C. A. Hampel, editor, Rare Metals Handbook, 2nd edition, Reinhold Publishing Corporation, London, England, 1961.

30. A. Petrick, Jr. et al., "The Economics of By-Product Metals (In Two Parts) 1. Copper System." PB-220-477, Bureau of Mines, Washington, D.C., April 1973.

31 T. Tsurumoto, T. Fujii, and A. Takeishi, "Recent Development of Copper Smelting," Extractive Metallurgy Division Symposium, Denver, Colorado, February 1970.

32. Encyclopedia of Polymer Science and Technology, John Wiley and Sons, New York, New York, 1966.

33. A. Petrick, Jr., et a1., "The Economics of By-Product Metals (In Two Parts) 2. Lead, Zinc, Uranium, Rare Earth, Iron, Aluminum, Titanium, and Lithium Systems." PB-221-476, Bureau of Mines, Washington, D.C., Apri1 1973.

34. D. A. Brobst and W. P. Pratt, editors, "United States Mineral Resources," Geological Survey Profession Paper 820, United States Printing Office, Washington, D.C., 1973.

35. Perry's Handbook, 4th edition, McGraw-Hi11, New York, New York, 1963.

36. U.S. Geological Professional Paper 820. 


\section{APPENDIX A}

\section{SOLAR DESIGNS ON WHICH \\ MATERIAL REQUIREMENTS HAVE BEEN CHARACTERIZED}

Engineering and bulk material requirements for the 12 SHACOB and AIPH systems listed in this appendix have been estimated. In addition, material requirements for the 13 photovoltaic cells and one photovoltaic system have also been estimated. 


\section{SOLAR SYSTEMS CHARACTERIZATION}

\section{SHACOB \& AIPH SYSTEMS CHARACTERIZED}

Space Heating - Solaron Corporation System using $273 \mathrm{ft}^{2}$ of steel flat plate collectors - air heat transport.

Space Heating and Domestic Hot Water - Solaron Corporation System using $273 \mathrm{ft}^{2}$ of steel flat plate collectors - air heat transport.

Domestic Hot Water - Sunworks copper flate plate collectors $\left(74 \mathrm{ft}^{2}\right.$ ) - water and ethylene glycol heat transport.

Space Heating and Domestic Hot Water - American Heliothermal Corporation System using $268 \mathrm{ft}^{2}$ of steel flate plate collectors - water and propylene glycol heat transport.

Space Heating and Cooling and Domestic Hot Water - Ecosol Systems Inc. heat pump system using $258 \mathrm{ft}^{2}$ of KTA Corporation evacuated tube collectors - water heat transport.

Space Heating and Cooling and Domestic Hot Water - Kirtland Air Force Base, Exchange Main store using absorption chillers for cooling and 8320 $\mathrm{ft}^{2}$ of Raypak, Inc., flat plate collectors with aluminum plate and copper tubing - water and ethylene glycol heat transport.

Passive Space Heating - Concrete Trombe wall behind $510 \mathrm{ft}^{2}$ of glazing.

Passive Space Heating - Water tank Trombe wall behind $510 \mathrm{ft}^{2}$ of glazing.

Passive Space Heating - Direct gain, masonry walls behind $256 \mathrm{ft}^{2}$ of glazing.

Industrial Process Hot Water from Solar Ponds - Accelerates chemical leaching of uranium ore at the Sohio mining and milling complex in Bibo, New Mexica. System design by Lawrence Livermore Laboratory uses $100,000 \mathrm{ft}^{2}$ of shallow solar ponds - water heat transport.

Industrial Process Heat for Kiln Drying Lumber - Installed on a conventional hardwood drying kiln at the Linden Lumber Company, Linden, Alabama. System design by Lockheed-Huntsville Research and Engineering Center uses 2,520 $\mathrm{ft}^{2}$ of Chamberlain Manufacturing Corporation steel flat plate collectors - water and ethylene glycol heat transport.

Process Steam for Drying of Textiles at the Westpoint Peppere 11 Mill in Fairfax, Alabama - System design by Honewe 11, Incorporated uses $8,300 \mathrm{ft}^{2}$ of parabolic-trough, concentrating collectors - water and stean heat transport. 
Process Hot Water for Dyeing Fabrics at the Riegel Textile Corporation plant in LaFrance, South Carolina - System design by General Electric Company uses $5,860 \mathrm{ft}$ of G.E. evacuated tube collectors - water and ethylene glycol heat transport.

\section{PHOTOVOLTAIC SYSTEMS CHARACTERIZED}

1 Photovoltaic System Characterized for Silicon $n / p$ Single Crystal Cell Based on the Installation at Meade, Nebraska.

1 System Constructed by Modification of the Meade System to Accommodate the Different Efficiency and Packing Factor fo the GaAs-MIS System.

\section{PHOTOVOLTAIC CELLS CHARACTERIZED}

Cadmium Sulfide - Copper Sulfide Back Wall

Cadmium Sulfide - Copper Sulfide Front Wall

Cadmium Sulfide Cadmium Telluride

Cadmium Sulfide Indium Phosphide

Copper Oxide - MIS

Cadmium Sulfide Copper Indium Selenide

Silicon Single Crystal

Silicon MIS

Indium - Tin Oxide

Tin-0xide-Silicon

Amorphous Silicon

Gallium Arsenide, Concentrator Cell

Gallium Arsenide - Thin Film Cell

NOTE: Additional Photovoltaic System Characterizations will be Required to Evaluate the Cells which need Concentration of the Sunlight at Various Levers. 


\section{APPENDIX B}

BULK MATERIALS DATA BASE

This appendix includes the data used to analyze each of the buik materials in this report. Some of the information in this Appendix is in computer format due to space limitations. All consumption estimates are in metric tons. 
$31 \cdot M 194-78$

MATERIFIL $\because$ SUPFLIED NHFHE

$\because$ SUFFLIED -

FLUHINUW

RSEESTOE

EOROT!

CEMENT

CHEÚt IUH

CORL:

GFLLIUH

GEFATFR:IIN

GLF

GLASE. FIEEFE

GLASS, SULA LIME

IFOR, STEEL

LEFD

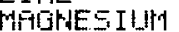
FEFPOIARUGFNESE

NACLEL

PHOSFHOROUS

SAMD $\triangle$ GRAYEL

STUR.

SILICOR

ILYEF

SULFIJPIE: RIID

TFENTFLIU

TIN

TITHNI!H

STHINLESS STEEL

PIO IROM

FEREUCHFOME

INSEED OIL

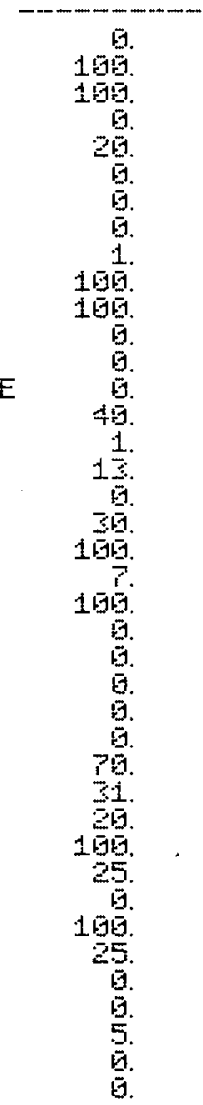

WOEL HOFL

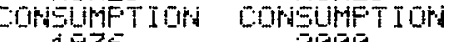
MILLIOHE WT MILUTES HT

LAFGET Nom

$\underset{\text { FFIEE }}{\text { FMT }}$ is

FERTLIL

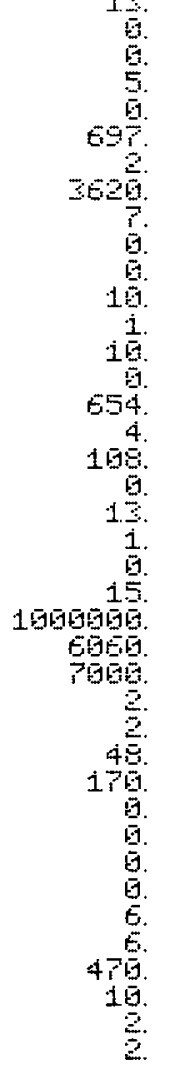

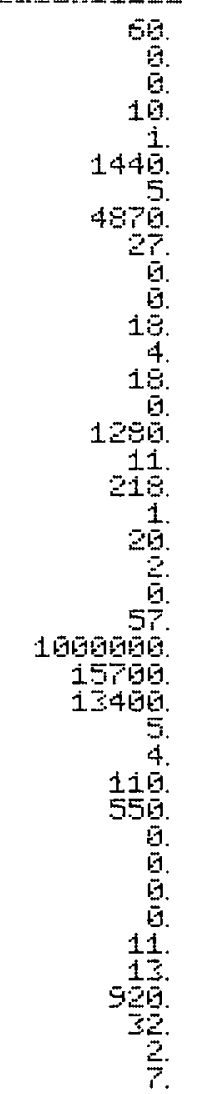

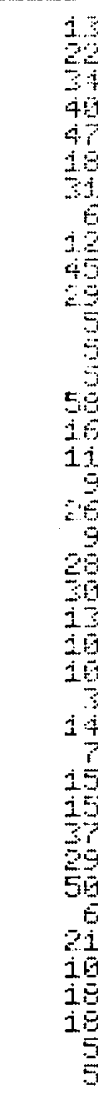

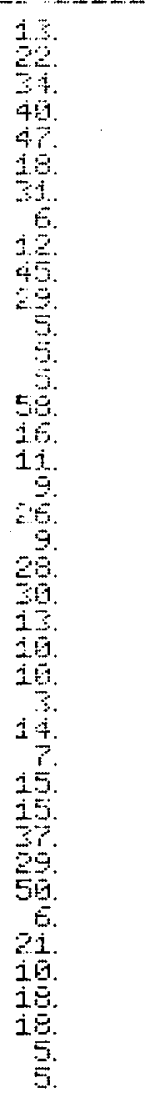

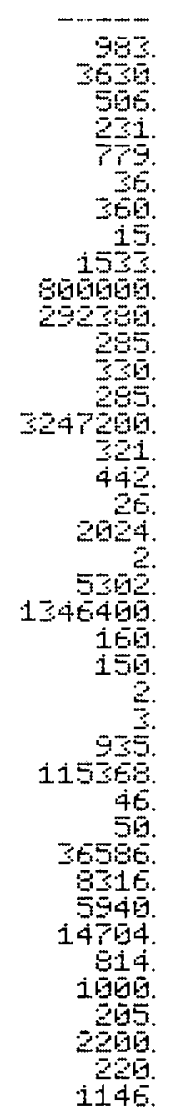

PESTET PEFTETEQ

FHIIE $\quad i$

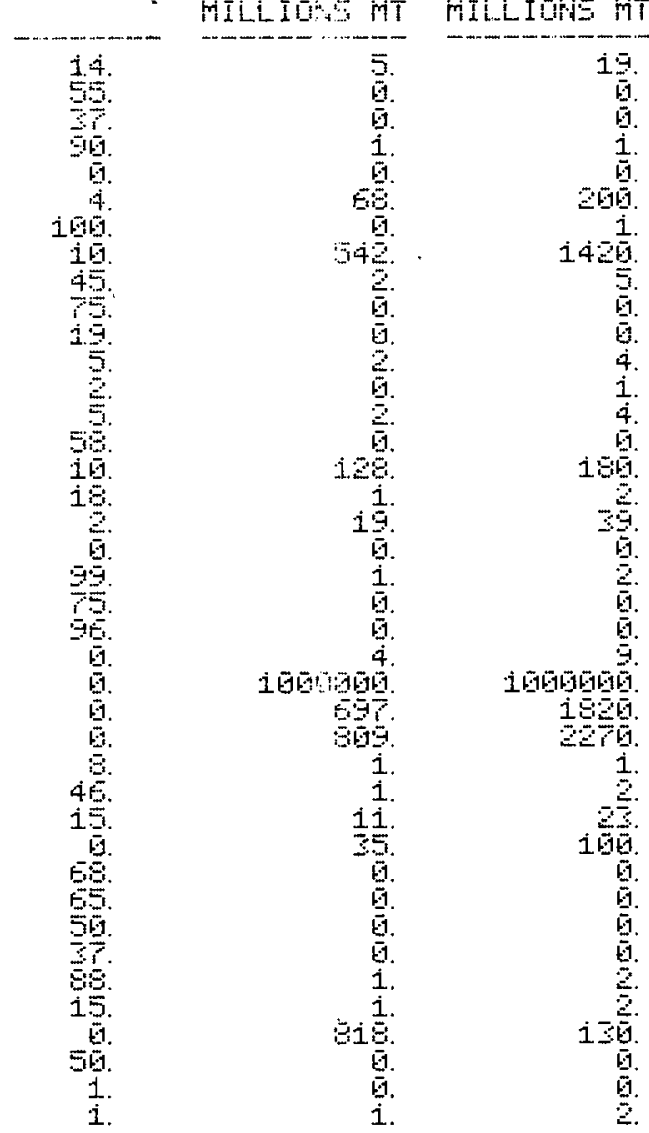


EIJLK MATERIFL DATA SIJMMARY

31-MFY-PE

\begin{tabular}{|c|c|}
\hline $\begin{array}{c}\text { MFIEFIIFL } \\
\text { NATHE }\end{array}$ & $\begin{array}{l}Z \text { SUPFLIED } \\
\text { ASE } \\
\text { EY-PROLUCT }\end{array}$ \\
\hline 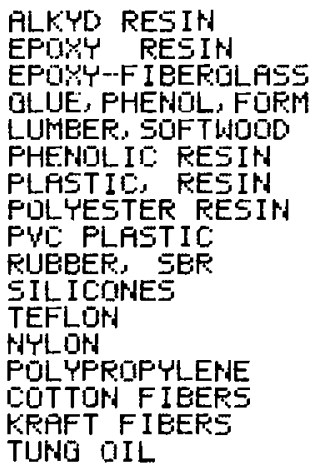 & 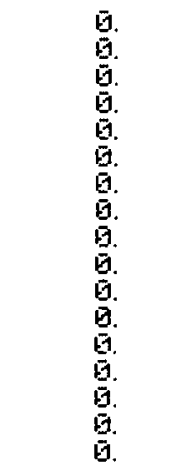 \\
\hline
\end{tabular}

\begin{tabular}{|c|c|c|}
\hline $\begin{array}{l}\text { WURLO } \\
\text { CONSUMFT ION } \\
\text { MIITE } \\
\text { MILLIOHS NTT }\end{array}$ & 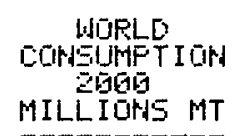 & 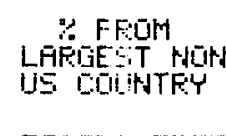 \\
\hline 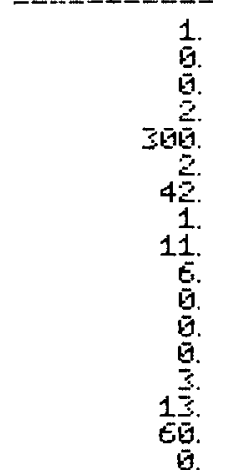 & 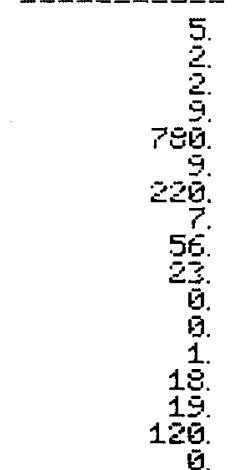 & $\begin{array}{r}5 \\
5 \\
5 \\
20 \\
5 \\
5 \\
5 \\
5 \\
5 \\
5 \\
5 \\
16 \\
16 \\
45\end{array}$ \\
\hline
\end{tabular}

FFIIE 2

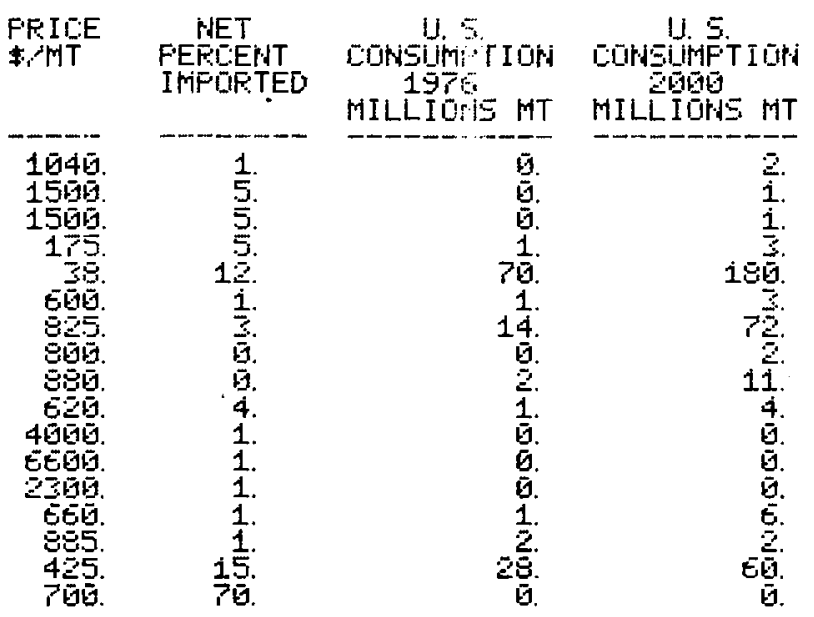




\section{APPENDIX C}

RAW MATERIALS DATA BASE

This appendix includes the data used to analyze each of the raw materials in this report. Some of the information in this Appendix is in computer format due to space limitations. A11 consumption estimates are in metric tons. 
F.HW WFITEIFL OATH SUMWAFY

F"HIJE $i$

RNT IMONY DRE ARSENIC TPIOWID

ASBESTOS

EFRITE

EALLITE

EDRATE

CHPOHITE

CLAYS

COAL

COPFER OPE

FLUOFEPAR

OLU

OUESUM

IRTMN ORE

$?$ LEFD

LEFD DRE

MFNGANESE ORE

NICKE ORE

I TRUGEN, $F$ I $M E O$

PETRULEUT

PHOSPHATE ROCK

PROPHNE

RUTILE

SALT CORAYEL

SILUER ORE

ETOH.NE

THRTTHLUM DRE

TIN ORE

TUNGSEN ORE

CINC ORE

MLFH SEED

HOFLE HOFLE FRILE RE FEW 19PE MT

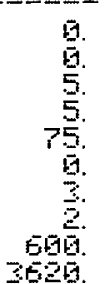

9

- - - -
WOFLO MILLION WILLIUNS MT$$
\begin{array}{r}
0 \\
15 \\
246 \\
2410
\end{array}
$$

240.

1
5
5
5

964.
498.

$48 ? 6$. 3096.
505.

$21=$ 궁․ 25.

15.

gegs.

?

??

14.11

$11 \stackrel{5}{3}$

87

114.

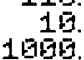

1 G65.

1030.

21 .

563

$\begin{array}{rl} & 48 . \\ 2 & 186\end{array}$

4114

414.

130
$6 \Omega ?$

$16 ?$

GEE.

15200

114. 115

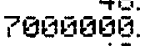

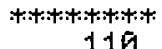

110.
6
6
6
11
19
3

$$
\begin{aligned}
4 E \\
265
\end{aligned}
$$

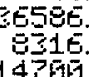

$\begin{array}{rl}14 & 7015 . \\ 814 .\end{array}$

814.159

160. t.t.t.t.t.t.t.t.t.

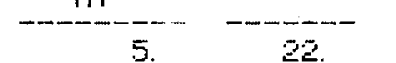

LAFGEST

TOF $\Xi$ COUNTRIES
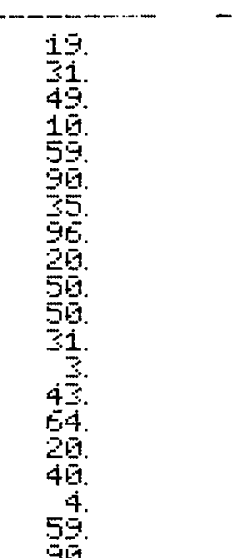

NET I TPFORTED

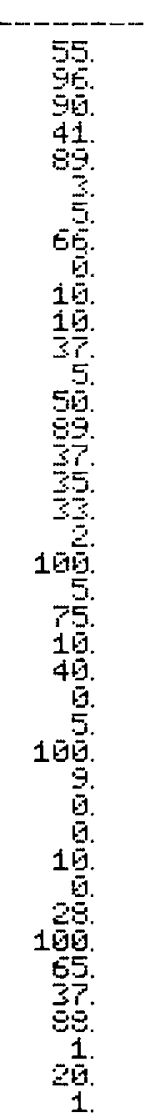

11.5

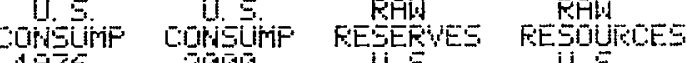

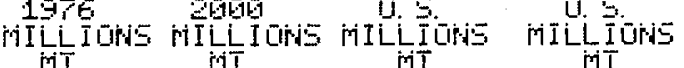

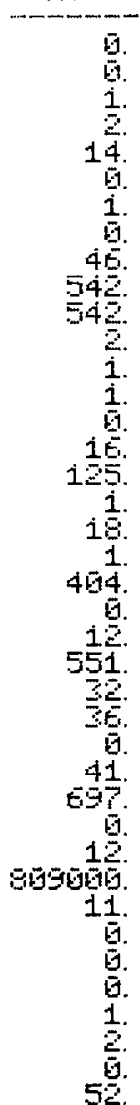

$$
\begin{aligned}
& \text { - ला } \\
& \text { 夏 } \\
& \text { iet. } \\
& 140
\end{aligned}
$$$$
\text { 円ILL }
$$$$
\text { 円I I L }
$$

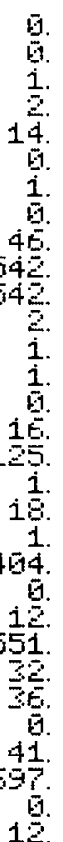

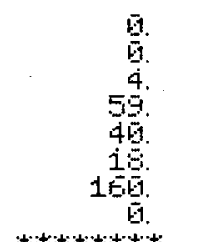$$
\frac{5}{306}
$$

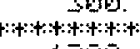$$
130 .
$$

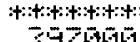

30

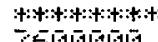
EGT

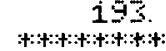

3.

$+\cdots+\cdots+\cdots+\ldots+\cdots+\cdots+\ldots$ ibs.

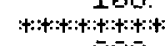
410.96.

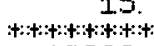
1601010. Ext

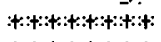

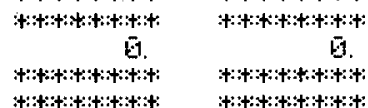

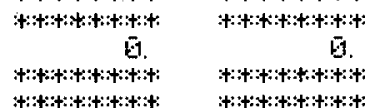

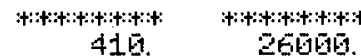


FAM MAIERIAL DATA SUNHARY'

I-MAT-PE

\begin{tabular}{|c|c|c|c|c|c|c|c|}
\hline $\begin{array}{c}\text { MATEEIIIL } \\
\text { NHTE }\end{array}$ & $\begin{array}{l}\text { WOELE } \\
\text { COHEUtiF } \\
19 \text { GE } \\
\text { MILLIONS } \\
\text { MT }\end{array}$ & $\begin{array}{l}\text { WOFLD } \\
\text { CUKSUMF } \\
\text { MEGG } \\
\text { MILIUNS } \\
\text { NT }\end{array}$ & 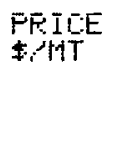 & $\begin{array}{l}\text { RAD } \\
\text { RESEREES } \\
\text { WURLD } \\
\text { MILLI IHS } \\
\text { miT }\end{array}$ & 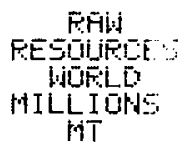 & 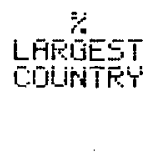 & 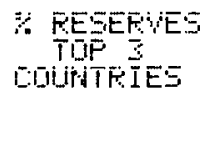 \\
\hline 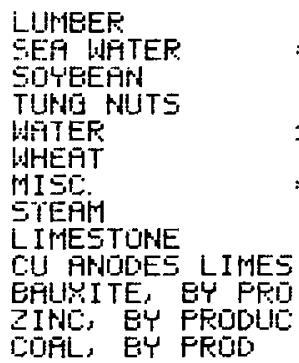 & 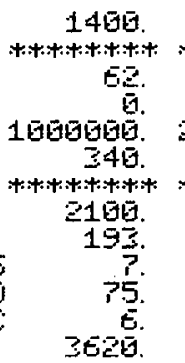 & 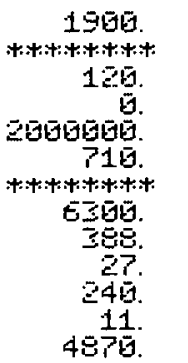 & 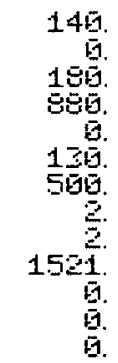 & 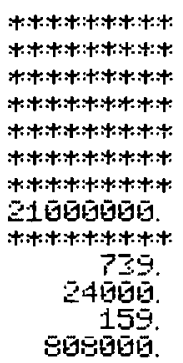 & 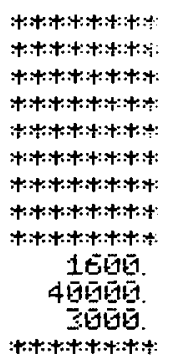 & 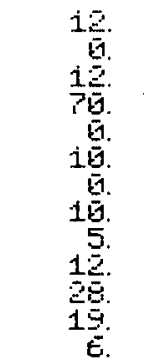 & 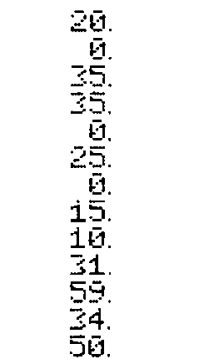 \\
\hline
\end{tabular}

INE, EY FRODUL

$36 \bar{C}^{2}$

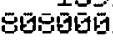

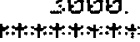

FPALE

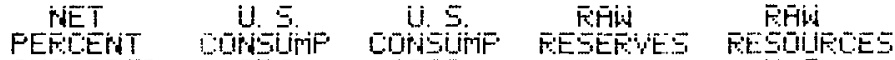
I HFUTETED भILLTIOHS MILLIORS MILL

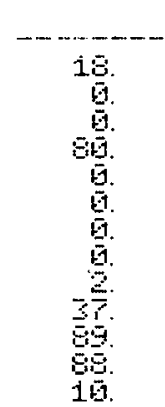

-iv $5+16$
31 Bg.

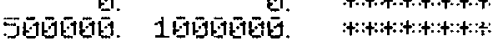

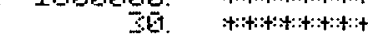

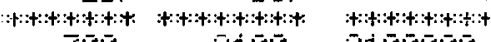

7घ.
54. 


\section{APPENDIX D \\ CONVERSION FACTORS FOR \\ BULK TO RAW CONVERSION}

This Appendix includes the results of process analysis and shows the number of metric tons of each raw material necessary to produce one metric ton of each bulk material. 
BULK HATEFIAL : FLUMINUA FAH MATTERIFLS
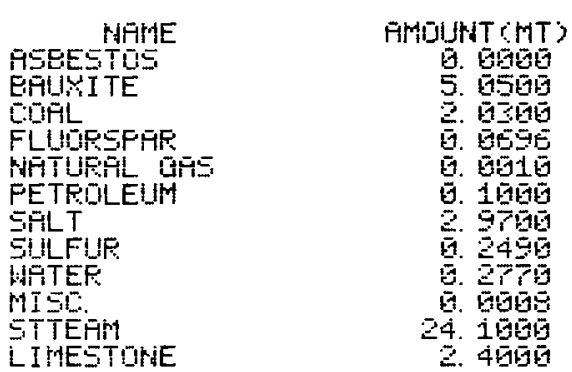

BULK MATERIAL : FNTIMONY FËW MATEFIALS

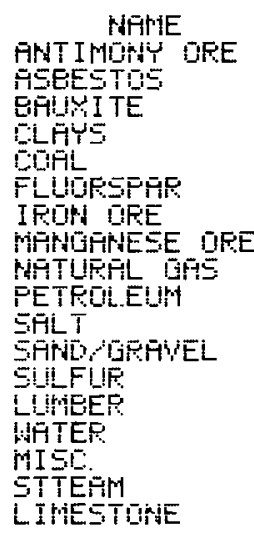
FMOULAT CMT? i.65. 84019
‥ 9245
6. 15102
6. 5901
i. 8650
6. 1961
G. $14 . \overline{10}$
6. 616
घ. 9160
a. 5100
43. 501610
ต. 4196
ต. 1 जि
6. 9010
3. GeG6
5. ब190
71. 26010
2E. SEG

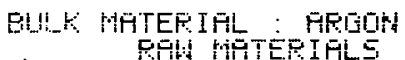
PAH WHTEIFLE NHTE

MMUUस

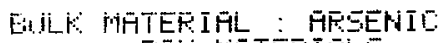
PUA, WHTERTHE

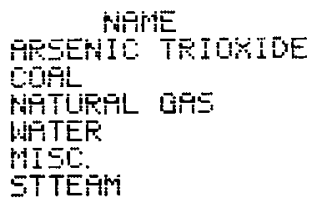

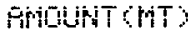
i. Elates
6. 4 구부
ธ. 0506

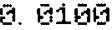
6.
b. 1560

BULK MATERIAL : MSEESTUS FIIA HITERTEL RSEESTISE

FMDUNT (NT) 1. 50105

EULK MATEFIFL : EFRIUM FEH MATERIFLS NAWE

FHTOLNT (MT)

BULK MATERIAL : EERYLLIUM FFH MATERIFLS

NAFHE

FีMÜUNT CMT?

EUII.K MATEFIAL : EISMITH REV RITERISLS

MigME

FMULNTERT

EULK MTEFIEL : EOEOA REIA NETER IELS

\begin{tabular}{|c|}
\hline 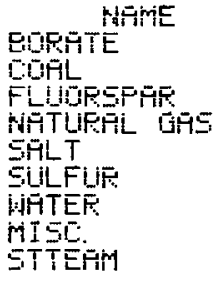 \\
\hline
\end{tabular}

FriDUNT CMT

T. 5565

6. 6160

24. 969

a. $5 \geq 06$

i64. 6065

i.ร. 96615

i

ติ.

$7 \unlhd .5090$

BULK MATERIFL : ERONITNE PAW MATERIALS

PATME

FMUUUNT CMT)

EULK MATERIAL : CAOMIUM FËW MATERTIFL

THFITE

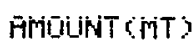




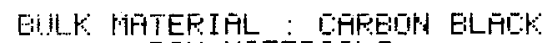

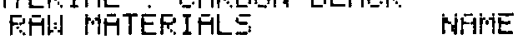

Fimoukit (RiT)

BIHL RATEFIFL : CEREHT PAH MATECI IGL

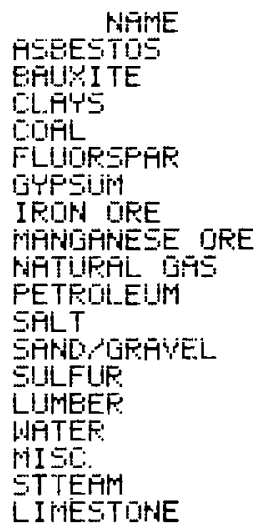
FMIUNT (MT)
6. 01965
ธิ. ติธิธย
ต. 1450
ㄷ. 693
ㄷ.
ㅂ. 9486
อ. อิธ5อ
ㄷ. อง
ธ. 655
9. $06 \overline{109}$

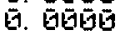
ต. $65 \% 6$
ธ. อิติธต

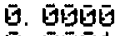
E. ET1
ธ. อิติธติ
ธ. 5011
1. ะ๐ต

EHLK MFIERIAL : DESIUUM

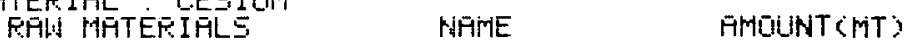

SULK PITTEPIAL : CHROHIUM FAH MATERIALS NGME

FMIJUNAT \&MT

26006

EIILKF MATTERIFL : ELATYS RAMU HATTERI ILSS NATME

ATHOUUNT (MT)

ELLL RATERIFL : COEL, GNTHRALITE PRIA MÄTER I FLLS NAME

FMOUNT (MT)

BULK MATERIAL : GOAL, EITUMINUUS FIA MUTERIALS DOAL EITUMALIONT

FMOUNAT (MT)

1. $\overline{6} 10 \overline{0}$

BILK MATERIAL : COEALT RFH MATERIFLS NATHE

FMOUNT (NT)

EIILK MATEFIFL : EILLLPEIUM

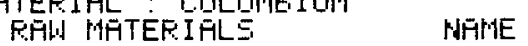

FHIDUNT SMT:

EHILK MATERIFL : COPFER FALA MATTER I GLS

\begin{tabular}{|c|}
\hline 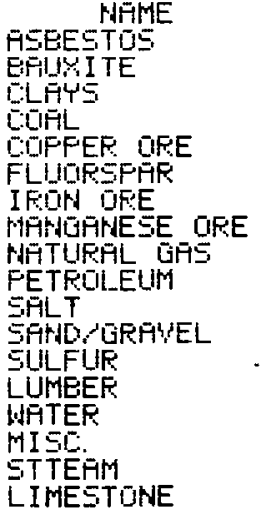 \\
\hline
\end{tabular}

RMŪUNT CMT)

ธ. 5690

․ GETI

G. 6141

E. 4415

220. 9696

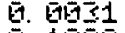

‥ 1 है⿴囗十

6. 9605

6. 5140

‥ 6139

0. 50105

5. 19064

6. $055 ?$

ต. 9059

4. PPG

ธ. 2885

ธ. $5 \overline{7}$

ต. 3546

EULK MATERIFL : COIRRUNDUM RAW MATERIFLS NAME

RMUUUNT (MT)

EIILK MATERIAL : [IAMOND FFIN MIFTERIFLS NAME

FMUUNT (MT)

BIil_K NHTERIFL : DIATOMITE FF̂W MATTERIFLS NIME

RMMUUNT (MT) 


\begin{tabular}{|c|c|c|c|}
\hline EULL & 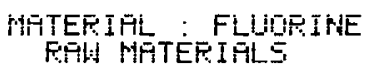 & MFIME & FMDUNT (HT) \\
\hline ULK & $\begin{array}{l}\text { MATEFIATL : GRLLIUH } \\
\text { PRTH HATEFIFLS }\end{array}$ & 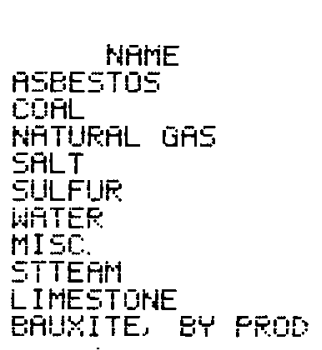 & 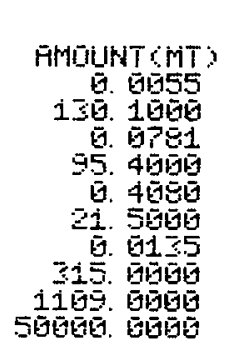 \\
\hline EULt. & 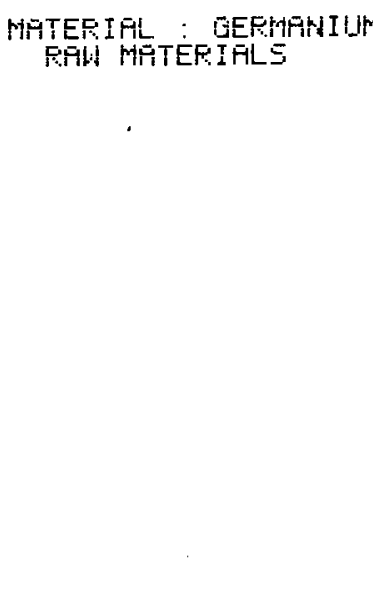 & 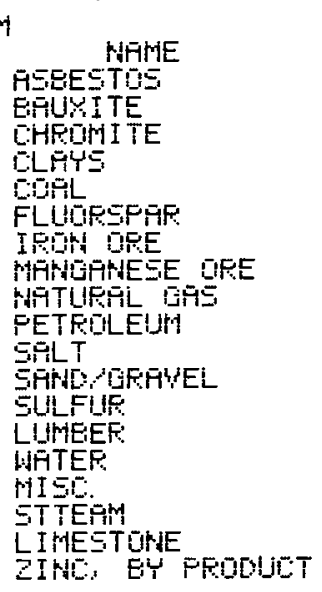 & 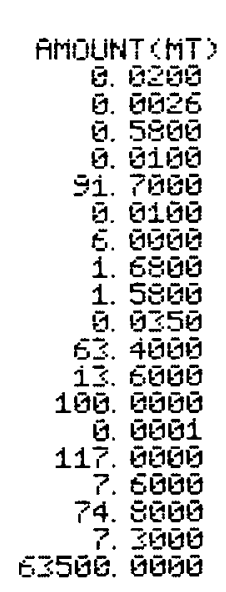 \\
\hline EIILF & $\begin{array}{l}\text { MATERIFL : EREFHITE } \\
\text { FIH WHTERIALS }\end{array}$ & NAFHE & FMOLUNT CHT) \\
\hline EULK & $\begin{array}{l}\text { MATERIFL : OYFSIJW } \\
\text { PFW PIFTEFIFLE }\end{array}$ & NAMTE & FMLOLNT (MT) \\
\hline EULLK & $\begin{array}{l}\text { MATEFIIAL : HEL IUM } \\
\text { PRIA MATERIFLS }\end{array}$ & MFIME & RMUUNT (MT) \\
\hline EULKK & $\begin{array}{l}\text { MATEFIRL : HYOFOUIEN } \\
\text { FAW MTTERIFLS }\end{array}$ & NHF̈LE & FMOUUNT (MT) \\
\hline EIILKK & $\begin{array}{l}\text { MATEFIFL : GLATSS } \\
\text { RAIV MATERIALS }\end{array}$ & 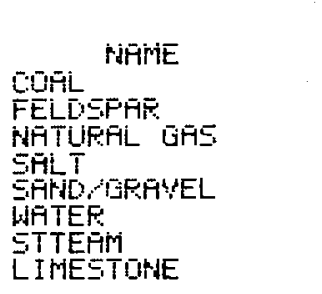 & 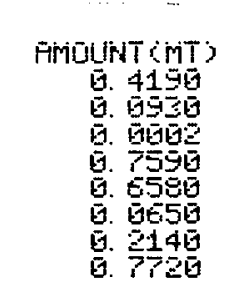 \\
\hline EUtulK & 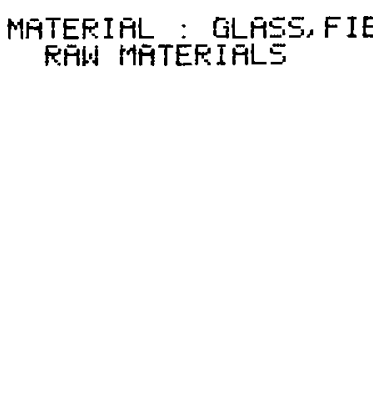 & 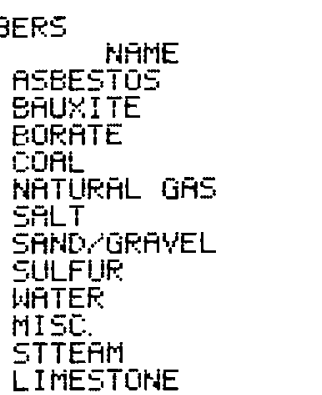 & 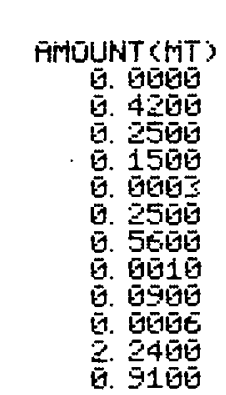 \\
\hline
\end{tabular}




\begin{tabular}{|c|c|c|c|}
\hline 대능 & $\begin{array}{l}\text { METEIFI : GLFSS. } \\
\text { RAH MATERIFLS }\end{array}$ & 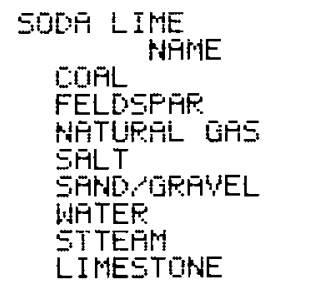 & 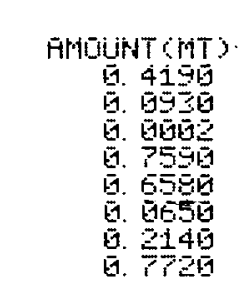 \\
\hline Eitilitic & MUTEFIAL : GQLO & 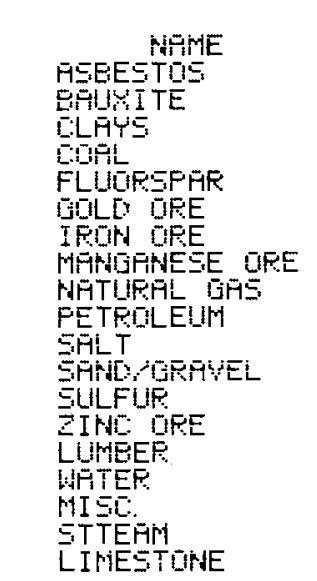 & 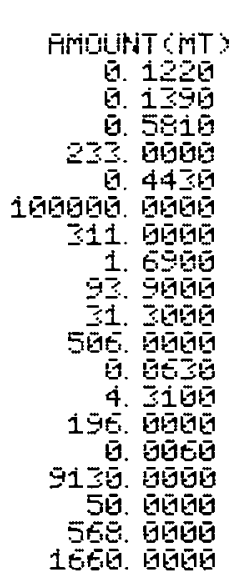 \\
\hline EIILK & 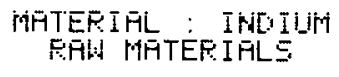 & RAERE & AROUNT SHT \\
\hline 댄는 & $\begin{array}{l}\text { MPTERIAL IOLINE } \\
\text { PGH MPTER I HLE }\end{array}$ & PHIMEE & FMDULAT (RT) \\
\hline EULLK & 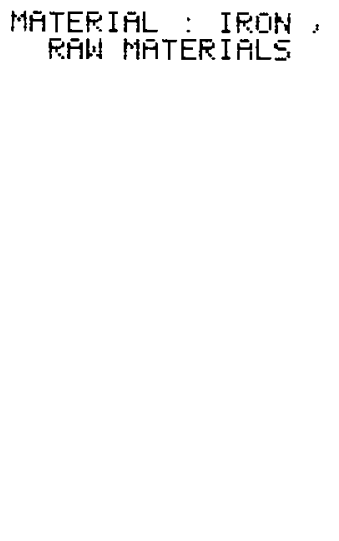 & 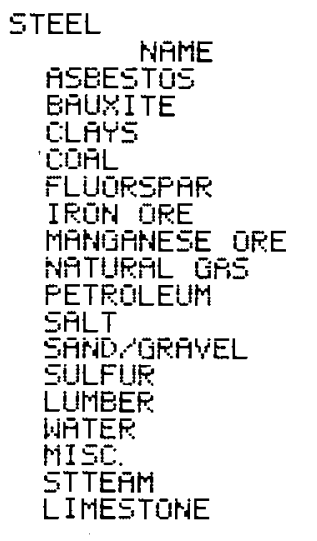 & 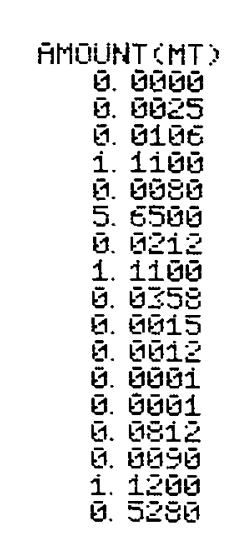 \\
\hline ButK & $\begin{array}{l}\text { WFTEEIAL : LEFE } \\
\text { RFH MHTERIFLS }\end{array}$ & 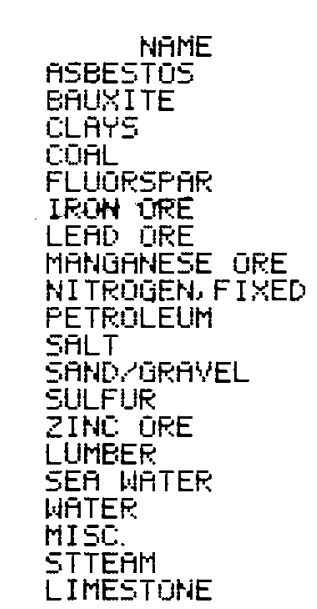 & 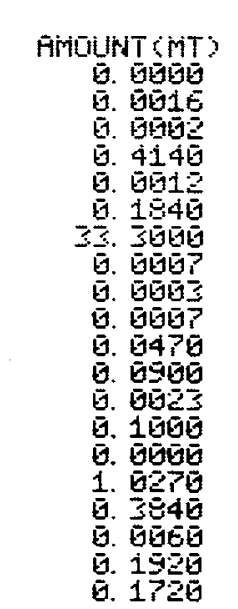 \\
\hline
\end{tabular}




\begin{tabular}{|c|c|c|c|}
\hline iL & MTEFIFI L LITE & 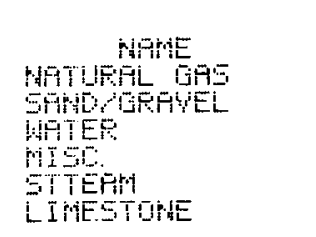 & 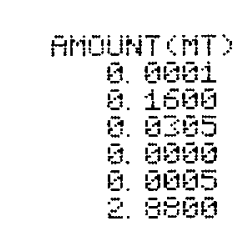 \\
\hline Buik & 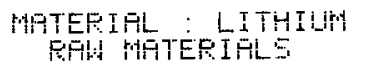 & HHE & Griout TCMT \\
\hline DUण.L & 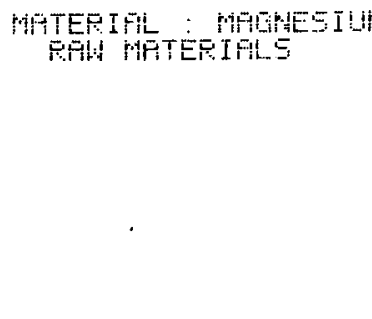 & 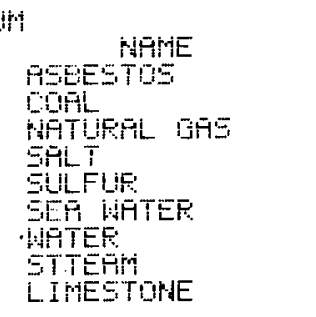 & 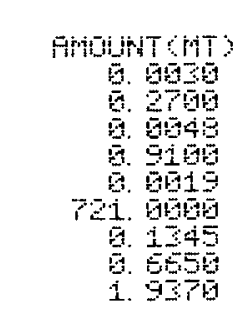 \\
\hline EILF: & $\begin{array}{l}\text { MATEEIAL : FECFOHER } \\
\text { PFH HATEIALS }\end{array}$ & 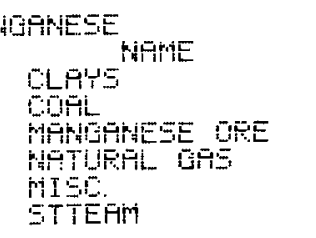 & 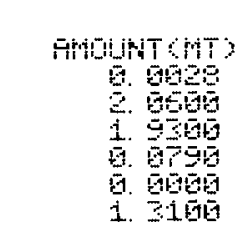 \\
\hline Euitr & 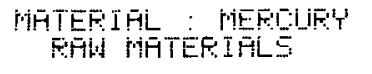 & NAATHE & Frngunt CMT \\
\hline EHIL & 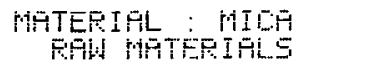 & MATriE & 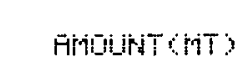 \\
\hline EUHK & $\begin{array}{l}\text { METERIFL : WOLYESEH } \\
\text { FHA MHTESIFLE }\end{array}$ & MAFHE & FIOULIT GIT) \\
\hline BuLK & HTERIAL : NATURAL & MAIIE & 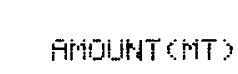 \\
\hline Buink & 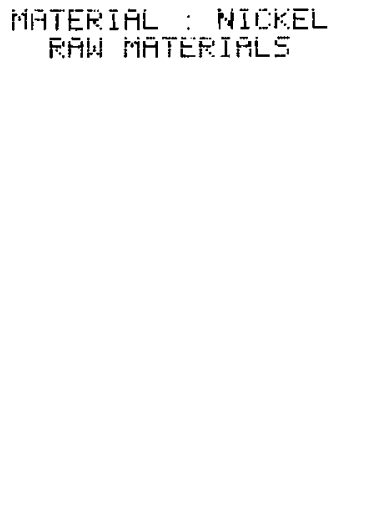 & 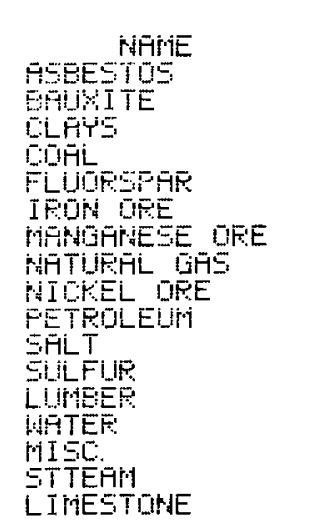 & 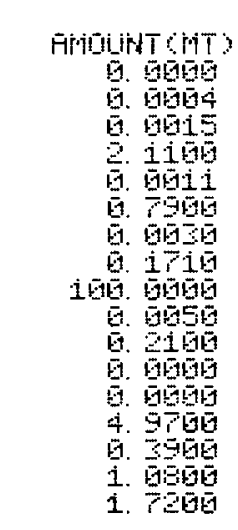 \\
\hline EULK & 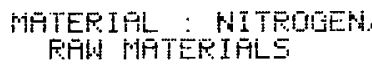 & FISED PARME & ARILURT CMT) \\
\hline EuLL゙ & $\begin{array}{l}\text { MTERIAL : THEGEA. } \\
\text { FHW MTERIFLS }\end{array}$ & RAFPIC & FHOUNT \\
\hline EULLK & $\begin{array}{l}\text { METEFIAL : PALLFOIUA } \\
\text { PAW RIATERIFLS }\end{array}$ & 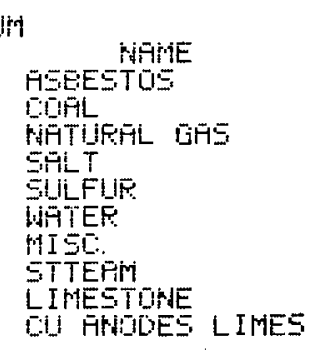 & 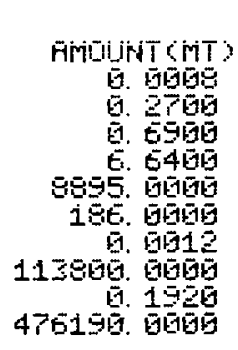 \\
\hline
\end{tabular}




\begin{tabular}{|c|c|c|c|}
\hline BijL & $\begin{array}{l}\text { MATEFIAL : FEAT } \\
\text { FHW MATERIALS }\end{array}$ & RiATHE & FHOUNAT (HIT) \\
\hline BULY & MITETIL : FEFLITE & NAFite & Enitint ChT? \\
\hline EULK & $\begin{array}{l}\text { MATERIFL : FETROMHE } \\
\text { PRW WHTERI ILS }\end{array}$ & EMILALS & 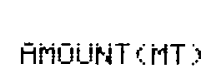 \\
\hline EULLKK & $\begin{array}{l}\text { MATEFIFL FHOSFHOF } \\
\text { RFH WHTE IFLS }\end{array}$ & 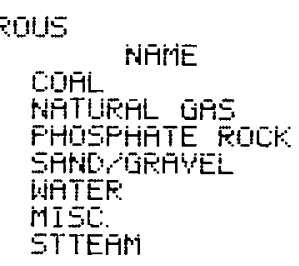 & 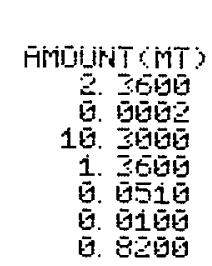 \\
\hline Biils & TUATEFIAL : PLATIPAH & PHETEE & FríLNTCHT) \\
\hline EULL: & 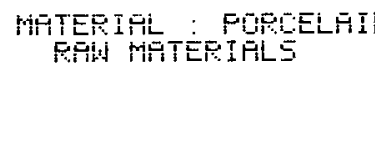 & 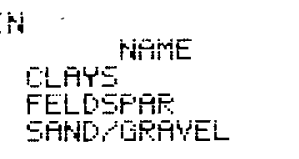 & 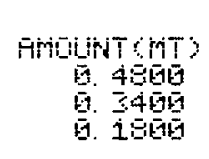 \\
\hline EULLK & 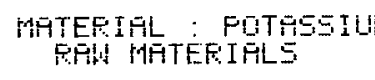 & MANME & AMOLLT (NT) \\
\hline 래난 & 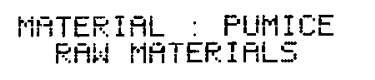 & RHEHE & AMGUAT (MT) \\
\hline BiiLŕ & 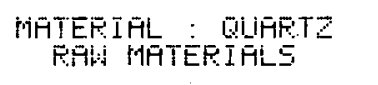 & MHEDE & FHOLNT CHTS \\
\hline BuLt: & $\begin{array}{l}\text { MATEEIAL : FHOIUN } \\
\text { FEH FIATEFIFLS }\end{array}$ & KHETHE & ARIOLINTSTS \\
\hline BULK & $\begin{array}{l}\text { MATERIFL : RHENIUA } \\
\text { FHA WRTERIFLS }\end{array}$ & $\mathrm{KJEHE}$ & Frtoilkit Cints \\
\hline EItL_t & MATEFIAL : FUEIDIUM & MABHE & AHOUNT CMT) \\
\hline Bitik & MHTEFI I L : SALT & NETIE & FMOULATCHT) \\
\hline Euth & $\begin{array}{l}\text { MATEETAL : SARE \& GH } \\
\text { PAH MATEFIFLS }\end{array}$ & $\begin{array}{l}\text { FEUEL } \\
\text { EARID, RAFHEVLEL }\end{array}$ & 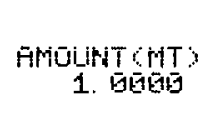 \\
\hline BUUடト & $\begin{array}{l}\text { MATEFIAL : STORJE } \\
\text { FAH MTEROIFLS }\end{array}$ & 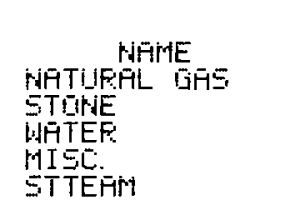 & 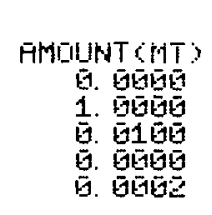 \\
\hline ㄷUㄴㄴㄴㄴ & 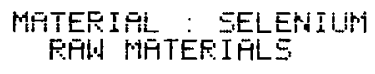 & RIATE & AMUUUNTCMT) \\
\hline Eiil_r & PIATEFIAL : GILIEONA & 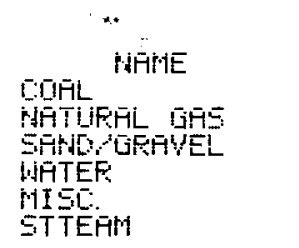 & 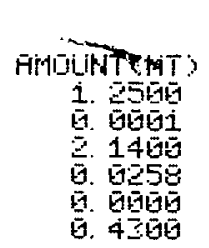 \\
\hline
\end{tabular}


EIILK HATEEIFL : SILYEF PRW MATEFIALS

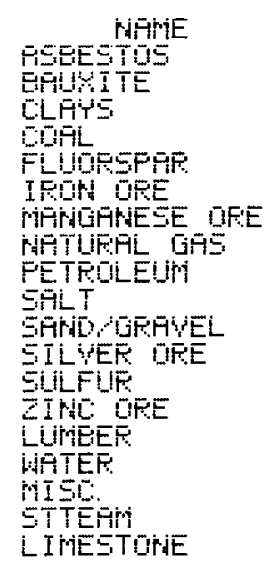

FIOLINTCMT)

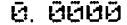

a. 6945

6. 1516

7. $7 \mathrm{Bg}$

6. 6121

G. $74 \overline{5}$

5. 5446

2.

2. 4500

ร. 5590

6. 6920

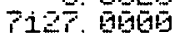

i. $60^{\circ} \overline{0}^{\circ}$

320

6. 9018

52.

i. 2366

12. 5060

1\%. 4960

BULK MHTEETAL : EDIUH

RIPIE

FinOLikT (MT)

BULK FITERTAL : STRONTIUA

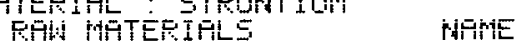

FMOUNT (HT)

EALF MHTEFIFL : SUILFUR:

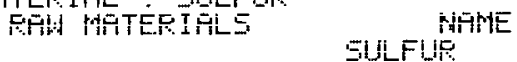

AMDUNT CMT?

1. 16015

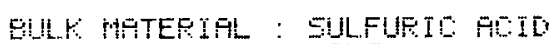

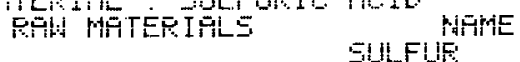

FHDIGTETS

․ 24010

DULL MATEPIRL : THLE

FOH MUTERTEL NADE

FHDUAT CATs

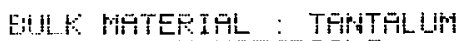
PEH HFTEEIALS

\begin{tabular}{|c|}
\hline 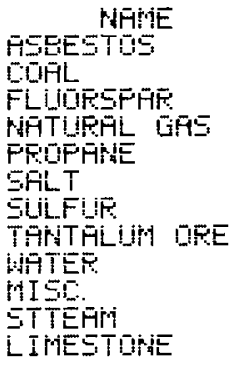 \\
\hline
\end{tabular}

FFOUNT (MT)

9. 9198

2. 4 जिए

4. 8000

5. 9053

5. $0 \geq 05$

51. 4016

$21=61$

ㄷํ. 0196

1. 43019

6. 921

ㄹ. ำ

2. 2160

EALLK MATEFIAL : TELLIIFIIIM FAW MATERIFLS PARTE

FHULATET)

BULK MATEFIFL : THFLLIUST RAW HATETIFLS

MATIVE

FMiLikT CAT)

BULK MATERIFL : THOEIUM

PENW MFTTERIALS NAME

FIVILIRT EMT)

EILK MATEFIFL : TIN

MEME
CLAYS
OORL
TIM OEE
LIMESTONE

FMUUNTEN?

E. 1690

6. 2350

10060 .

6. 6476 


\begin{tabular}{|c|c|c|c|}
\hline Eilit.K & $\begin{array}{l}\text { MHTER I HL : TITANIIIM } \\
\text { PRAN MATEF I FLS }\end{array}$ & 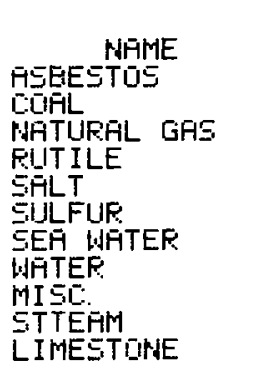 & 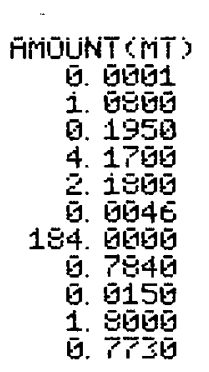 \\
\hline EUILKK & $\begin{array}{l}\text { MATER IFL : TLNHESEN } \\
\text { FFH MATER IFLS }\end{array}$ & 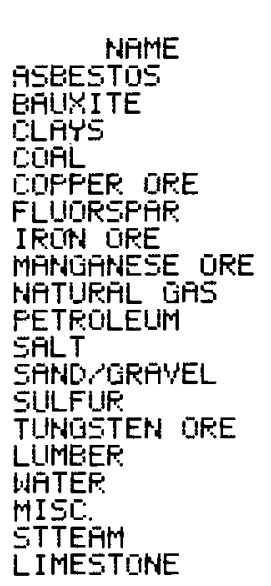 & 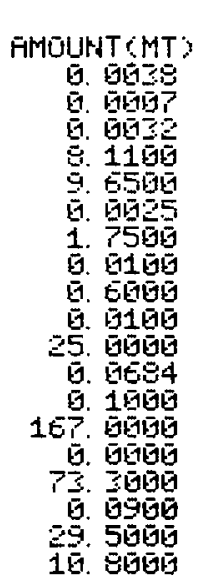 \\
\hline EULKK & $\begin{array}{l}\text { WATEFIFL UFFNIUM } \\
\text { FAW MATER I HLS }\end{array}$ & NAMME & FMUUNT \&MT? \\
\hline EULK & $\begin{array}{l}\text { MATEFIFL : VRHFDIUM } \\
\text { RAW MFTER IAL }\end{array}$ & NATME & FMOUNT (NT) \\
\hline EuLtKK & $\begin{array}{l}\text { MATTERIFL : YEFHILIL } \\
\text { RAW MFTERIALS }\end{array}$ & NAMME & FHAUUUNT CMT: \\
\hline ELILK & $\begin{array}{l}\text { MA1ERIFL : WATER } \\
\text { FHAU MATERIALS }\end{array}$ & NFIME & FMÖUNT (MT) \\
\hline EIIL.K & $\begin{array}{l}\text { MATERIFL : YTTEIUM } \\
\text { FFW MATEF I ILE }\end{array}$ & NFWE & FHOUNT CMTS \\
\hline EULK & MATEFIFL : ZINL: & 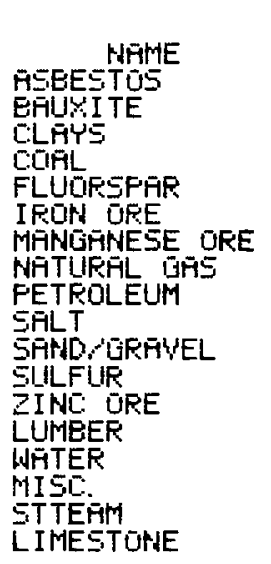 & 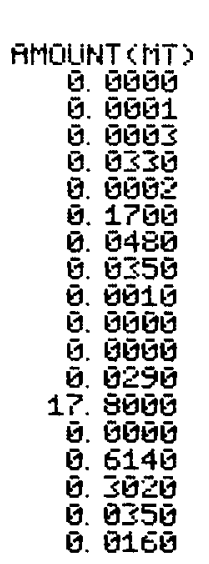 \\
\hline EULKK & $\begin{array}{l}\text { MIFTERIFL : IREONNI } \\
\text { RTHW MATERIALS }\end{array}$ & tif & F̈rüUNT \\
\hline
\end{tabular}




\begin{tabular}{|c|c|c|c|}
\hline EUI_L & WTERIFL : STEIHLES & 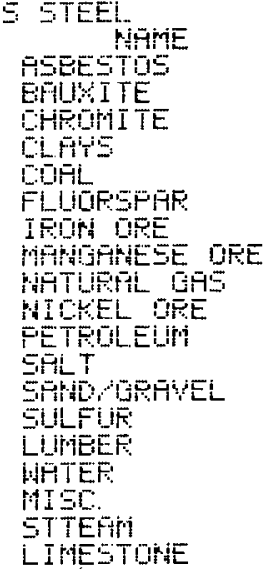 & 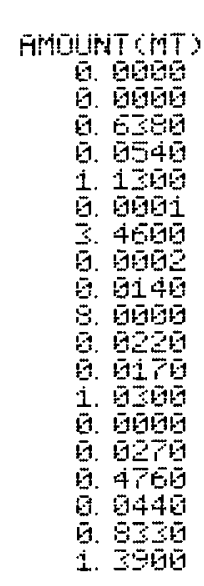 \\
\hline Bult & 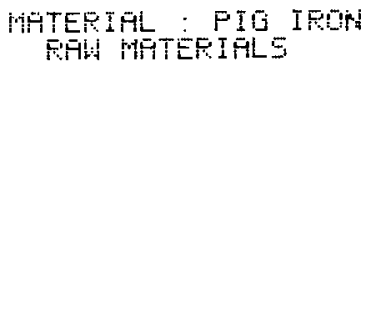 & 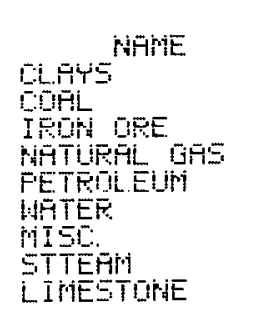 & 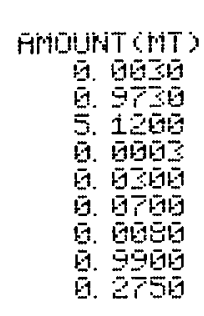 \\
\hline Eubrt & 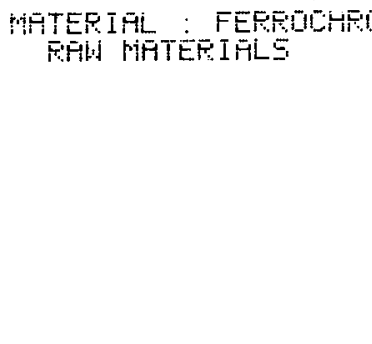 & 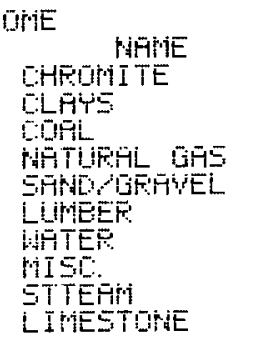 & 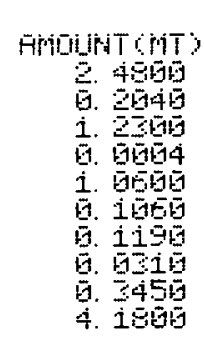 \\
\hline Eilike & $\begin{array}{l}\text { MATEEIFL : LIAEEED } \\
\text { FPW MPTEFIALS }\end{array}$ & $\begin{array}{l}\text { OIL } \\
\text { FLFX SFEO }\end{array}$ & Froyd \\
\hline घ!1 & 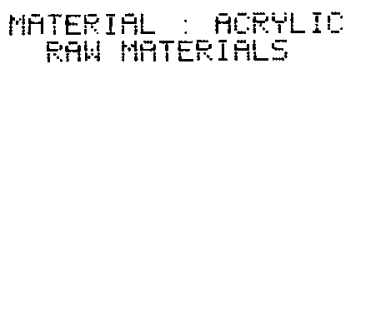 & 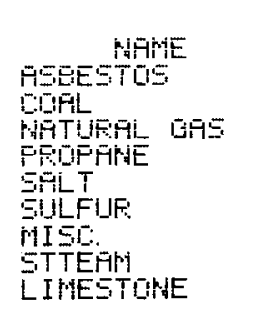 & 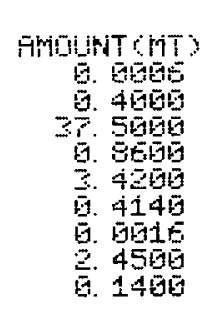 \\
\hline EILLK: & $\begin{array}{l}\text { MATEFIFIL : ALLYO FE } \\
\text { PFIH MHTERIMLS }\end{array}$ & 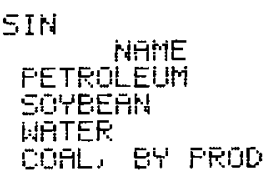 & 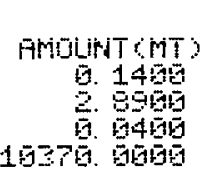 \\
\hline
\end{tabular}


EUIK MATEFIFL : FOLYESTEP RESIM

PEIN MHTERIFLS

NATUETLL GAS

WITTER

COEL, ET FED

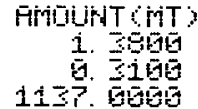

EIULK MFTERIAL : PUL PLFETIE

FAH MATECIALS MUESTTE

COHA

NATHEAT GES

SULT

WITEF

MISE:

STTEFIO

LIHESTORIE

FHDUNTCMT:
E. 8964
1. 5205
6. 609
i. 2010
1. 605
‥ $6 \leq 610$
6. $12=$
i. 3406

EULL MHTEFIFL : RUEEER, SEF REN WATTERIFLS

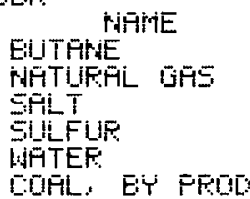

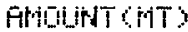

i. $i$ iा 161

ต.

ㅂ. 1 16101

6. 619

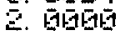

17. Eี

EULK HATEFIFL : STLICONES PAH MATERIFLS

MESESTHE

E:AUU: ITE

BLYS

OOPFË OFE

FLIJOFSTFM

I

MFRIGHRESE QRE

RATUERT GOE

PETRLLEUH

S.TLT

GFMD, GETHEL

SiiLFUF

LURIEEF.

HITTEF

STTEFi

LIMESTORE

BULK MATEEIAL : TEFLDN PHIS MFTERIFLS

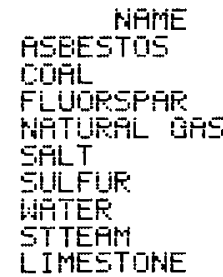

EULKK MATERIAL : NYLON RHW MATERIALE

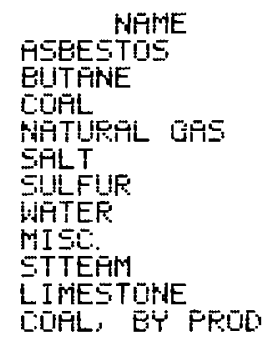

FRIOLNTSMT:

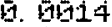

6. ETE15

5. $\overline{1} \overline{1} \overline{1} i$

E. Eดำ

5. องดิ

E. GT.5

9.

เ. 8586

19. 50144

4. 33616

6. 6.6010

G. 199

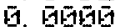

‥ 6435

2. 9450

ज. 26

FMULNT लिT

E. 010

57. 4690

i. 740

‥ 370

E. iEtat

6. 75.96

5. 5.5610

2. 95016

6. 4560

FHOUNT (MT)

6. 5150

ต. $5 \overline{0}$

9. 2465

6. 3201

1. 5796

6. 51920

ษ5. ริธยติ

․ 5119

5. 806

ด. 1300

$44 \overline{1}$. 


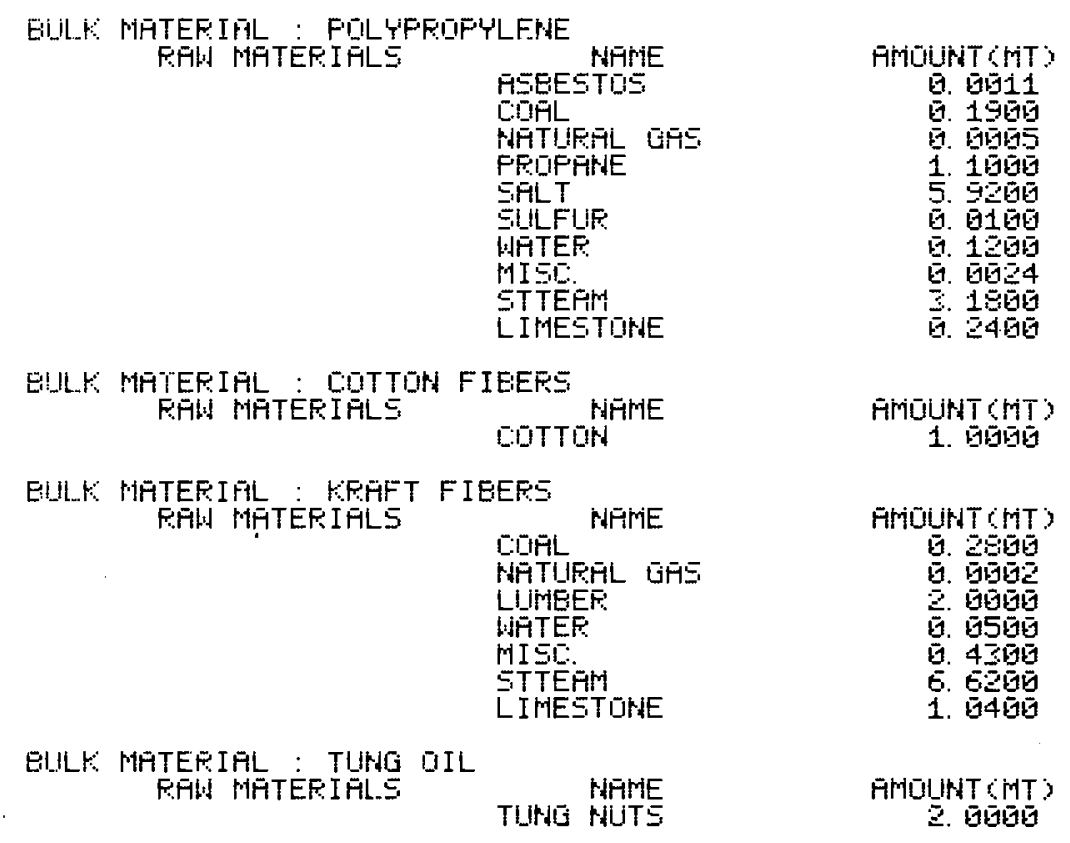




\author{
APPENDIX E \\ Characterization of \\ MIT-LL and UNL PHOTOVOLTAIC SYSTEM \\ at Mead, Nebraska
}

Modified with State-of-the-Art

Silicon n/p Single Crystal Cells at 10\% Efficiency and GaAs MIS Thin Film Cells at 10\% Efficiency 
MIT-LL and UNL Photovoltaic System

at Mead, Nebraska

Modified with State-of-the-Art

Silicon $n / p$ Single Crysta 11 Cells - 10\% Efficiency

This sytem was built by the Massachusetts Institute of Technology's Lincoln Laboratory. The power produced is used to pump water to irrigate 80 acres of corn and soybeans at the University of Nebraska Field Laboratory near Mead.

A total of 28 flat panels, each 8 feet by 25 feet, comprise the array. The units peak power of $25 \mathrm{KW}$ is derived from 240 square meters of silicon operating at $10.4 \%$ efficiency. The state-of-the-art silicon cells use less material than those now in production.

The array output ( 6.2 amps at 150 volts per pane 1 ) is fed to two buildings. One houses system control equipment and three 7.5 kVA inverters. The other building houses 38 large lead-acid storage batteries capable of storing $85 \mathrm{KW}-\mathrm{hr}$. 
MIT-LL ANO UNL FHÜTÖVÖLTÃIC SYSTEH

AT MERD, MEBFASKA

MODIFIED WITH STATE OF THE RRT SILICON MSP

SINGLE CRYSTAL CELLS - 19\% EFFICIENIEY

TECHNIOLOGY :

CAPALITY:

APPLICATION:

LOIL:ATION:

INSOLATI ION:

SOLGR EONATR IBUT ION

SUIPPLEMENT

SOLAR EFFIEIENITY

COLLECTOR HREA:

OFFRAT ING TEMEERATURE

ENEROY TRANSFORT MEOIUM

STORATGE TYPE:

STURAGE CAFACITY

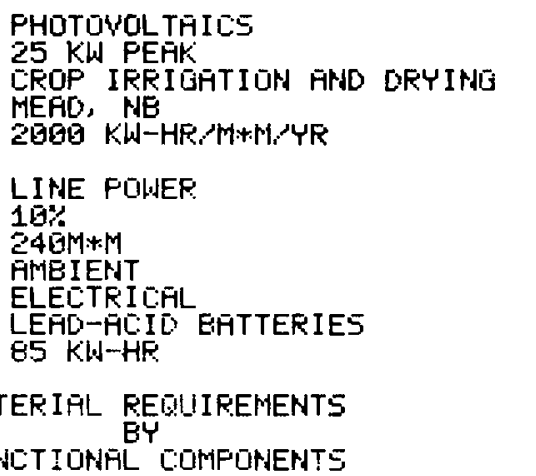

FUNICT TUNAL COMMONENTS

12. ENERḠY CCOLLLECTOR

SIL ICOUNE

KILOGRAMS

12. GQ GLFZINT́

1860.

12. GS ABSOREER - SIN,P SINGLE CRYSTHL 16: EFF ICIENICY ACT IVE LATERS

N-DÜFANT

P-DÜFANTT

ORID C:ONTAC:T

SILICON

FHOSFHOROUS

BuROH

TITANIUM

FALLFIILIN

SILVER

BACK CONTACT

AR COOFITINIS

ALUMINUM

12. 94 ENEREYY TRANSPORT

PFNEL INTERE:ONNECTS

COPPER

TEFL IN

ELECTRIEAL BOXES, NIREWHYS. INSULATURS, ECT

CARBON STEEL

STAINLESS STEEL

COPPER

FLASTICS, LAMINATES

NYTLUN

GLUMINUM

RLIBEER

GE-4E SULLOER

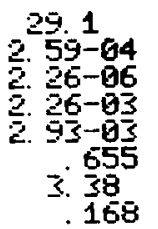

35. $\frac{1}{26}$

1325.

$5 ? 2$.

51

15. 3

$\frac{6}{6}$

12. G7 FRANHE

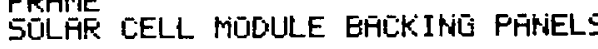

FRP FÜLYESTER

1 도을.

ALUMINUM

1146

12. 09 SLPPGRTS

G061 FLUMINUM

STAINLESS STEEL

CUNCRETE

FRAMEWORK

6061 FLUMINUM

STAINLESS STEEL

CHREON STEEL

2240.

260.

1. $162+95$

1. $17+54$

446.

240 
13. ERERIJY TRANGFORT

KILOGRAMS

13. 62 ELECTRICAL WIRE

COAPFER

24.

13. 65 SUPRORTS

CONCUIT

CONDUIT SERLS

FLUMINUM

CAREBUN STEEL

RUBBER

909.

2. 90

\section{ENERGY CONVERSION*}

15. ENERḠYY STÜRATIGE

15. 61 MISCELLRNEOUS

BATTERT BUILDING 19FT $\times$ 2EFT

BATTERYY COVERS

BATTERY INTERCONNECTS

CAREINN STEEL

CONACRETE

FIBER'iLĀSS WOŌL

FLYWOOD-SÖFT WŪ̄D

ACRYL IC

COPPER

PHENOLLIC

MICARTA

EPOXY

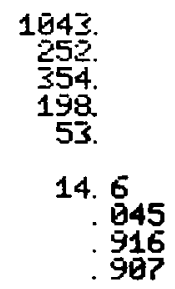

15. G2 PRIMARY STORAGE

38 BATTERIES, IPS AMF-MR RT 5 WÖLTS

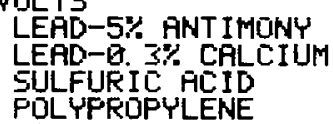

119 ?

1438

206

15. G4 SUPPORT

STAINLESS STEEL

$3 \overline{6} 6$.

CARBÜ STEEL

16. ENERGY CONITIONINGO

16. 02 INYERTER

ENCLOSURE

CORES, WINDINGS

INSULATION

INSTRUHENTRTION

SILICUN CONTROLLEO RECTIFIERS

CRRBON STEEL
CARBON STEEL

COPPER

SILICON STEEL

VARNISH

PHENOL IC

COPPER

ZINC:

QLASS-SUDA LIME

COPFER

SILICON

ELECTRICAL PORCELAIN
$1 \mathrm{GE}$.

34. 0

$15 \overline{.}$

17.

5. 89

4. 98

1. 36

. 68

5. 1

.$\frac{11}{34}$

* Not Applicable to this Design. 
17. ENERIOY SYSTEMS CONATROLLER

KILOGRAMS

17. E1 MISCELLFNEOUSE EUILDING 15FT $x$ 25FT

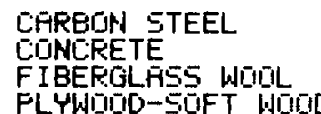

1497

544.

544.

17. G2 METERS, SWITLHES, RELAYS, TERMINAL BOARDS, ETL COPPER ERREON STEEL PHENIILIC

STRINLESS STEEL

29.5

5 1. 8

64.4

17. GE SUPFORTS - CHBINETS, ETE

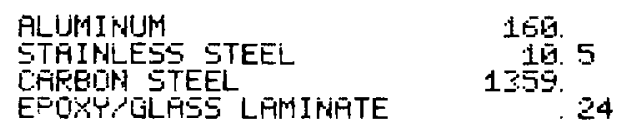




\author{
MIT-LL and UNL Photovoltaic System \\ at Mead, Nebraska \\ GaAs-MIS Thin Film Cell Modification \\ State-of-the-Art Ce11s at 10\% Efficiency
}

\begin{abstract}
A geometric packing factor of 0.8 is assumed for this GaAs cell, which reduces the total number of 8-foot by 25-foot panels from 28 to 17 . The unit's peak power of $25 \mathrm{KW}$ is derived from 250 square meters of GaAsMIS Thin Film Cells operating at 10\% efficiency.

The array output ( 6.2 amps at 150 volts per panel) is fed to two buildings. One houses system control equipment and three $7.5 \mathrm{kVA}$ inverters. The other building houses 38 large lead-acid storage batteries capable of storing $85 \mathrm{KW}-\mathrm{hr}$.

This sytem was built by the Massachusetts Institute of Technology's Lincoln Laboratory. The power produced is used to pump water to irrigate 80 acres of corn and soybeans at the University of Nebraska Field Laboratory near Mead.
\end{abstract}




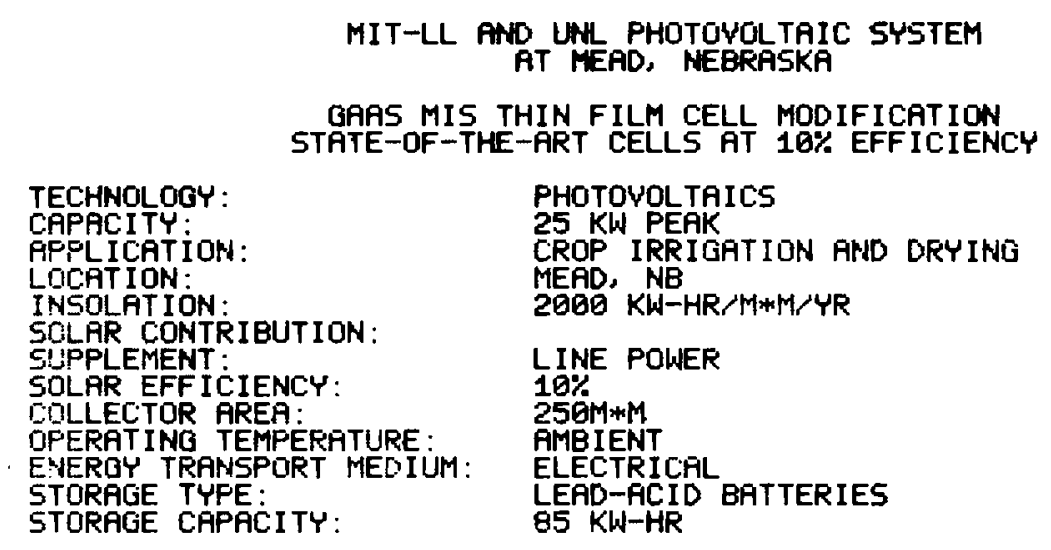

12. ENERGY COLLECTOR

12. 62 GLAZING

SODA LIME GLRSS

KILOGRAMS

12. 03 ABSOREER-GAAS MIS THIN FILM 10\% EFF ICIENCY ACTIVE REGION

N-DOPANT

EPITAXY LATER

BARRIER LAYER
ORID ELECTRODE

BACK CONTACT

AR COFTING

MIS THIN FILM

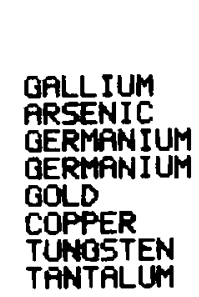

2446.

12. 04 ENERGY TRANSPORT

12. 04 ENERGY TRANSPORT PANEL INTERCONNECTS

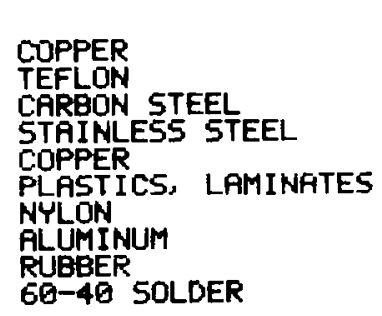

1. 28

4. $0-6$ ?

6. 65

550

4. 112

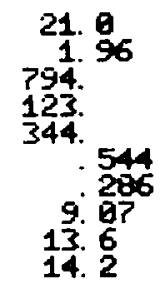

12. 67 FRPIME

SOLAR CELL BACKINO PANEL

CARBON STEEL

748.

12. Q9 SUPFORTS
UPRIGHTS

FRAMEWORK

\section{ALUMINUM STAINLESS STEEL CONCRETE}

6061 RLLMINUM STAINLESS STEEL CARBON STEEL
1350

124

6. $\overline{3} 30+\theta$

วิธียั.

268. 
PNL-2711

UC-63

\section{DISTRIBUTION}

No. of

Copies

OFFSITE

1 A. A. Churm

DOE Patent Division

9300 S. Cass Avenue

Argonne, IL 60439

100 Fred Koomanoff, Director

Space Power Systems Project

office

Office of Energy Research

Department of Energy

Washington, D. C. 20545

David Hack

Congressional Research

Service

U.S. Library of Congress

Washington, D. C. 20540

Frankl in Hudd le

U.S. Library of Congress

Washington, D. C. 20540

Dr. Hebert Newkirk

Lawrence Livermore Laboratory

$M-790$

P. 0. Box 808

Livermore, CA 94550

Bill Bradley

Burns \& Rowe

185 Crossways Park Drive

Woodbury, N. Y. 11797

Dr. Atsuyuki Suzuki

Department of Nuclear Engineering

Faculty of Engineering

University of Tokyo

Hongo, Tokyo 113

JAPAN
No. of

Copies

John Mitchener

Organization 5721

Box 5800

Sandia Laboratories

Albuquerque, N.M. 87185

Vince Gutschick

Los Alamos Scientific Laboratory

Mai1 Stop 547

P. 0. Box 1663

Los Alamos, N.M. 87545

Lisa Frantzis

South Street

Middlebury, CT. 06762

Neil H. Wheeler, Jr.

Market Research Analyst

Martin Marietta Aluminum

6801 Rockledge Drive

Bethesda, MD. 20034

T. P. Brody

Program Manager

Westinghouse Electric Corp.

Research and Development Center

1310 Beulah Road

Pittsburgh, PA 15235

Dr. John D. Meakin

Associate Director

Institute of Energy Conversion

University of Delaware

Newark, Delaware 19711

James O. Martin, P.E.

2017 N. 11th Street

Phoenix, AZ 85006

James Burrows, President

Charles River Associates

1050 Massachusetts Avenue

Cambridge, MA 02138 
No. of

Copies

\author{
W. L. Swager \\ Battel le-Columbus \\ 505 King Avenue \\ Columbus, $\mathrm{OH} 43201$ \\ Dr. J.C. Grosskruitz \\ SERI \\ Golden, C0 80401 \\ Dennis Horgan \\ SERI \\ Golden, C0 80401 \\ Ken 01sen \\ SERI \\ Golden, CO 80401 \\ Alvin Alm \\ Policy \& Evaluation \\ Department of Energy \\ 17 th \& Pennsylvania \\ Washington, D.C. 20461 \\ Frederick J. Weinhold \\ Policy \& Evaluation \\ Department of Energy \\ 734 Jackson Place, NW \\ Washington, D.C. 20006 \\ David R. Israel \\ Office of Energy Research \\ Department of Energy \\ 20 Massachusetts Avenue \\ Washington, D.C. 20545 \\ Roger W. LeGassie \\ Office of Energy Research \\ Department of Energy \\ 20 Massachusetts Avenue \\ Washington, D.C. 20545 \\ Joel Snow \\ Office of Energy Research \\ Department of Energy \\ 20 Massachusetts Avenue \\ Washington, D. C. 20545
}

No. of

Copies

Dr. George Y. Jordy

Office of Policy \& Evaluation

Department of Energy

20 Massachusetts Avenue

Washington, D. C. 20545

Eric H. Willis

Office of Intergovernmental

\& Institutional Relations

Department of Energy

20 Massachusetts Avenue

Washington, D. C. 20545

George Fumich

Office of Energy Technology

Department of Energy

20 Massachusetts Avenue

Washington, D. C. 20545

Gerald W. Braun

Office of Energy Technology

Department of Energy

20 Massachusetts Avenue

Washington, D. C. 20545

Barbara K. Bowers

Department of Energy

Mail Stop E-201

Washington, D. C. 20545

Dr. H. H. Marvin

Office of Energy Technology

Department of Energy

20 Massachusetts Avenue

Washington, D. C. 20545

Martin U. Gutstein

Office of Energy Technology

Department of Energy

Bicentennial Bldg.

600 E Street, N.W.

Washington, D. C. 20004 
No. of

Copies

James E. Rannels

Office of Energy Technology

Department of Energy

20 Massachusetts Avenue

Washington, D.C. 20545

Paul D. Maycock

Office of Energy Technology

Department of Energy

Bicentennial Building

600 E Street, NW.

Washington, D.C. 20004

Dr. Morton B. Prince

Office of Energy Technology

Department of Energy

Bicentennial Building

600 E Street, NW

Washington, D. C. 20004

Donald A. Feucht

Office of Energy Technology

Department of Energy

Bicentennial Building

600 E. Street, NW

Washington, D.C. 20004

Louis V. Divone

Office of Energy Technology

Department of Energy

Bicentennial Building

600 E Street, NW

Washington, D.C. 20004

Sigmund Gronich

Office of Energy Technology

Department of Energy

Bicentennial Building

600 E Street, NW

Washington, D.C. 20004

Dr. R. F. Ward

Office of Energy Technology

Department of Energy

Bicentennial Building

600 E Street, NW

Washington, D. C. 20004
No. of

Copies

Raymond H. Fields

Office of Energy Technology

Department of Energy

20 Massachusetts Avenue

Washington, D. C. 20545

Donald A. Beattie

Office of Conservation \& Solar Application

Department of Energy

20 Massachusetts Avenue

Washington, D. C. 20545

Dr. Maxine Savitz

Office of Conservation \&

Solar Application

Department of Energy

20 Massachusetts Avenue

Washington, D.C. 20545

Ronald D. Scott

Office of Conservation \&

Solar Application

Department of Energy

20 Massachusetts Avenue

Washington, D.C. 20545

Dr. James L. Liverman

Department of Energy

Mai] Stop 6128

20 Massachusetts Avenue

Washington, D. C. 20545

Joan Hock

Office of Conservation \&

Solar Application

Department of Energy

20 Massachusetts Avenue

Washington, D.C. 20545

Dario M. Monti

Department of Energy

20 Massachusetts Avenue

Washington, D. C. 20545 
No. of

Copies

Dr. Peter House

Department of Energy

20 Massachusetts Avenue

Washington, D. C. 20545

Dr. Nathanial F. Barr

Department of Energy

Germantown, MD

John Cummins

Electric Power Research

Institute

P. 0. Box 10412

Palo Alto, CA 94303

Bill Adolfson

Booz Allen \& Hamilton

135 S. La Salle

Chicago, IL 60603

Dr. Len Weiss

Room 204

Russel Senate Office Bldg.

Washington, D. C. 20510

James $P$. Junk

485001 ive Street

Denver, CO 80022

Jonathan White

KTA Corporation

12300 Washington Ave.

Rockville, MD 20852

Bruce Rodin

Ecosol Ltd.

2 West 59th Street

New York, NY 10019

George W. Eldridge

American Heliothermal Corp.

2625 S. Santa Fe Drive

Denver, CO 80223

Edward Jones

Sunworks

P. 0. Box 1004

New Haven, CO
No. of

Copies

Hugo Byers

Raypak, Inc.

P. 0. Box 5790

Westlake Village, CA 91359

Alan B. Casamajor

Lawrence Livermore Laboratory

P. 0. Box 808

Livermore, CA 94550

S. James Robertson

Lockheed Missles Space Co., Inc.

Huntsville Research \& Engineering Center

4800 Bradford Drive

Huntsville, AL 35807

Charles H. Franke

Chamberlain Manufacturing Corp.

845 Larch Avenue

Elmhurst, IL 60126

David A. Byfield

Honeywell Inc.

2600 Ridgeway Parkway

Minneapolis, MN 55413

Charles Guttman

Mai 1 Code PSO 1

Marshall Space Flight Center

Huntsville, AL 35812

Harold E. Benson

Lyndon B. Johnson Space Center

Houston, TX 77058

R. L. Bell

Varian Associates

611 Hansen Way

Palo Alto, CA 94303

Margaret R. White

Building 29

Lawrence Berkeley Laboratory

Berkeley, CA 94720 
No. of

Copies

A1 Shaheen

SERI

1536 Cole Blvd.

Golden, C0 80401

W. R. Romaine

MIT-Lincoln Laboratory

P. 0 . Box 73

Lexington, MA 02173

Jimmie Q. Searcy

Environmental Research

Division 5333

Sandia Laboratories

A1buquerque, NM 87185

Clifford Coulbert

Jet Propulsion Laboratory

4800 0akgrove Drive

Pasadena, CA 91103

R. C. Hodge

General Electric Co.

P. 0. Box 8555

Philadelphia, PA 19101

E. L. Burgess

Sandia Laboratories

Division 5719

Albuquerque, NM 87115

27 DOE Technical Information Center

\section{ONSITE}

DOE Richland Operations

Office

$$
\begin{aligned}
& \text { G.L. Liffick } \\
& \text { H.E. Ransom }
\end{aligned}
$$

No. of

Copies

Pacific Northwest Laboratory

G.S. Allison

T.W. Ambrose

C.H. Bloomster

N.E. Carter

T.D. Chickalla

M. Clement

T.B. Correy

S.D. Dahlgreen

D.K. Davis

R.L. Dillon

K. Drumheller

L.L. Fassbender

H.D. Freeman

H.R. Gardner

R.F. Geisendorfer

W.E. Gurwe11 (20)

C.R. Hahn

T.P. Harrington

J.N. Hartley (20)

H. Harty

M. Hazilla

E.R. Hil1

A.B. Johnson, Jr.

K.E. Keene

R.S. Kemper

J.C. King

R.R. King

J.W. Litchfield

R.P. Marshal1

R.D. Nelson

W.T. Pawlewicz

C.A. Rohrmann

S.A. Smith

J.0. Vining

R.L. Watts (20)

Technical Information Files (5)

Publishing Coordination (2) 

. 